Nevada

Environmental

Restoration

Project

\title{
Closure Report for Corrective Action Unit 528: Polychlorinated Biphenyls Contamination Nevada Test Site, Nevada
}

Controlled Copy No::

Revision: 0

September 2006

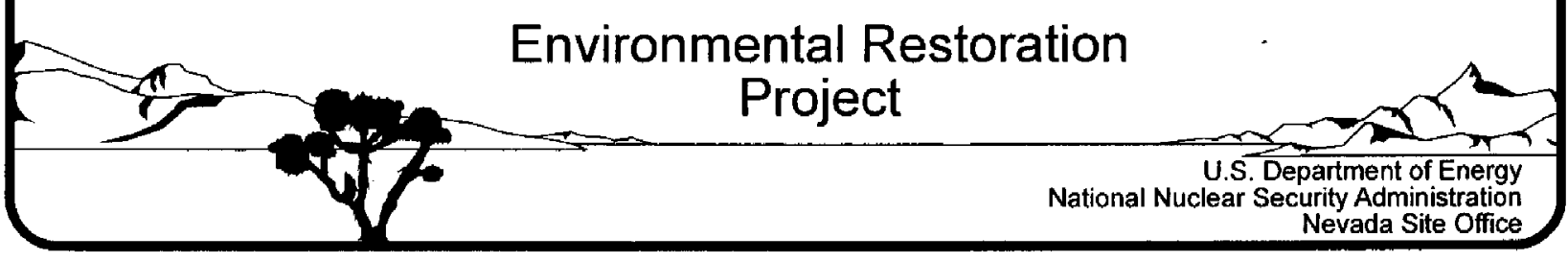




\section{DISCLAIMER}

Reference herein to any specific commercial product, process, or service by trade name, trademark, manufacturer, or otherwise, does not necessarily constitute or imply its endorsement, recommendation, or favoring by the United States Government or any agency thereof or its contractors or subcontractors.

This report has been reproduced directly from the best available copy.

Available for sale to the public from:

U.S. Department of Commerce

National Technical Information Service

5285 Port Royal Road

Springfield, VA 22161-0002

Telephone: (800) 553-6847

Fax: (703) 605-6900

E-mail: orders@ntis.gov

Online ordering: http://www.ntis.gov/ordering.htm

Available electronically at http://www.osti.gov/bridge.

Available for a processing fee to the U.S. Department of Energy and its contractors, in paper, from:

U.S. Department of Energy

Office of Scientific and Technical Information

P.O. Box 62

Oak Ridge, TN 37831-0062

Telephone: (865) 576-8401

Fax: (865) 576-5728

E-mail: reports@adonis.osti.gov 


\title{
CLOSURE REPORT FOR CORRECTIVE ACTION UNIT 528: POLYCHLORINATED BIPHENYLS CONTAMINATION NEVADA TEST SITE, NEVADA
}

\author{
U.S. Department of Energy \\ National Nuclear Security Administration \\ Nevada Site Office \\ Las Vegas, Nevada
}

Controlled Copy No.

Revision: 0

September 2006 
THIS PAGE INTENTIONALLY LEFT BLANK 


\section{CLOSURE REPORT FOR CORRECTIVE ACTION UNIT 528: POLYCHLORINATED BIPHENYLS CONTAMINATION NEVADA TEST SITE, NEVADA}

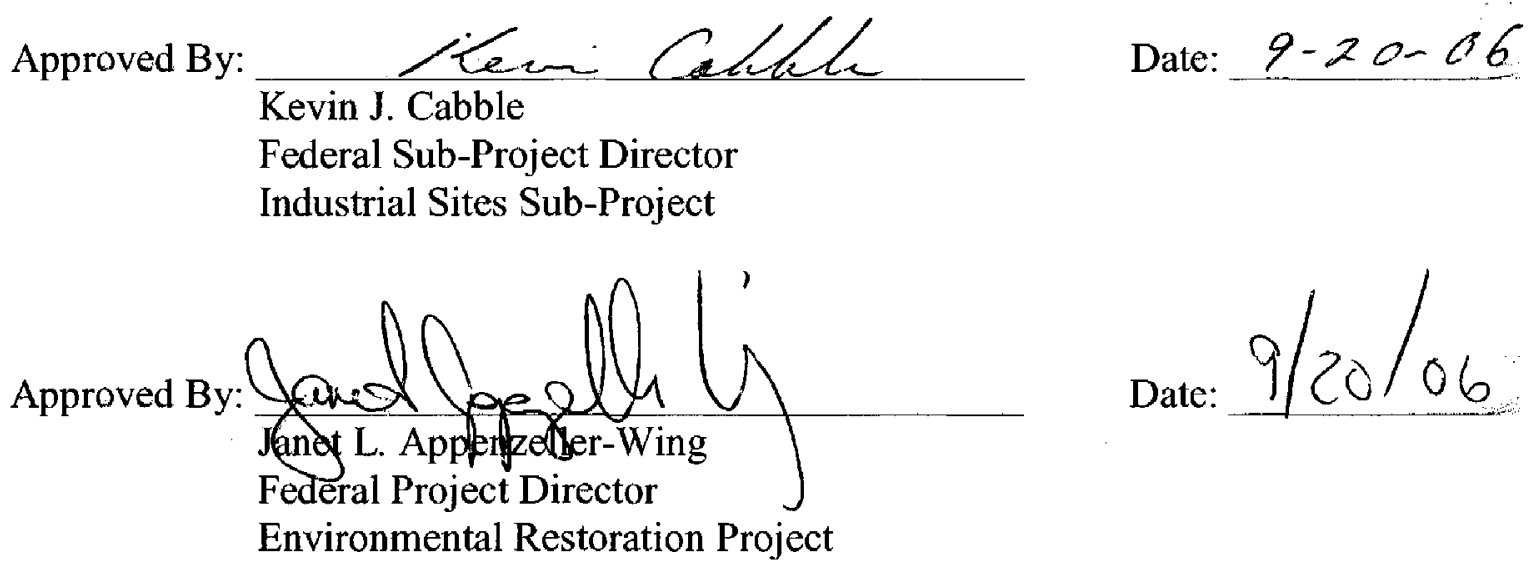


THIS PAGE INTENTIONALLY LEFT BLANK 


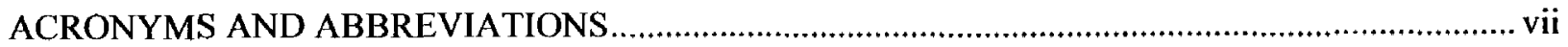

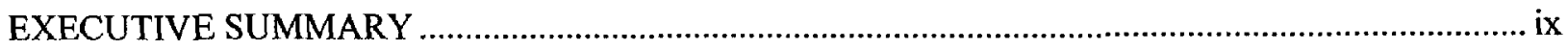

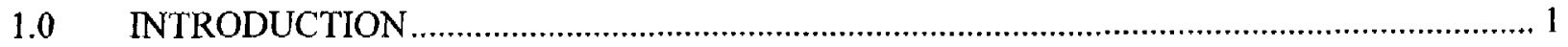

1.1 PURPOSE

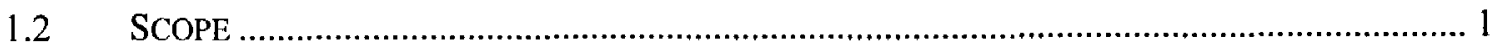

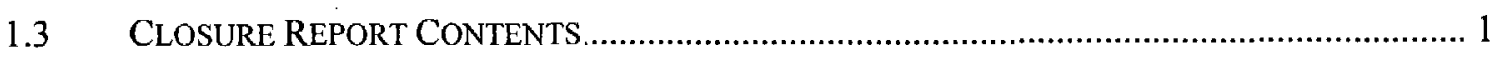

1.3.1 Data Quality Objectives ......................................................................... 3

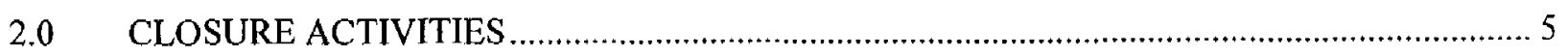

2.1 DESCRIPTION OF CORRECTIVE ACTION ACTIVITIES .............................................. 5

2.1.1 Preplanning and Site Preparation ............................................................. 5

2.1.2 Excavation of Impacted Soil .................................................................... 5

2.1.3 Collection of Verification Soil Samples............................................................ 5

2.1.4 Implementation of Use Restrictions .............................................................. 5

2.1.5 Transport and Disposal of Excavated Soil .................................................... 8

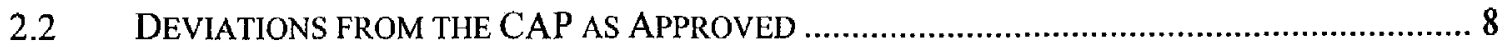

2.3 CORRECTIVE ACTION SCHEDULE AS COMPLETED ................................................... 8

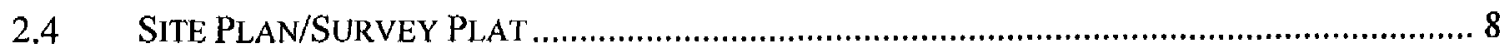

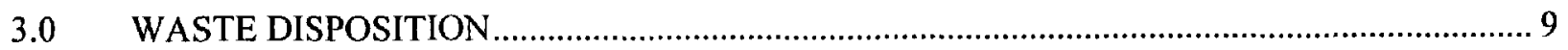

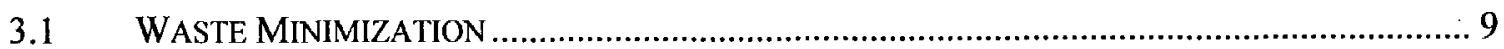

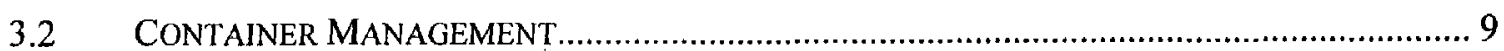

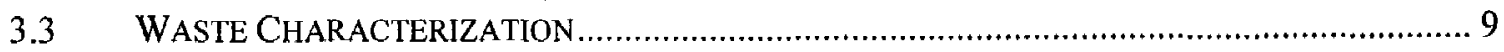

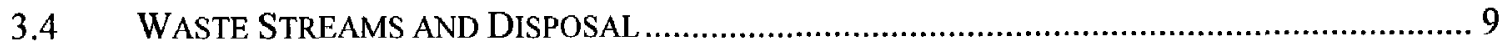

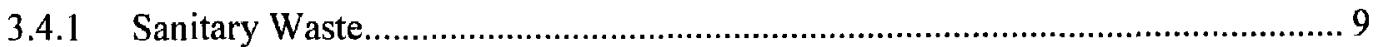

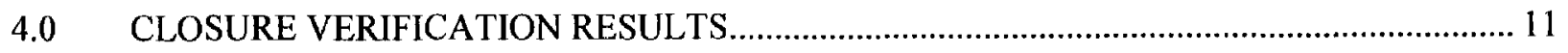

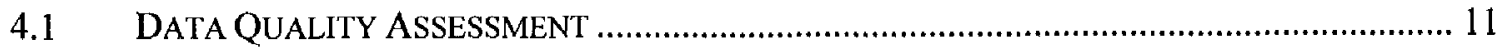

4.1.1 Quality Assurance/Quality Control Procedures .............................................. 11

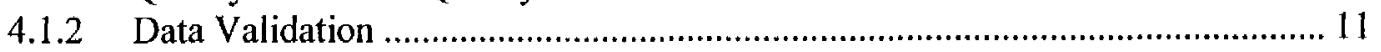

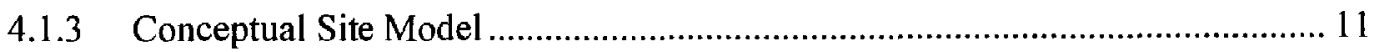

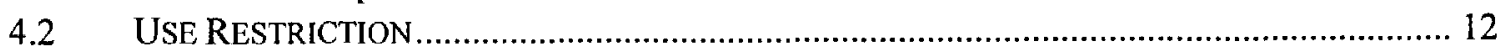

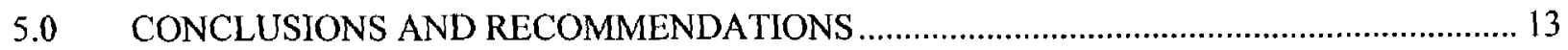

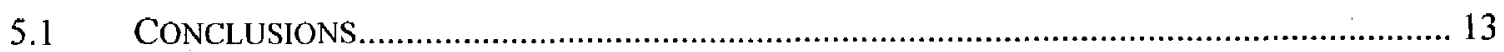

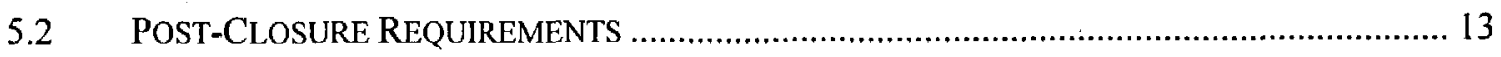

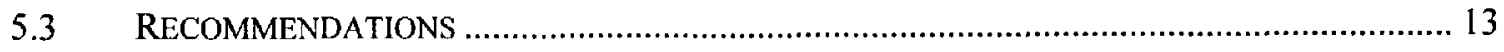

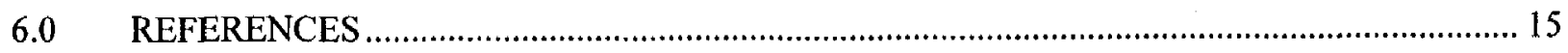

LIBRARY DISTRIBUTION LIST 


\section{FIGURES}

FigURE 1. CAU 528 SITE Location MAP ........................................................................ 2

FigURE 2. CAS 25-27-03 VERIFICATION SAMPLE LOCATIONS .............................................. 6

Figure 3. CAS 25-27-03 USE RESTRICTION BOUNDARIES ................................................ 7

\section{TABLES}

Table 1. CAU 528 Closure Activities Schedule ........................................................... 8

Table 2. CaU 528 Waste Characterization Sample Results.......................................... 10

TABLE 3. CAU 528 SoIL VERIFICATION SAMPLE RESULTS.................................................... 12

\section{APPENDICES}

APPENDIX A - DATA QUALITY OBJECTIVES

APPENDIX B - SAMPLE ANALYTICAL RESULTS

APPENDIX C - WASTE DisPositION DOCUMENTATION

APPENDIX D - USE RESTRICTION DOCUMENTATION

APPENDiX E - Site Closure Photographs 


\section{ACRONYMS AND ABBREVIATIONS}

$\begin{array}{ll}\text { bgs } & \text { below ground surface } \\ \text { BN } & \text { Bechtel Nevada } \\ \text { CAI } & \text { Corrective Action Investigation } \\ \text { CAIP } & \text { Corrective Action Investigation Plan } \\ \text { CAP } & \text { Corrective Action Plan } \\ \text { CAS } & \text { Corrective Action Site } \\ \text { CAU } & \text { Corrective Action Unit } \\ \text { COC } & \text { contaminant of concern } \\ \text { COPC } & \text { contaminant of potential concern } \\ \text { CR } & \text { Closure Report } \\ \text { CSM } & \text { conceptual site model } \\ \text { DOE/NV } & \text { U.S. Department of Energy, Nevada Operations Office } \\ \text { DQI } & \text { data quality indicator } \\ \text { DQO } & \text { data quality objective } \\ \text { DRO } & \text { diesel-range organics } \\ \text { EPA } & \text { U.S. Environmental Protection Agency } \\ \text { FFACO } & \text { Federal Facility Agreement and Consent Order } \\ \text { FSR } & \text { field-screening results } \\ \text { ft } & \text { foot (feet) } \\ \text { GRO } & \text { gasoline-range organics } \\ \text { IDW } & \text { investigation-derived waste } \\ \text { LASL } & \text { Los Alamos Scientific Laboratory } \\ \text { Ng/kg } & \text { microgram(s) per kilogram } \\ \text { mg/kg } & \text { milligram(s) per kilogram } \\ \text { NAC } & \text { milligram(s) per liter } \\ \text { minimum reporting limit } \\ \text { Nevada Administrative Code }\end{array}$




\section{ACRONYMS AND ABBREVIATIONS (continued)}

NNSA/NSO U.S. Department of Energy, National Nuclear Security Administration Nevada Site Office

NNSA/NV U.S. Department of Energy, National Nuclear Security Administration Nevada Operations Office

NTS Nevada Test Site

PA preliminary assessment

PAL preliminary action level

PCBs polychlorinated biphenyls

ppm part(s) per million

PRG preliminary remediation goal

QA quality assurance

QAPP Quality Assurance Project Plan

QC quality control

RCRA Resource Conservation and Recovery Act

SAIC Science Applications International Corporation

SVOC semivolatile organic compound

TCC Test Cell C

TCLP Toxicity Characterization Leaching Procedure

TPH total petroleum hydrocarbons

TSCA Toxic Substances Control Act

UR Use Restriction

VOC volatile organic compound

$\mathrm{yd}^{3} \quad$ cubic yard(s) 
Corrective Action Unit (CAU) 528 is identified in the Federal Facility Agreement and Consent Order (FFACO) of 1996 as Polychlorinated Biphenyls Contamination (FFACO, 1996). CAU 528 is located in Area 25 of the Nevada Test Site and consists of one Corrective Action Site (CAS), CAS 25-27-03, Polychlorinated Biphenyls Surface Contamination.

CAU 528 closure activities were conducted from May 2006 to July 2006 according to the FFACO and the Nevada Division of Environmental Protection-approved Corrective Action Plan for CAU 528 (U.S. Department of Energy, National Nuclear Security Administration Nevada Site Office, 2005). The approved corrective action alternative was closure in place with administrative controls. All waste generated during the closure of CAU 528 was appropriately managed and disposed.

CAS 25-27-03 consists of 12 areas impacted with total petroleum hydrocarbons and/or polychlorinated biphenyls (PCBs). At Areas 1 through 6 and Areas 8 through 12, use restriction (UR) warning signs were posted around the perimeter of the impacted areas and URs were implemented. The "CAU Land-Use Restriction Information" form and a figure showing the locations of the surveyed points delineating the use-restricted areas are included in Appendix D of this report. At Area 7, a total of approximately 9.5 cubic yards of soil impacted with PCBs above the Toxic Substances Control Act action level of 25 milligrams per kilogram (mg/kg) was excavated, stored in B-25 boxes, and disposed at the Area 9 U10c Landfill. Waste disposition documentation is included in Appendix $\mathrm{C}$ of this report. Soil samples were collected to verify that PCB concentrations in the remaining soil were less than $25 \mathrm{mg} / \mathrm{kg}$. A summary of the soil sample results is included as Appendix B of this report. Area 7 lies within the boundary of Area 11; therefore, remaining soil within Area 7 impacted with PCBs below $25 \mathrm{mg} / \mathrm{kg}$ lies within the Area 11 UR boundary. 
Closure Report - CAU 528

Section: Executive Summary

Revision: 0

Date: September 2006

\section{THIS PAGE INTENTIONALLY LEFT BLANK}


Corrective Action Unit (CAU) 528 is identified in the Federal Facility Agreement and Consent Order (FFACO) of 1996 as Polychlorinated Biphenyls Contamination (FFACO, 1996).

CAU 528 is located in Area 25 of the Nevada Test Site (NTS) (Figure 1) and consists of one Corrective Action Site (CAS), CAS 25-27-03, Polychlorinated Biphenyls Surface Contamination.

\subsection{Purpose}

This Closure Report (CR) describes the closure activities performed at CAU 528, Polychlorinated Biphenyls Contamination, as presented in the Nevada Division of Environmental Protection (NDEP)-approved Corrective Action Plan (CAP) (U.S. Department of Energy, National Nuclear Security Administration Nevada Site Office [NNSA/NSO], 2005). The approved closure alternative was closure in place with administrative controls. This CR provides a summary of the completed closure activities, documentation of waste disposal, and analytical data to confirm that the remediation goals were met.

\subsection{SCOPE}

Previous site characterization work completed in 2003-2004 found soil containing total petroleum hydrocarbons (TPH) at concentrations greater than the action level of 100 milligrams per kilogram $(\mathrm{mg} / \mathrm{kg})$ and/or polychlorinated biphenyls (PCBs) at concentrations greater than the action level of $1 \mathrm{mg} / \mathrm{kg}$ at 12 areas within CAS 25-27-03 (NNSA/NSO, 2004). The objective of the closure activities was to close the site by posting Use Restriction (UR) warning signs and implementing URs for the 12 areas and excavating and disposing of soil within Area 7 containing PCBs at concentrations greater than the Toxic Substances Control Act (TSCA) action level of $25 \mathrm{mg} / \mathrm{kg}$.

\subsection{Closure Report Contents}

This CR includes the following sections:

- Section 1.0 - Introduction

- Section 2.0 - Closure Activities

- Section 3.0 - Waste Disposition

- Section 4.0 - Closure Verification Results

- Section 5.0 - Conclusions and Recommendations

- Section 6.0 - References

- Appendix A - Data Quality Objectives

- Appendix B - Sample Analytical Results

- Appendix C - Waste Disposition Documentation 


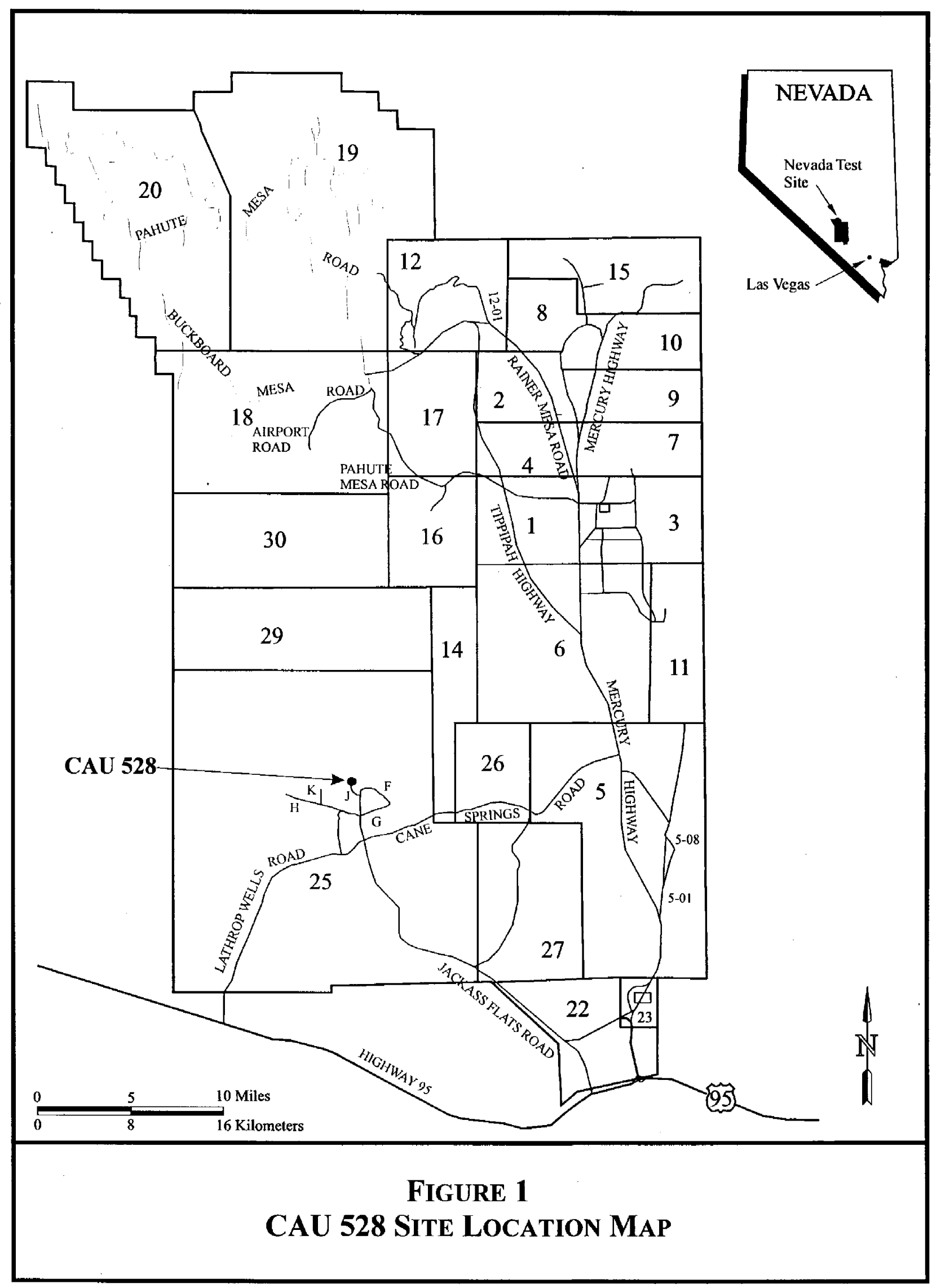


- Appendix D - Use Restriction Documentation

- Appendix E - Site Closure Photographs

- Library Distribution List

This report was developed using information and guidance from the following documents:

- CAP for CAU 528 (NNSA/NSO, 2005)

- Industrial Sites Quality Assurance Project Plan (QAPP) (U.S. Department of Energy, National Nuclear Security Administration Nevada Operations Office [NNSA/NV], 2002)

\subsubsection{Data Quality Objectives}

The data quality objectives (DQOs) used for the closure of CAU 528 were presented in the Corrective Action Investigation Plan (CAIP) (NNSA/NSO, 2003) and are included as Appendix A of this report.

A single conceptual site model (CSM) was developed and presented in the approved CAIP (NNSA/NSO, 2003). The CSM was based on historical documentation and previous analytical results that indicate that PCBs are present in the surface and shallow subsurface. The two suspected sources of contamination are leaking transformers and dust suppression activities conducted throughout the area.

The CSM was found to be consistent with the actual site conditions. Soil samples met the data requirements identified in the DQOs, and the primary CSM was confirmed. 
Closure Report - CAU 528

Section: Introduction

Revision: 0

Date: September 2006

\section{THIS PAGE INTENTIONALLY LEFT BLANK}


This section details the specific closure activities completed during the closure of CAU 528, approved deviations from the CAP, the schedule of completed activities, and the final site plan.

\subsection{DESCRIPTION OF CORRECTIVE ACTION ACTIVITIES}

Closure activities were conducted from May 2006 through July 2006. The following sections detail the activities completed during the closure of CAU 528. Photographs in Appendix E of this report document the site conditions before and after corrective actions were implemented.

\subsubsection{Preplanning and Site Preparation}

Closure activities for CAU 528 were completed using the NDEP-approved CAP

(NNSA/NSO, 2005). Prior to site closure activities, the following documents were prepared:

- National Environmental Policy Act Checklist

- Site-Specific Health and Safety Plan

- Field Management Plan

- NNSA/NSO Real Estate/Operations Permit

- Work control packages

- Sampling and Analysis Plan

\subsubsection{Excavation of Impacted Soil}

A total of approximately 9.5 cubic yards $\left(\mathrm{yd}^{3}\right)$ of soil impacted with PCBs above the TSCA action level of $25 \mathrm{mg} / \mathrm{kg}$ was excavated from two locations in Area 7 (Area 7A and Area 7B) and packaged in $\mathrm{B} 25$ boxes. To access the impacted soil at Area 7B, a small concrete pad was removed and disposed as sanitary waste at the Area 9 U10c Sanitary Landfill. The excavated soil was sampled, and the sample results showed that the concentration of PCBs in the waste was less than the NTS Area 9 U10c Sanitary Landfill waste acceptance limit of $50 \mathrm{mg} / \mathrm{kg}$. Therefore, the soil was disposed as sanitary waste at the Area 9 U10c Sanitary Landfill.

\subsubsection{Collection of Verification Soil Samples}

After the impacted soil was removed, soil verification samples were collected from the two excavations. The sample results verified that the concentration of PCBs in the remaining soil was below the TSCA action level of $25 \mathrm{mg} / \mathrm{kg}$, and the areas were backfilled. Figure 2 shows the verification sample locations.

\subsubsection{Implementation of Use Restrictions}

Soil containing concentrations of PCBs above $1 \mathrm{mg} / \mathrm{kg}$ and $/$ or TPH above $100 \mathrm{mg} / \mathrm{kg}$ was closed in place with administrative controls. UR warning signs were installed around the perimeters of the impacted soil at Areas 1 through 6 and Areas 8 through 12, and URs were implemented. Area 7 lies within the Area 11 UR boundary. Figure 3 shows the boundaries of the UR areas. 


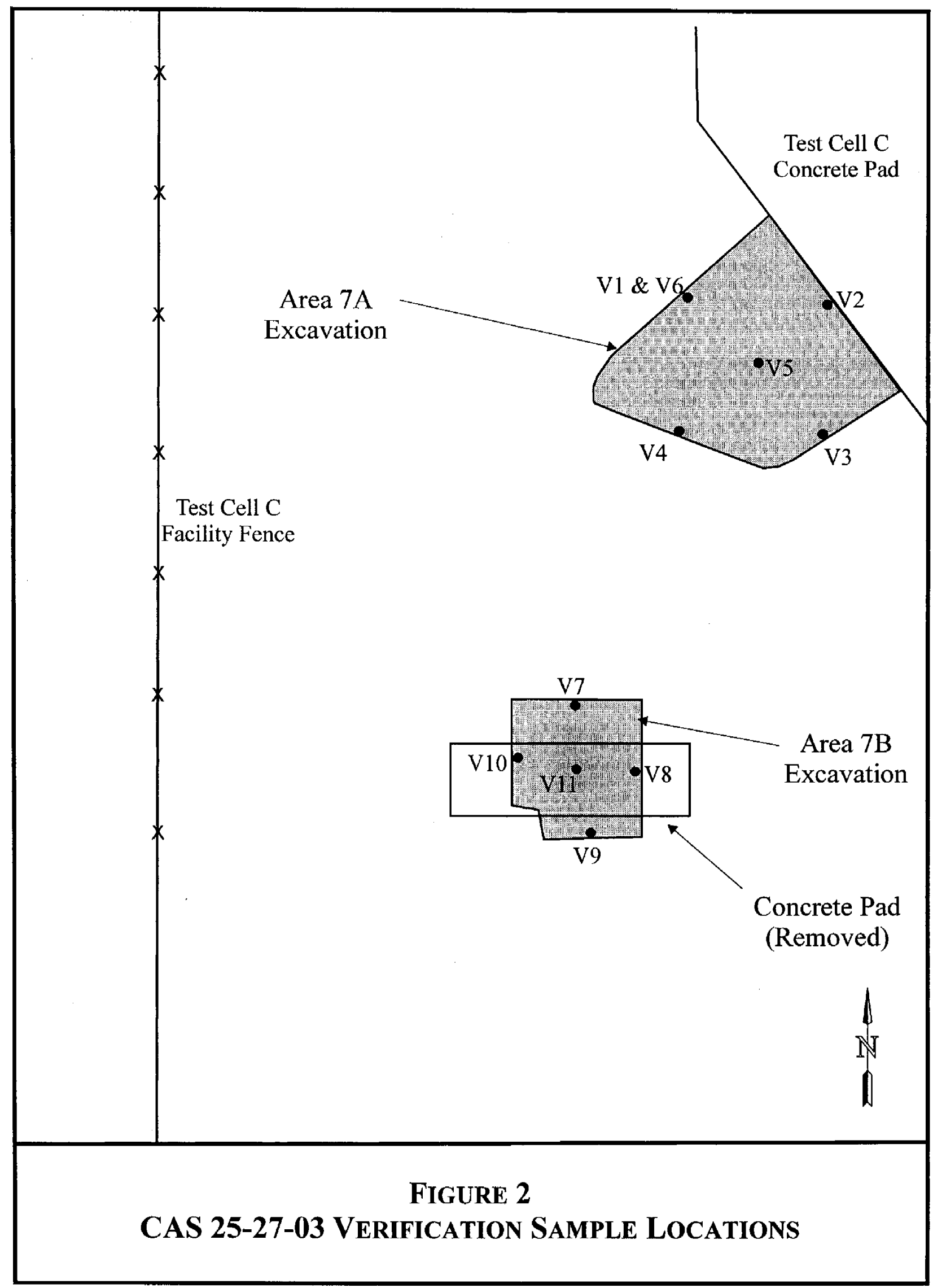




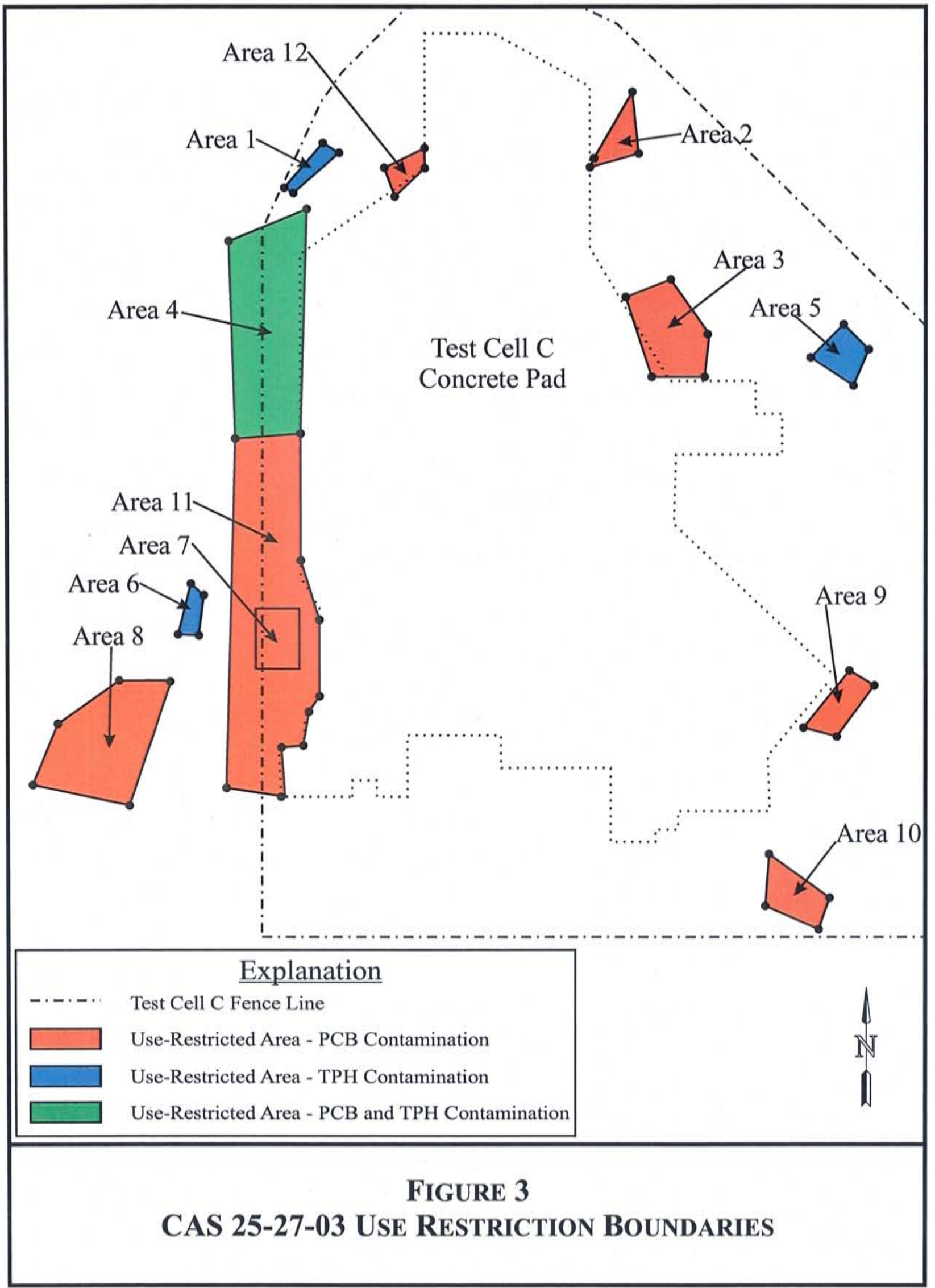




\subsubsection{Transport and Disposal of Excavated Soil}

After receipt of the waste characterization sample results, the waste was transported to the Area 9 U10c Sanitary Landfill.

\subsection{DEVIATIONS FROM THE CAP AS APPROVED}

Closure activities followed the approach specified in the approved CAP (NNSA/NSO, 2005), and no deviations from the CAP occurred during field closure activities.

\subsection{Corrective Action Schedule as Completed}

The closure activities began in May 2006 and were completed in July 2006. Details of the closure field activities schedule are provided in Table 1.

TABle 1. CAU 528 Closure ACtivities SChedule

\begin{tabular}{|l|l|l|}
\hline \multicolumn{1}{|c|}{ ACTIVITY } & \multicolumn{1}{|c|}{ START DATE } & \multicolumn{1}{|c|}{ END DATE } \\
\hline Mobilization and Site Setup & May 11, 2006 & May 15, 2006 \\
\hline Excavation of Impacted Soil & May 16, 2006 & May 18, 2006 \\
\hline Collection of Verification Soil Samples & May 18, 2006 & May 22, 2006 \\
\hline Implementation of URs & May 22, 2006 & May 23, 2006 \\
\hline Transport and Disposal of Excavated Soil & July 20, 2006 & July 20, 2006 \\
\hline
\end{tabular}

\subsection{Site Plan/Survey Plat}

CAS 25-27-03 was closed in place with administrative controls (i.e., UR implemented). A figure showing the locations of the surveyed points delineating the UR areas is included in Appendix D of this report. 
This section describes the waste generated during closure activities and its final disposition. All waste was characterized and managed according to federal and state regulations and U.S. Department of Energy orders. Waste disposition documentation is included in Appendix C of this report.

\subsection{Waste Minimization}

Standard industry waste minimization practices were used throughout the course of closure activities.

\subsection{Container Management}

End-dumps were used to transport the removed concrete pad to the Area 9 U10c Landfill. B25 boxes were used to store and transport the excavated soil. All waste containers were inspected prior to use to verify that they were in good condition (i.e., no leaks, rust, or dents). Containers were closed while stored unless waste was being added or removed. They were also handled in such a manner that the integrity of the containers was not compromised.

\subsection{Waste Characterization}

Waste streams were characterized according to the CAU 528 CAP (NNSA/NSO, 2005). Eight waste characterization samples were collected (four from each B25 box), sealed with a custody seal, cooled to $4^{\circ}$ Celsius, and logged onto a chain of custody. The waste characterization sample results are summarized in Table 2 , and the laboratory result summaries are included in Appendix B of this report. The concentration of PCBs in the waste was less than the NTS Area 9 U10c Sanitary Landfill waste acceptance limit of $50 \mathrm{mg} / \mathrm{kg}$. Therefore, the soil was disposed as sanitary waste at the Area 9 U10c Sanitary Landfill.

\subsection{WASTE STREAMS AND DisPOSAL}

Waste streams generated during closure activities at CAU 528 included non-hazardous sanitary waste. Waste disposition documentation is included in Appendix $\mathrm{C}$ of this report.

\subsubsection{Sanitary Waste}

A total of approximately $14.5 \mathrm{yd}^{3}$ of sanitary waste was generated during closure activities at CAU 528. Approximately $5 \mathrm{yd}^{3}$ of this waste consisted of the concrete pad, and approximately $9.5 \mathrm{yd}^{3}$ of this waste consisted of excavated soil. The soil was determined to be sanitary waste based on waste characterization sample results. Sanitary waste was transported to the NTS Area 9 U10c Sanitary Landfill for disposal. 
Table 2. CaU 528 Waste Characterization Sample Results ${ }^{A}$

\begin{tabular}{|c|c|c|c|c|c|}
\hline $\begin{array}{c}\text { DATE } \\
\text { Counected } \\
\end{array}$ & $\begin{array}{l}\text { SAMPLE } \\
\text { DELIVERY } \\
\text { GROUP }\end{array}$ & $\begin{array}{l}\text { SAMPLE } \\
\text { IDENTIFICATION } \\
\text { NUMBER }\end{array}$ & PCBs (mg/kg) & TCLP Metals (mg/h) & $\begin{array}{l}\text { Gamma } \\
\text { Spectroscopy. } \\
\text { Isotopic } \\
\text { Uranium, and } \\
\text { Isotopic } \\
\text { Plutonium } \\
\end{array}$ \\
\hline \multirow{8}{*}{$05 / 18 / 2006$} & \multirow{8}{*}{$\begin{array}{c}\text { V2685 } \\
\text { (non-radiological) } \\
\text { and } \\
\text { V2686 } \\
\text { (radiological) }\end{array}$} & SWMHZ00213 & Arochlor $-1262=4.6$ & $\begin{array}{c}\text { Arsenic }=0.031 \\
\text { Barium }=0.30\end{array}$ & $<$ PALs \\
\hline & & SWMHZ00214 & Arochlor-1262 $=0.48$ & Barium $=0.22$ & $<$ PALs \\
\hline & & SWMHZ00215 & Arochlor-1262 $=0.26$ & $\begin{array}{c}\text { Arsenic }=0.040 \\
\text { Barium }=0.18\end{array}$ & $<$ PALs \\
\hline & & SWMHZ00216 & Arochlor $-1262=5.8$ & Barium $=0.15$ & $<$ PALs \\
\hline & & SWMHZ00217 & Arochlor $-1262=0.03$ & Barium $=0.19$ & $<$ PALs \\
\hline & & SWMHZ00218 & Arochlor-12.62 $=0.84$ & $\begin{array}{c}\text { Arsenic }=0.027 \\
\text { Barium }=0.19\end{array}$ & $<$ PALs \\
\hline & & SWMHZ00219 & Arochlor-1262 $=0.11$ & $\begin{array}{c}\text { Arsenic }=0.028 \\
\text { Barium }=0.14\end{array}$ & $<$ PALs \\
\hline & & SWMHZ00220 & Arochlor- $1262=0.26$ & Barium $=0.17$ & $<$ PALs \\
\hline
\end{tabular}

Only the detectable sample results are reported here.

$\mathrm{mg} / \mathrm{kg}=$ milligrams per kilogram $\mathrm{mg} / \mathrm{L}=$ milligrams per liter PALs $=$ preliminary action levels PCBs $=$ polychlorinated biphenyls TCLP $=$ Toxicity Characterization Leaching Procedure 
To verify that the clean-up criteria were fulfilled, soil verification samples were collected and analyzed for PCBs. The results showed that the concentration of PCBs remaining in the soil was below the TSCA action level of $25 \mathrm{mg} / \mathrm{kg}$. Figure 2 shows the verification sample locations. The sample results are summarized in Table 3, and the laboratory result summaries are included in Appendix B of this report.

\subsection{Data Quality ASSESSMenT}

Accurate and defensible analytical data were collected to verify that the closure standards were met. The following sections describe the quality assurance (QA)/quality control (QC) procedures, data validation process, and a reconciliation of the primary CSM with actual findings during CAU 528 closure activities. More detail on the QA/QC procedures for CAU 528 can be found in the CAU 528 CAP (NNSA/NSO, 2005).

\subsubsection{Quality Assurance/Quality Control Procedures}

Verification samples were collected with pre-cleaned disposable polyethylene scoops, placed in appropriately labeled sample containers, and secured with custody seals. All samples were labeled with a unique sample number, placed on ice, and transported under a chain of custody. Standard QA/QC samples were collected (i.e., 1 blind duplicate per 20 samples and 1 rinsate blank sample per site). Samples were analyzed by offsite laboratories. Analytical results were validated at the laboratory using stringent QA/QC procedures, including matrix spike/matrix spike duplicates, spiked surrogate recovery analysis, verification of analytical results, and data quality indicator requirements. Detailed information regarding the QA/QC program can be found in the Industrial Sites QAPP (NNSA/NV, 2002).

\subsubsection{Data Validation}

Data validation was performed according to the Industrial Sites QAPP (NNSA/NV, 2002), which is based on the U.S. Environmental Protection Agency (EPA) functional guidelines for data quality (EPA, 1994, 1999). Data were reviewed to ensure that samples were appropriately processed and analyzed, and that the results are valid. All sample data were internally validated by qualified personnel at the Tier I and Tier II levels. No anomalies were discovered in the data that would discredit any of the sample results. While only summary laboratory QC data for verification samples are included in Appendix B of this report, the complete data set, including validation reports for verification samples, is maintained in the project files and is available upon request.

\subsubsection{Conceptual Site Model}

The CSM was developed and presented in the approved CAIP (NNSA/NSO, 2003). The CSM was based on historical documentation and previous analytical results that indicated that PCBs were present in the surface and shallow subsurface. The two suspected sources of contamination are leaking transformers and dust suppression activities conducted throughout the area. No variations to the CSM were identified during closure activities. 
TABLE 3. CAU 528 SOIL VeRIFICATION SAMPLE RESUltS

\begin{tabular}{|c|c|c|c|}
\hline $\begin{array}{l}\text { DATE } \\
\text { COLLECTED }\end{array}$ & $\begin{array}{c}\text { SAMPLE } \\
\text { DELIVERY } \\
\text { GROUP }\end{array}$ & $\begin{array}{l}\text { SAMPLE IDENTIFICATION } \\
\text { NUMBER }\end{array}$ & PCBs $(\mathbf{m g} / \mathrm{kg})$ \\
\hline \multirow{12}{*}{$05 / 22 / 2006$} & \multirow{12}{*}{ V2684 } & 252703-V01 & Arochlor-1262 $=1.5$ \\
\hline & & $252703-V 02$ & Arochlor-1262 $=7.2$ \\
\hline & & $252703-\mathrm{V} 03$ & Arochlor-1262 $=0.4$ \\
\hline & & 252703-V04 & Arochlor-1262 $=1.9$ \\
\hline & & 252703-V05 & Arochlor-1262 $=6.2$ \\
\hline & & 252703-V06 & Arochlor-1262 $=0.05$ \\
\hline & & 252703-V07 & Arochlor $-1262=1.1$ \\
\hline & & 252703-V08 & Arochlor $-1262=0.03$ \\
\hline & & $252703-V 09$ & Arochlor-1262 $=0.01$ \\
\hline & & $252703-\mathrm{V} 10$ & Arochlor-1262 $=0.4$ \\
\hline & & $252703-\mathrm{V} 11$ & Arochlor-1262 $=2.5$ \\
\hline & & 252703-R1 (Rinsate Blank) & ND \\
\hline
\end{tabular}

$\mathrm{mg} / \mathrm{kg}=$ milligrams per kilogram

$\mathrm{ND}=$ not detected above minimum reporting limits

$\mathrm{PCBs}=$ polychlorinated biphenyls

\subsection{USE RESTRICTION}

CAS 25-27-03 consists of 12 areas impacted with TPH and/or PCBs. At Areas 1 through 6 and Areas 8 through 12 , UR warning signs were posted to warn against intrusive activity according to the FFACO Use Restriction Posting Guidance (FFACO, 2003). Area 7 lies within the UR boundary of Area 11. Figure 3 shows the boundaries of the UR areas. The "CAU Land-Use Restriction Information" form and a figure showing the locations of the surveyed points delineating the UR areas are included in Appendix D of this report. Annual site inspections will be required to ensure that the signs are in good repair and that the UR has been maintained. Details on the post-closure requirements for this CAS are included in Section 5.2. 


\subsection{CONCLUSIONS AND RECOMMENDATIONS}

\subsection{CONCLUSIONS}

The following site closure activities were performed at CAU 528:

- Removed a concrete pad and a total of approximately $9.5 \mathrm{yd}^{3}$ of soil impacted with PCBs and disposed as sanitary waste

- Collected verification samples from the remaining soil, and backfilled the excavations

- Implemented URs

\subsection{Post-Closure ReQuirements}

Inspections will be performed on an annual basis at CAS 25-27-03 for the first 5 years and once every 5 years thereafter, for a total of 30 years. The first inspection will take place in calendar year 2007. Inspections will consist of visual observations to verify that the signs are in good repair and that the UR has been maintained. The results of the inspection will be documented on a site inspection checklist and summarized in the annual combined NTS post-closure letter report. The letter report will include a discussion of observations, copies of the site inspection checklists, and any maintenance records. A copy of the annual letter report will be submitted to the NDEP.

If any maintenance and repair requirements are identified during the annual inspection of CAS 25-27-03, funding will be requested and the repairs scheduled. Any repair or maintenance performed at this site will be documented in writing at the time of the repair and included in the annual letter report.

\subsection{RECOMMENDATIONS}

Since closure activities for CAU 528 have been completed following the NDEP-approved CAP (NNSA/NSO, 2005) as documented in this report, NNSA/NSO requests the following:

- A Notice of Completion be provided by NDEP to NNSA/NSO for the closure of CAU 528.

- CAU 528 be transferred from Appendix III to Appendix IV, "Closed Corrective Action Units," of the FFACO (FFACO, 1996). 
Revision: 0

Date: September 2006

THIS PAGE INTENTIONALLY LEFT BLANK 


\subsection{REFERENCES}

Date: September 2006

EPA, see U.S. Environmental Protection Agency.

Federal Facility Agreement and Consent Order. 1996 (as amended). Agreed to by the state of Nevada, the U.S. Department of Energy, and the U.S. Department of Defense.

Federal Facility Agreement and Consent Order. 2003. Use Restriction Posting Guidance.

FFACO, see Federal Facility Agreement and Consent Order.

NNSA/NSO, see U.S. Department of Energy, National Nuclear Security Administration Nevada Site Office.

NNSA/NV, see U.S. Department of Energy, National Nuclear Security Administration Nevada Operations Office.

U.S. Department of Energy, National Nuclear Security Administration Nevada Operations Office. 2002. Nevada Environmental Restoration Project Industrial Sites Quality Assurance Project Plan, Nevada Test Site, Nevada. DOE/NV--372--REV 3. Las Vegas, NV.

U.S. Department of Energy, National Nuclear Security Administration Nevada Site Office. 2003. Corrective Action Investigation Plan for Corrective Action Unit 528: Polychlorinated Biphenyls Contamination, Nevada Test Site, Nevada. DOE/NV--892. Las Vegas, NV.

U.S. Department of Energy, National Nuclear Security Administration Nevada Site Office. 2004. Corrective Action Decision Document for Corrective Action Unit 528: Polychlorinated Biphenyls Contamination, Nevada Test Site, Nevada. DOE/NV--960. Las Vegas, NV.

U.S. Department of Energy, National Nuclear Security Administration Nevada Site Office. 2005. Corrective Action Plan for Corrective Action Unit 528: Polychlorinated Biphenyls Contamination, Nevada Test Site, Nevada. DOE/NV--1059. Las Vegas, NV.

U.S. Environmental Protection Agency. 1994. Guidance for the Data Quality Objectives Process, EPA $Q A / G-4$. Washington, D.C.

U.S. Environmental Protection Agency. 1999. Contract Laboratory Program National Functional Guidelines for Organic Data Review, EPA540/R-99/008. Washington, D.C. 
Closure Report - CAU 528

Section: References

Revision: 0

Date: September 2006

THIS PAGE INTENTIONALLY LEFT BLANK 


\section{APPENDIX A*}

\section{DATA QUALITY OBJECTIVES}

* As presented and published in the approved Corrective Action Investigation Plan for Corrective Action Unit 528: Polychlorinated Biphenyls Contamination, Nevada Test Site, Nevada, 2003, DOE/NV--892. Las Vegas, NV. Only Appendix A.1 of the original report is included here. 
Closure Report - CAU 528

Section: Appendix A

Revision: 0

Date: September 2006

THIS PAGE INTENTIONALLY LEFT BLANK 


\section{A.1 Seven-Step DQO Process for CAU 528 Investigation}

The DQO process described in this appendix is a seven-step strategic planning approach based on the scientific method that is used to plan data collection activities at CAU 528, Polychlorinated Biphenyls Contamination. The DQOs are designed to ensure that the data collected will provide sufficient and reliable information to identify, evaluate, and technically defend the recommended corrective actions (i.e., no further action, closure in place, or clean closure). Existing information about the nature and extent of contamination at the CAS in CAU 528 is insufficient to evaluate and select preferred corrective actions; therefore, a CAI will be conducted.

The CAU 528 investigation will be based on the DQOs presented in this appendix as developed by representatives of the NDEP and the NNSANSO. The seven steps of the DQO process developed for CAU 528 and presented in Sections A.1.2 through A.1.8 were developed based on the CAS-specific information presented in Section A.1.1 and in accordance with EPA Guidance for Quality Assurance Project Plans EPA QA/G-5 (EPA, 2002a). This document identifies and references the associated EPA Quality System Document for DQOs entitled Data Quality Objectives for Hazardous Waste Site investigation EPA $Q A / G-4 H W$ (EPA, 2000), upon which the DQO process presented herein is based.

\section{A.1.1 CAS-Specific Information}

Corrective Action Unit 528 consists of one CAS, CAS 25-27-03, Polychlorinated Biphenyls Contamination, located in an area adjacent to TCC in Area 25 of the NTS as shown in Figure A.1-1. Various nuclear reactor tests were conducted at TCC between 1959 and 1973. Although nuclear rocket engine testing ceased in 1973, various experiments and activities were conducted at TCC until 1977 when the facility was "mothballed." The following presents a summary of the history of the CAS.

Physical Setting and Operational History - Corrective Action Unit 528 was created to address a release of PCBs first identified during the CAI of CAU 262. Analytical results for soil collected during the CAI for CAU 262, CAS 25-04-07, PCBs were detected above the minimum reporting limits, and at some locations above the PALs, in surface soil samples collected from overburden at the TCC Building 3210 sanitary leachfield. This leachfield is located on the west edge of TCC. The 


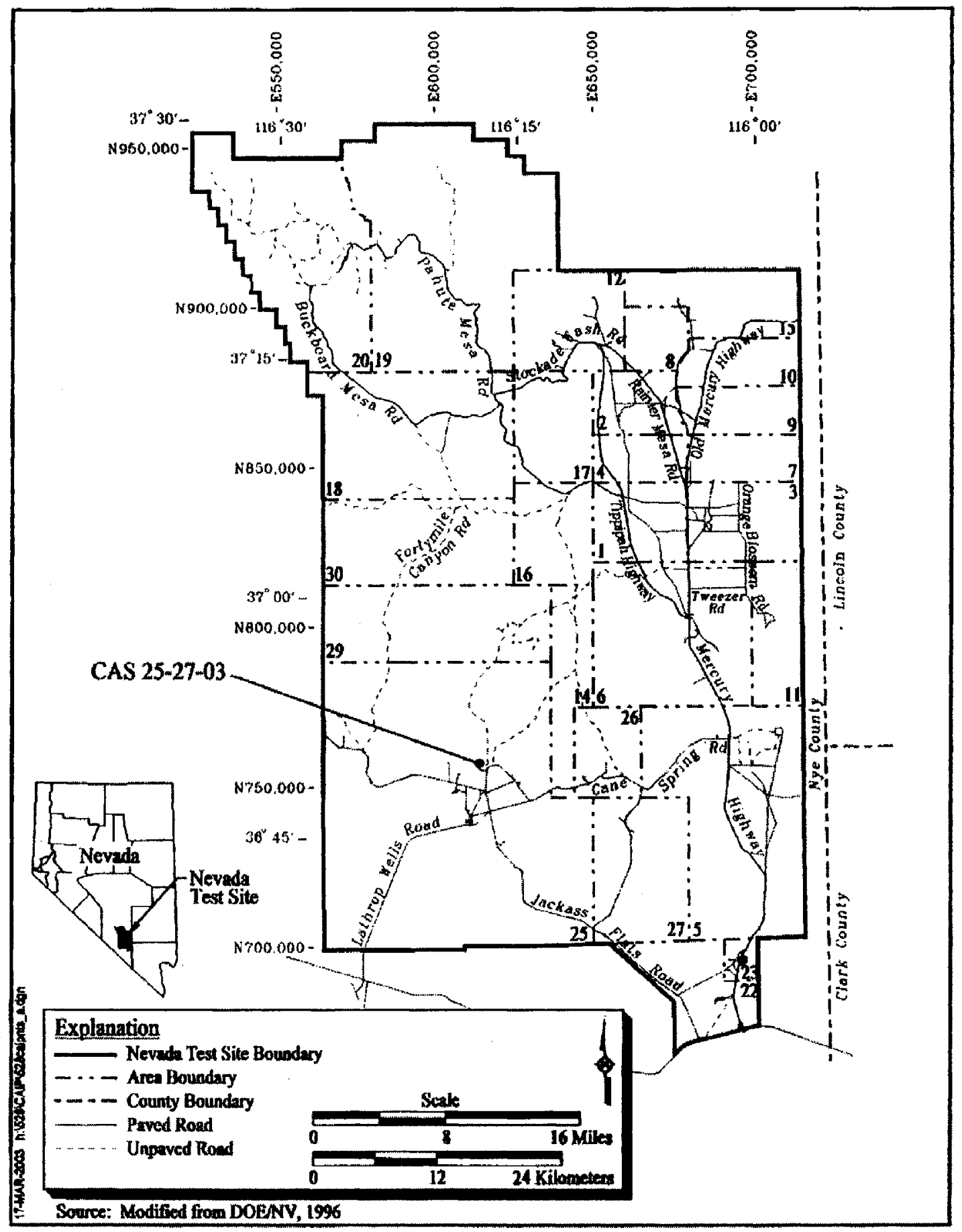

Figure A.1-1

CAU 528, CAS 25-27-03 Location Map 
PCB contamination was not attributed to the septic system (DOE/NV, 2001). CAU 528 and CAS 25-27-03 were created in June 2001 to accommodate the corrective action process for this contamination.

During an August 29, 2002, PA site visit to CAS 25-27-03, Shaw identified two areas of potential environmental concern other than the soils within the CAS: a transformer pad and a small earthern mound located approximately $30 \mathrm{ft}$ north of the transformer pad. Another smaller concrete pad is present near the transformer pad and is surrounded by yellow and orange fencing.

As part of the PA for CAS 25-27-03, Shaw collected surface soil samples in the vicinity of TCC in November and December 2002. Results from this sampling indicated the presence of PCBs throughout the area. Based on this information, CAS 25-27-03 includes Substation \#3, where PCB containing transformers installed in 1961 were located, the earthern berm approximately $30 \mathrm{ft}$ north of the transformer pad, and the surface and shallow subsurface soils contiguous to the TCC concrete pad. The CAS 25-27-03 includes the area adjacent to the TCC west to Topopah Wash and the soil within the fenced area of TCC to the north, east, and south. Figure A.1-2 shows the CAS 25-27-03 boundary based on current understanding.

Sources of Potential Contamination - Two potential sources of the PCB contamination have been identified. First, it is known that oil, potentially containing PCBs, was used in the past for dust suppression during construction and operational activities at the NTS. In addition, the use of oil for controlling wind erosion is known to have occurred in association with the remediation efforts conducted as a result of the Kiwi TNT Excursion and the Phoebus 1A reactor accident at TCC (Tinney, 2001). Potential residual PCB soil contamination within Topopah Wash resulting from the Kiwi TNT Excursion and other testing and subsequent remediation activities are being addressed under CAU 529. However, the areas outside the wash but within the fenced boundary of TCC and an area immediately west of TCC outside of the fenced boundary will be addressed during the CAS 25-27-03 investigation.

The second potential source of PCBs in the surface and shallow subsurface soil are the PCB-containing transformers once located on the concrete pad at Substation \#3. Engineering drawings show that three $100 \mathrm{kVA}$, oil filled, self-cooling transformers were installed at Substation \#3 1961. Because of their insulating and nonflammable properties, PCBs were widely 


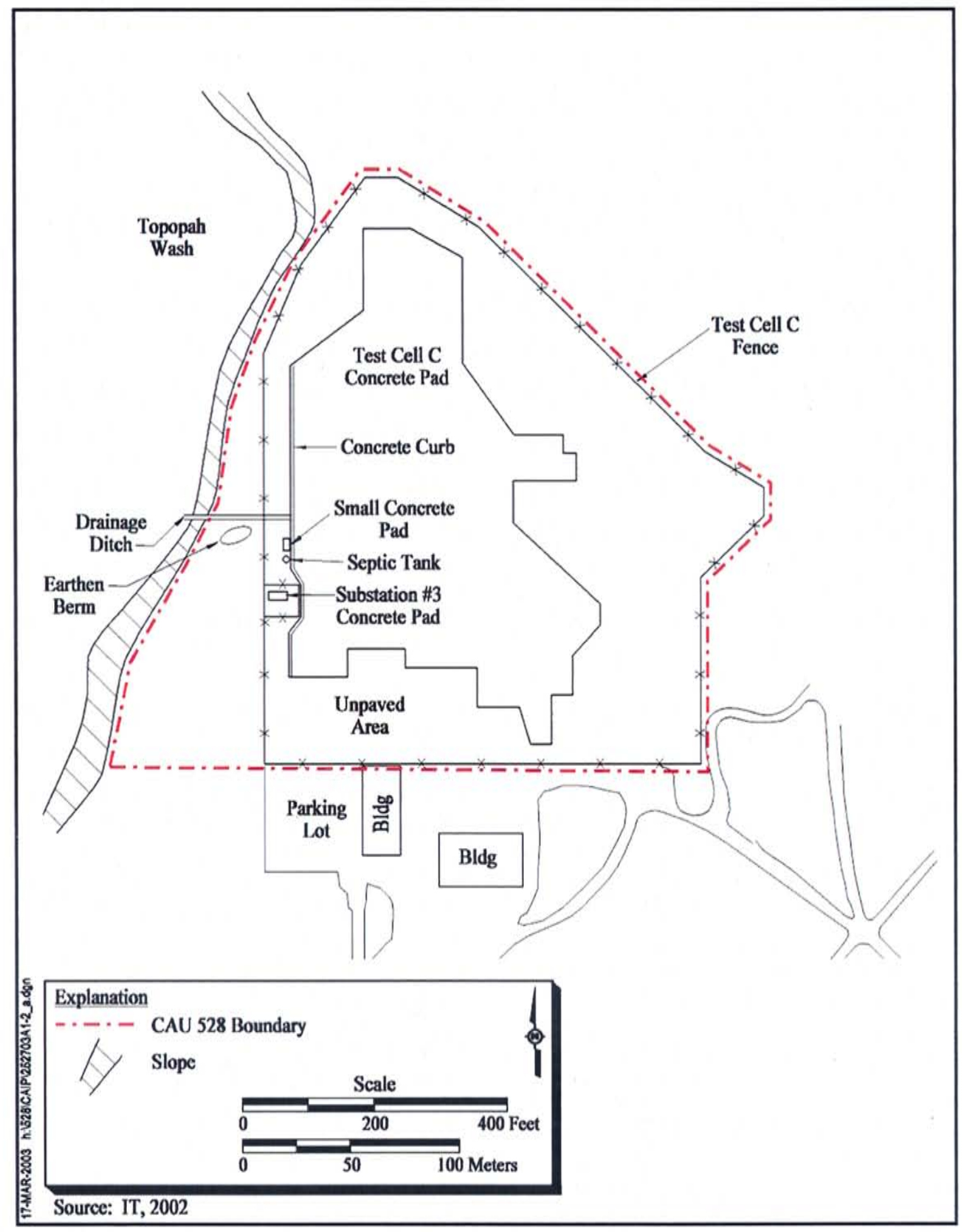

Figure A.1-2

CAU 528, CAS 25-27-03 Boundary 
used as coolants in transformers before 1972. It is possible that a leak from, or a catastrophic failure of, one or more of the transformers may have occurred, although no documentation has been identified to confirm this possibility. The transformers have been removed from the pad, but the date of removal is unknown.

Previous Investigation Results - Analytical results for soil collected at CAS 25-04-07 showed PCBs to be present above the minimum reporting limits in soil samples collected from and near the leachfield overburden. Four samples exceeded the minimum reporting limits for Aroclor-1016, between 0 and $2 \mathrm{ft}$ bgs, but none exceeded the PAL of $740 \mu \mathrm{g} / \mathrm{kg}$. Twenty samples exceeded the minimum reporting limits for Aroclor- 1260 between 0 and $6 \mathrm{ft}$ bgs. Of the 20 total samples, 9 surface and 1 subsurface soil sample contained concentrations of Aroclor-1260 that exceeded the PAL. Of these samples, the highest concentration of PCBs $(57,000 \mu \mathrm{g} / \mathrm{kg}$ Aroclor-1260) was detected in a surface soil sample near the TCC concrete pad (DOE/NV, 2001).

Soil sampling results for other CAU 262 CASs in the TCC area, indicate that PCB contamination is not widespread and is not consistent with sampling results for CAS 25-04-07. However, it must be noted that most of the soil samples for other CASs in the TCC area were collected from the subsurface. Only one soil sample, TAL09A06, taken at CAU 262, CAS 25-04-06, Septic Systems A and $B$, had a $\mathrm{PCB}$ result that exceeded minimum reporting limits, but the concentration was less than the PAL. This sample contained Aroclor-1254 between 6.25 and $6.75 \mathrm{ft}$ bgs (DOE/NV, 2001).

In support of the November 2002 PA for CAU 528, exploratory surface soil samples were collected in the vicinity of the Substation \#3 concrete pad and CAU 262, CAS 25-04-07, on the west side of TCC. The locations are shown in Figure A.1-3. These samples were analyzed for PCBs, TPH-DRO, TPH-GRO, VOCs, SVOCs, pesticides, radionuclides, RCRA metals, and beryllium. The results showed that Aroclor- 1260 was present in the soil at concentrations ranging from $460 \mu \mathrm{g} / \mathrm{kg}$ to $13,000 \mu \mathrm{g} / \mathrm{kg}$. These data show that the PCB contamination extends north, south, and west of the Substation \#3 pad along the west side of the TCC concrete pad. The PCB concentrations in all but two of the samples exceeded the PAL. Total lead also was detected at $140 \mathrm{mg} / \mathrm{kg}$ at one location. Other metals, radionuclides, $\mathrm{m}$ - and p-xylenes, ethylbenzene, and phthalates also were detected at concentrations above the minimum reporting limits in various samples. The radionuclides and metals were present in most of the soil samples, while the VOCs and SVOCs were detected in only three of 


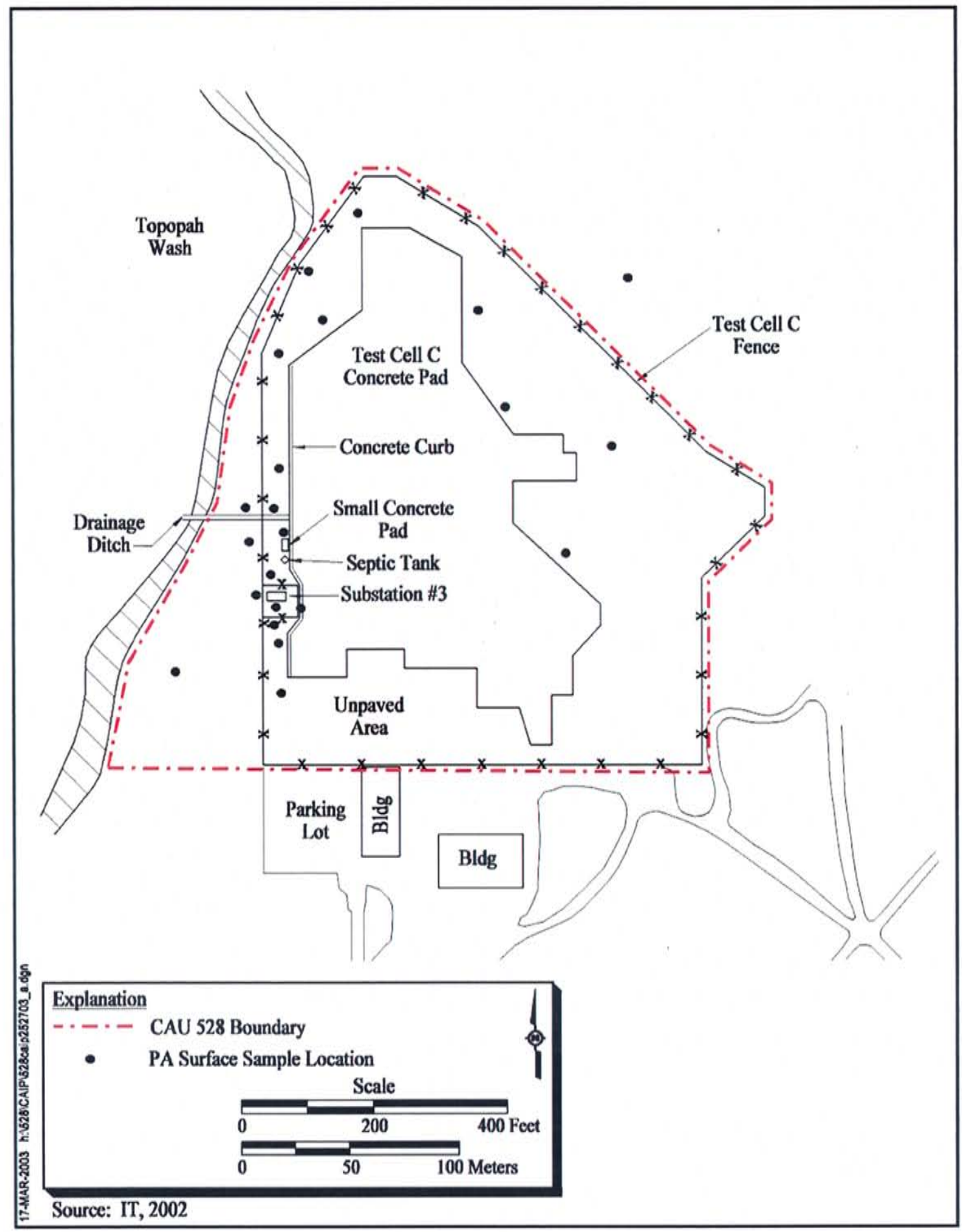

Figure A.1-3

CAU 528, CAS 25-27-03 Preliminary Assessment Surface Soil Sampling Locations 
the samples collected north of Substation \#3 near the drainage ditch leading from the TCC concrete pad to Topopah Wash. The PCB concentrations adjacent to Substation \#3 decrease with distance from the pad; however, concentrations again increase north of the pad adjacent to the previously mentioned drainage ditch leading from TCC to Topopah Wash. This suggests that the PCBs in surface soil are more extensive than originally suspected and probably are not solely associated with the Substation \#3 transformer pad.

Because results from the November 2002 sampling indicated PCB contamination was potentially more widespread than initially indicated, additional surface soil samples were collected in December 2002 and also were analyzed for the full suite of parameters mentioned previously. These samples were collected from the unpaved area along the western, northern, and eastern sides of TCC (Figure A.1-3) and were located in areas that showed evidence of stained soil in historical aerial photographs. The data confirmed that $\mathrm{PCB}$ contamination is more widespread and extends along the edge of the TCC pad north of the original area of concern, and also in a separate area along the northeast side of the TCC pad. Additional information concerning these sampling events is included in the CAIP.

Potential Contamination - Contaminants suspected of being present at CAS 25-27-03 are PCBs metals, and TPH. The VOCs and SVOCs also are suspected of being present because the PA sampling identified minor concentrations of these chemicals in the surface soil. The scope of this investigation is to determine the nature and extent of organic and inorganic contamination associated with the dust suppression activities that took place at TCC and the potential release of oil and PCBs from the Substation \#3 transformers.

Radiological contamination resulting from the Kiwi TNT Excursion, Phoebus 1A accident, and other testing conducted at TCC is outside of the scope of CAU 528. Enough data on radioactivity have already been obtained at CAS 25-27-03 to satisfy health and safety planning needs. Radiological analysis may be required to support waste management decisions and IDW disposal. However, these radiological data are not intended to guide the identification and delineation of contamination within CAS 25-27-03. 


\section{A.1.2 Step 1 - State the Problem}

This initial step of the DQO process identifies the planning team members and decisionmakers, describes the problem that has initiated the CAU $536 \mathrm{CAI}$, and develops the CSM.

\section{A.1.2.1 Planning Team Members}

The DQO planning team consists of representatives from NDEP, NNSA/NSO, Shaw, and Bechtel Nevada (BN). The primary decision-makers include NDEP and NNSA/NSO representatives.

Table A.1-1 lists representatives from each organization in attendance at the February 4, 2002, DQO planning meeting.

Table A.1-1

DQO Meeting Participants

\begin{tabular}{|c|c|}
\hline Participant & Affiliation \\
\hline Sabine Curtis & NNSA/NSO \\
\hline Terrylynn Foley & Shaw \\
\hline John M. Fowler & Shaw \\
\hline Orin L. Haworth & BN \\
\hline Joe Hutchinson & SAIC \\
\hline Lynn Kidman & Shaw \\
\hline Barbara Quinn & SAIC \\
\hline Robert Sobocinski & Shaw \\
\hline Amber Steed & SAIC \\
\hline Allison Urbon & BN \\
\hline Alfred Wickline & SAIC \\
\hline Jeanne Wightman & Shaw \\
\hline John Wong & NDEP \\
\hline
\end{tabular}

BN - Bechtel Nevada

Shaw - Shaw Environmental, Inc.

NDEP - Nevada Division of Environmental Protection

NNSANSO - U.S. Department of Energy, National Nuclear Security Administration

Nevada Site Office

SAIC - Science Applications International Corporation 


\section{A.1.2.2 Describe the Problem}

Corrective Action Unit 528 is being investigated because CAS 25-27-03 is located at the inactive and abandoned TCC that may not comply with the requirements of future land use.

The PCBs and related contaminants may be present at CAS 25-27-03 at concentrations that could potentially pose a threat to human health and the environment. The problem statement for CAU 528 is: "Existing information on the nature of other suspected contaminants and extent of PCBs and potential contamination is insufficient to evaluate and recommend corrective action alternatives for CAS 25-27-03,"

\section{A.1.2.3 Develop A Conceptual Site Model}

A CSM describes the most probable scenario for current conditions at a CAS and defines the assumptions that are the basis for identifying appropriate sampling strategy and data collection methods. It is the basis for assessing how contaminants could reach receptors both in the present and future by addressing contaminant nature and extent, transport mechanisms and pathways, potential receptors, and potential exposures to those receptors. Accurate CSMs are important because they serve as the starting point for all subsequent inputs and decisions throughout the DQO process.

Different CSMs for a single CAS or CAU are not dependent on the types of contaminants suspected, the geographic location, or being part of an engineered system, but rather the release mechanism and potential migration pathways that may influence the sampling strategies. Because the release mechanism and migration pathways are the same for the two potential sources, a single CSM has been developed for CAU 528, CAS 25-27-03.

An important element of a CSM is the expected fate and transport of contaminants, which infer how contaminants move through site media and where they can be expected in the environment. The expected fate and transport is based on distinguishing physical and chemical characteristics of the suspected contaminants and media. The PCBs with a high degree of chlorination (e.g., Aroclor-1248, -1254 , and -1260) are resistant to biodegradation and have been shown to degrade very slowly in the environment. Contaminant characteristics include biodegradation potential, solubility, density, and affinity for nonmobile particles (adsorption). Media characteristics include permeability, porosity, hydraulic conductivity, total organic carbon content, and adsorption coefficients. In general, 
contaminants with low solubility and high density can be expected to be found relatively close to release points. Contaminants with high solubility and low density are more susceptible to factors that can move them through various media; therefore, can be expected to be found further from release points.

A review of historical documentation and analytical results from CAU 262 and subsequent PA sampling indicate that PCBs are present in the surface and shallow subsurface at concentrations exceeding the PAL. There is no documented evidence of where this contamination originated. A CSM has been developed for CAS 25-27-03 using the historical background information, knowledge from studies at similar sites, and analytical data from the previous sampling efforts. The CSM is based on the two suspected sources of PCB contamination discussed in Section A.1.1: the failure or leaking of transformers at Substation \#3, and dust suppression and wind erosion control conducted throughout the TCC area. The two suspected sources are termed transformer release and dust suppression, respectively. The CSM is shown in Figure A.1-4 and discussed in the following paragraphs.

If the Substation \#3 transformers leaked or failed, contamination would have been released onto the concrete pad and then flowed onto the adjacent surface soil. Because of the condition of the pad (i.e., good integrity) PCBs and/or petroleum contamination associated with the transformers is not expected beneath the pad. This scenario predicts that if a release occurred as a result of the failure of the transformers, the location most likely to be contaminated would be the soil directly adjacent to the sides of the concrete pad. Contaminants would be expected to migrate away from the release point, primarily downward, and to a lesser degree horizontally. Analytical results from preliminary sampling conducted around and in the area of Substation \#3 concrete pad in November 2002 confirmed the presence of PCBs in the surface soil at concentrations that exceed the PALs. However, the concentration gradient either horizontally or vertically is not known. Based on the physical and chemical properties of the PCBs, it is expected that contamination would be somewhat localized at the point of release and decrease with distance from the transformer pad.

Used oil potentially containing PCBs and metals may have been used to suppress dust and control wind erosion during the construction and operation of TCC. Petroleum products containing PCBs may have been sprayed onto the ground surface during discrete events. Reworking of the soil during 


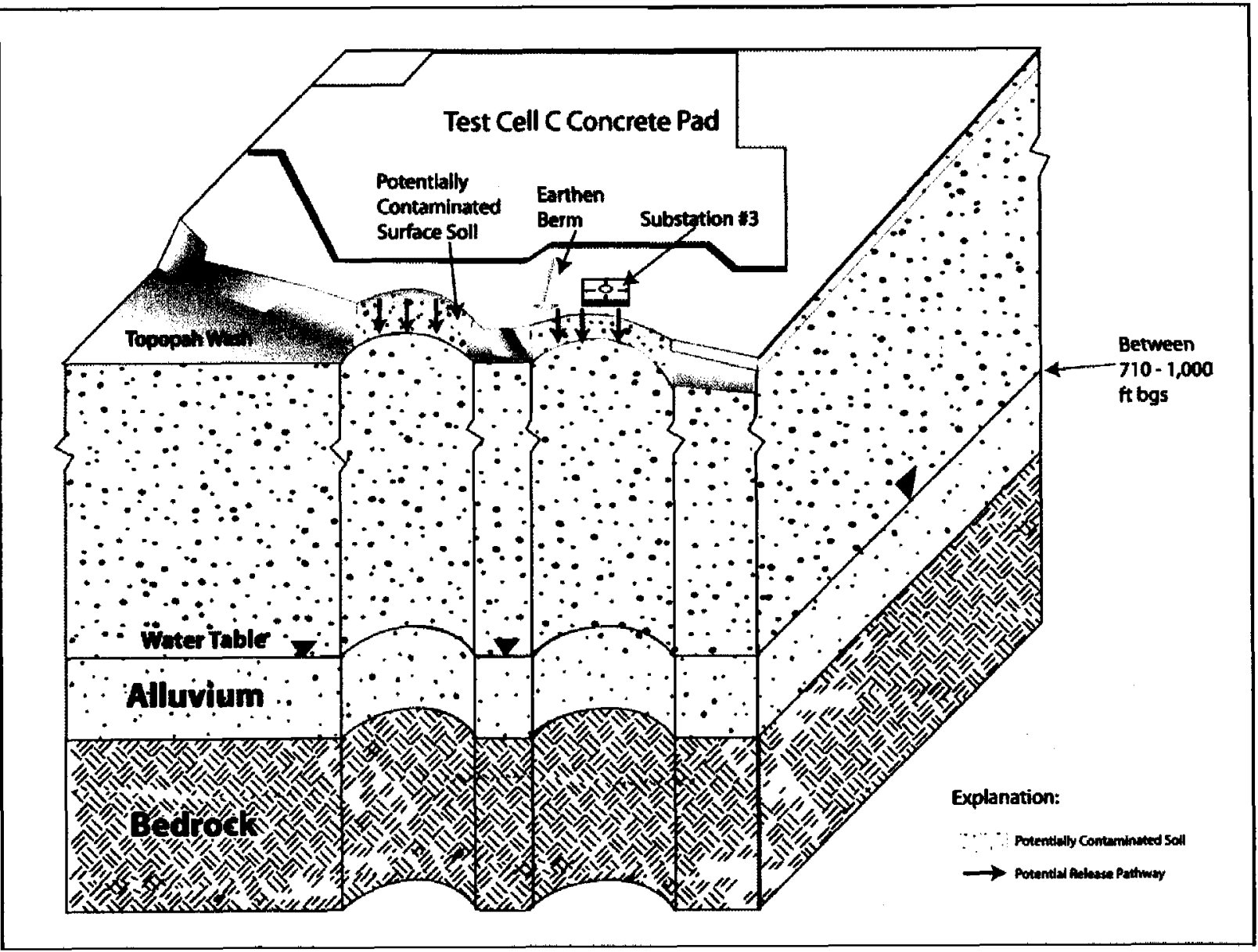

Figure A.1-4

\section{CAU 528 Conceptual Site Model}

TCC construction and operations could have physically transported contamination into shallow subsurface soil at some locations. Because the extent and frequency of the dust suppression activities is unknown, the potential contamination may appear to be randomly distributed throughout the site with no obvious source. The analytical results from the PA sampling support the theory that there are sources of PCB contamination other than the transformer release. Therefore, this scenario warrants further consideration. Shallow subsurface PCB contamination may have resulted from downward migration of the contaminated oil or, as discussed above, reworking of surface soils subsequent to the initial release. The CSM predicts that the concentration of contaminants would be highest in the surface soil without an obvious lateral concentration gradient to suggest a release point. However, in both scenarios, shallow subsurface contamination could be caused by the reworking of the surface soil subsequent to the release(s) of contamination. 
Based upon the CSM, contamination found at CAS 25-27-03 would result from the failure of the transformers formerly located on a concrete pad at Substation \#3 and/or direct application of oil containing PCBs on the surface soil. Insufficient records are available for the suspected source activities to specifically identify chemicals present in the soil. Therefore, COPC information is based upon previous sampling and analysis, limited historical documentation, interviews with current/former site employees, and site visits.

If additional areas or elements are identified during the CAI that go beyond the area or situation identified for investigation in the CSM, the situation will be reviewed and recommendations will be made to revise Step 4 (Define the Study Boundaries) of the DQO process and/or revise the sampling approach. The DQOs will be reviewed and any significant deviation from the planned approach will be presented to the decision makers for approval.

The following discussion of the CSM parameters provide additional details to supplement this model.

Exposure Scenario - The potential for exposure to contamination at the CAU 528 CAS is limited to industrial and construction workers as well as military personnel conducting training (DOE/NV, 1998). These human receptors may be exposed to COPCs through ingestion, inhalation, dermal contact (absorption) from soil and/or debris (e.g., equipment, concrete) due to inadvertent disturbance of these materials. The future land-use scenario limits uses of the CAU to various nonresidential uses (i.e., industrial uses) and include, defense and nondefense research, development, and testing activities (Table A.1-2).

Table A.1-2

Future Land-Use Scenarios for CAS 25-27-03 Within CAU 528

\begin{tabular}{|c|l||}
\hline Land Use Zone & \multicolumn{1}{c|}{ Zone Description } \\
\hline \hline $\begin{array}{c}\text { Research, Test, and } \\
\text { Experiment Zone }\end{array}$ & $\begin{array}{l}\text { This area is designated for small-scale research and development } \\
\text { projects and demonstrations; pilot projects; outdoor tests; and } \\
\text { experiments for the development, quality assurance, or reliability of } \\
\text { material and equipment under controlled conditions. This zone includes } \\
\text { compatible defense and nondefense research, development and testing } \\
\text { projects and activities (DOE/NV, 1998). }\end{array}$ \\
\hline
\end{tabular}


CAU 528 CAIP

Appendix A.1

Revision: 0

Date: $05 / 20 / 2003$

Page A-14 of $A-42$

Affected Media - For the dust suppression scenarios, the potentially affected medium is the surface and shallow subsurface soil throughout the CAS. Because of the unknown procedures employed for dust suppression around TCC, the area potentially affected is unknown. For a release from the transformers, the potentially affected media are the concrete pad, surface and subsurface soil near the Substation \#3 pad.

Contamination/Release - Releases to the environment from the suppression of dust during operation or construction activities associated with TCC will be present in the surface or shallow subsurface soil. Under this scenario, the surface soil throughout the CAS would have been the most likely point of release to the environment; therefore, should contain the highest concentrations of the released constituents. Potential contaminant concentrations in the soil beyond the TCC concrete pad could be random with no obvious pattern and may also be found in shallow subsurface soils, if the PCBs and/or petroleum hydrocarbons migrated vertically or if physical mixing occurred during construction or operation activities at TCC. Because dust suppression would have been performed by applying discrete batches of waste oils, and the PCB concentration of individual batches would have varied, it is possible that the PCB contamination may be present in areas where individual batches of waste oil containing PCBs were applied rather than in "hot spots." Review of documentation including Los Alamos Scientific Laboratory (LASL) (1967) indicates that the pad was constructed in sections between 1961 and 1967.

For a transformer release, contaminants would be expected to be present on the substation pad and in the surface and shallow subsurface adjacent to the pad. The highest concentration of PCBs and petroleum hydrocarbons would be expected in the surface soil adjacent to the sides of the concrete pad. Again, physical mixing due to surface activities or vertical migration could distribute the contamination in shallow subsurface soil.

Transport Mechanisms - The degree of contaminant migration at this site is unknown, but it is assumed to be minimal based on the affinity of the PCBs and petroleum hydrocarbons for soil particles, and the low precipitation and high evapotranspiration rates typical of the NTS environment. Runoff could cause lateral migration of contaminants over the ground surface for both release scenarios. Contaminants may also have been transported by infiltration and percolation of precipitation through soil, which would serve as the primary driving force for downward migration. 
Mixing of the surface soil as a result of grading or construction activities would also move the PCBs into deeper intervals. The migration of organic constituents (e.g., petroleum hydrocarbons, PCBs) can be controlled to some extent by their affinity for organic material present in soil. However, this mechanism is considered insignificant because of the lack of organic carbon in the desert soil around TCC. Migration of certain inorganic constituents (e.g., metals in waste oil) is controlled by geochemical processes, such as adsorption, ion exchange, and precipitation of solids from solution.

Because of the low volatility of the PCBs and other suspected contaminants, an airborne release subsequent to the initial contaminant release is not considered a significant release pathway. The main process of migration through the air would be through windblown dust. If PCBs, SVOCs, metals, or petroleum hydrocarbons adsorbed to the fine soil particles, a small amount of migration could be expected via the airborne pathway. This process could allow for the deposition of contaminants beyond the site boundaries. For all transport mechanisms, it would be expected that contaminant levels decrease with distance from the point of release.

Preferential Pathways - Preferential pathways for contaminant migration at CAS 25-27-03 are expected not to be present or have only had a minor impact on contaminant migration. The presence of relatively impermeable layers (e.g., caliche layers, concrete pads) modify transport pathways both on the ground surface and in the shallow subsurface. Small gullies, if present, could channelize runoff and increase lateral transport prior to infiltration. Rain may wash PCBs off the concrete pad onto the surrounding soil. Contamination could travel laterally to a small degree under both scenarios. Although the preferential pathways for contaminant migration will be considered in the development of sampling schemes and sampling contingencies discussed in the CAIP, primary consideration will be given to the release and transport mechanisms.

Lateral and Vertical Extent of Contamination - If contamination is present, it is expected to be confined to the surface and shallow subsurface at the site. Concentrations of contamination are expected to decrease with distance (both horizontally and vertically) from the release points. Surface migration may occur as a result of storm events when precipitation rates exceed infiltration (stormwater runoff). However, these events are infrequent. Surface migration is a biasing factor considered in the selection of sampling points. As stated previously, downward contaminant 
transport is expected to be limited but is unknown because the quantities of hazardous material released is unknown.

Migration of contamination for the two release scenarios would be expected to be primarily downward, with horizontal migration to a much lesser extent. The lateral extent of contamination, due to dust suppression activities, would expected to extend over a larger area as a result of the deposition mechanism rather than as a result of lateral migration. Minor amounts of lateral migration may occur due to periodic stormwater runoff. The mixing of the soil at and near the surface also would influence the lateral and vertical extent of contamination.

Groundwater contamination is not considered a likely scenario at CAU 528, due to minimal precipitation, high evapotranspiration, strong attenuation of suspected contaminants in the soil, and significant depths to groundwater. For example, depths to groundwater in Area 25 wells have been recorded between $740 \mathrm{ft}$ bgs at Well J-13 to 1,040.25 ft bgs at well J-11 (USGS, 2002).

\section{A.1.3 Step 2-Identify the Decision}

Step 2 of the DQO process identifies the decisions statements and defines alternative actions. Also presented is this section is the decision logic for the entire process.

\section{A.1.3.1 Develop Decision Statements}

The primary problem statement is: Insufficient information is available concerning the nature of suspected contamination other than PCBs and extent of contamination released at CAS 25-27-03 to determine if there is an unacceptable risk to human health and the environment. Because existing information at this CAS is insufficient to resolve the problem statement, the following two decision statements have been established as criteria for determining the adequacy of the data collected during the CAI.

The Decision I statement is: "Is a contaminant other than PCBs present within CAS 25-27-03 at a concentration that could pose and unacceptable risk to human health and the environment?" Any contaminant detected at a concentration exceeding the corresponding PAL, as defined in Section A.1.4.2, will be considered a COC. The presence of a contaminant within this CAS is 
defined as the analytical detection of a COC. Samples used to resolve Decision I are identified as Phase I samples.

The Decision II statement is: "If a COC is present, is sufficient information available to evaluate appropriate corrective action alternatives?" Sufficient information is defined as the data needs identified in this DQO process to include the lateral and vertical extent of the PCBs and all COCs within the CAS. Samples used to resolve Decision II are identified as Phase II samples.

\section{A.1.3.2 Alternative Actions to the Decisions}

For each decision identified in the previous section there is an alternate decision.

The alternate for Decision I is: If a COC other than PCBs is not present, further assessment of the CAS other than the delineation of the PCBs is not required. If a COC in addition to PCBs is present, resolve Decision II.

The alternate for Decision II is: If the extent of the PCBs and any other COC is defined in both the lateral and vertical direction, further assessment of the CAS is not required. If the extent of a COC is not defined, reevaluate site conditions and collect additional samples.

\section{A.1.4 Step 3 - Identify the Inputs to the Decisions}

This step identifies the information needed, determines sources for information, determines the basis for establishing action levels, and identifies sampling and analysis methods that can meet the data requirements. To determine if a $\mathrm{COC}$ is present other than $\mathrm{PCBs,} \mathrm{each} \mathrm{sample} \mathrm{result} \mathrm{is} \mathrm{compared} \mathrm{to} \mathrm{a}$ PAL (Section A.1.4.2). If any sample result exceeds the PAL, then the CAS is advanced to Decision II (define the lateral and vertical extent) for that parameter. This approach does not use a statistical mean/average for comparison to the PALs, but rather a point-by-point comparison to the established screening criteria to identify COCs.

\section{A.1.4.1 Information Needs and Information Sources}

In order to determine if COC other than PCBs is present at CAS 25-27-03, sample data must be collected and analyzed following these two criteria: (1) samples must be collected in areas most 
likely to be contaminated, and (2) the analytical suite selected must be sufficient to detect any contamination present in the samples. Biasing factors to support criteria \#1 include:

- Previous sample results

- Documented process knowledge on source and location of release

- Field observations

- Potential runoff area from the TCC concrete pad

- Field screening data

- Experience and data from investigations of similar sites

- Professional judgement

- Radiological field screening results

In order to determine the extent of a COC for Decision II, Phase II samples will be collected from locations to bound the lateral and vertical extent. For Phase II sampling, analytical suites will only include those parameters that exceed PALs (i.e., COCs) in prior samples. The data required to satisfy the information needs for Decision II for each COC is a sample concentration that is below the corresponding PAL. Step-out locations will be selected based on the CSM, biasing factors, FSRs, and Phase I analytical results. When analytical results or other biasing factors suggest that the COC concentrations, at the step-out location(s), may still exceed the PAL, then an additional step-out distance may be used to define the lateral extent of contamination. If a location where the PAL is exceeded is surrounded by clean locations, then lateral step-outs may not be necessary. In that case, sampling may consist only of sampling from deeper intervals at or near the original location to determine the vertical extent of contamination. Vertical extent samples will be collected from depth intervals that will meet DQO objectives and in a manner that will conserve resources during possible remediation. Biasing factors to support these information needs may include the factors previously listed and Phase I analytical results. Sampling locations may be moved due to access problems, underground utilities, or safety issues; however, the modified locations must meet the decision requirements and criteria necessary to fulfill the information needs.

Table A.1-3 lists the information needs, the source of information for each need, and the proposed methods to collect the data needed to resolve Decisions I and II. The last column addresses the QA/QC data type and associated metric. The data type is determined by the intended use of the resulting data in decision making. 
Table A.1-3

Information Needs to Resolve Decisions I and II

(Page 1 of 3 )

\begin{tabular}{|c|c|c|c|c|}
\hline $\begin{array}{l}\text { Information } \\
\text { Need }\end{array}$ & $\begin{array}{l}\text { Information } \\
\text { Source }\end{array}$ & Collection Method & $\begin{array}{l}\text { Biasing } \\
\text { Factors to } \\
\text { Consider }\end{array}$ & Data Type/Metric \\
\hline & $\begin{array}{l}\text { Decision } \\
\text { ria l: Samples n }\end{array}$ & $\begin{array}{l}\text { Phase I): Determine if a C } \\
\text { st be collected in areas mo }\end{array}$ & $\begin{array}{l}\text { is present. } \\
\text { likely to contai }\end{array}$ & SOC. \\
\hline \multirow{5}{*}{$\begin{array}{l}\text { Source and } \\
\text { location of } \\
\text { release points }\end{array}$} & $\begin{array}{l}\text { Process knowledge, } \\
\text { historical } \\
\text { documentation, and } \\
\text { previous } \\
\text { investigations of } \\
\text { similar sites }\end{array}$ & $\begin{array}{l}\text { Information documented in } \\
\text { CSM and public reports - no } \\
\text { additional data needed }\end{array}$ & None & $\begin{array}{c}\text { Qualitative - CSM } \\
\text { has not been shown } \\
\text { to be inaccurate }\end{array}$ \\
\hline & Field observations & $\begin{array}{l}\text { Conduct site visits and } \\
\text { document field observations }\end{array}$ & $\begin{array}{l}\text { Visible evidence } \\
\text { of contamination, } \\
\text { topographic } \\
\text { lows, gullies }\end{array}$ & $\begin{array}{c}\text { Qualitative - CSM } \\
\text { has not been shown } \\
\text { to be inaccurate }\end{array}$ \\
\hline & Aerial photographs & $\begin{array}{c}\text { Review and interpret aerial } \\
\text { photographs }\end{array}$ & $\begin{array}{c}\text { Disturbed areas, } \\
\text { visible evidence } \\
\text { of contamination, } \\
\text { location of } \\
\text { possible sources }\end{array}$ & $\begin{array}{c}\text { Semiquantitative - } \\
\text { Sampling based on } \\
\text { biasing criteria } \\
\text { stipulated in DQO } \\
\text { Step } 3\end{array}$ \\
\hline & Field screening & Review and interpret FSRs & $\begin{array}{c}\text { Bias sample } \\
\text { locations/ } \\
\text { intervals based } \\
\text { on elevated } \\
\text { FSRs }\end{array}$ & $\begin{array}{c}\text { Semiquantitative - } \\
\text { Sampling based on } \\
\text { biasing criteria } \\
\text { stipulated in DQO } \\
\text { Step } 3\end{array}$ \\
\hline & $\begin{array}{l}\text { Existing analytical } \\
\text { data }\end{array}$ & $\begin{array}{l}\text { Review and interpret sampling } \\
\text { results }\end{array}$ & $\begin{array}{l}\text { Bias sample } \\
\text { locations based } \\
\text { on previous } \\
\text { results }\end{array}$ & $\begin{array}{c}\text { Semiquantitative - } \\
\text { Sampling based on } \\
\text { biasing criteria } \\
\text { stipulated in DQO } \\
\text { Step } 3\end{array}$ \\
\hline \multirow[t]{2}{*}{$\begin{array}{c}\text { Nature of } \\
\text { contamination }\end{array}$} & Biased samples & $\begin{array}{c}\text { Collect samples from } \\
\text { locations/depths based on } \\
\text { biasing factors }\end{array}$ & $\begin{array}{l}\text { Send samples } \\
\text { for quick- } \\
\text { turnaround } \\
\text { analysis to } \\
\text { laboratory }\end{array}$ & $\begin{array}{l}\text { Quantitative - } \\
\text { Sampling based on } \\
\text { quick-turnaround } \\
\text { analytical results }\end{array}$ \\
\hline & Biased samples & $\begin{array}{c}\text { Collect samples from } \\
\text { additional locations near CAS } \\
\text { features }\end{array}$ & $\begin{array}{l}\text { Worst-case } \\
\text { locations such as } \\
\text { edge of pad }\end{array}$ & $\begin{array}{c}\text { Quantitative - } \\
\text { Sampling based on } \\
\text { CAS features }\end{array}$ \\
\hline
\end{tabular}


Table A.1-3

Information Needs to Resolve Decisions I and II (Page 2 of 3 )

\begin{tabular}{|c|c|c|c|c|}
\hline $\begin{array}{l}\text { Information } \\
\text { Need }\end{array}$ & $\begin{array}{l}\text { Information } \\
\text { Source }\end{array}$ & Collection Method & $\begin{array}{l}\text { Biasing } \\
\text { Factors to } \\
\text { Consider }\end{array}$ & Data Type/Metric \\
\hline \multicolumn{5}{|c|}{$\begin{array}{l}\text { Decision I (Phase I): Determine if a COC is present. } \\
\text { : Analyses must be sufficient to detect any COCs in }\end{array}$} \\
\hline $\begin{array}{l}\text { Identification } \\
\text { of all potential } \\
\text { contaminants }\end{array}$ & $\begin{array}{l}\text { Process knowledge } \\
\text { and previous } \\
\text { investigations of } \\
\text { similar sites; use } \\
\text { analytical suite in } \\
\text { Table A.1-4. }\end{array}$ & $\begin{array}{l}\text { Information documented in } \\
\text { CSM and public reports - no } \\
\text { additional data needed; } \\
\text { comprehensive analytical suite } \\
\text { developed to account for } \\
\text { uncertainty. }\end{array}$ & None & $\begin{array}{l}\text { Qualitative - CSM } \\
\text { has not been shown } \\
\text { to be inaccurate }\end{array}$ \\
\hline $\begin{array}{l}\text { Analytical } \\
\text { results }\end{array}$ & $\begin{array}{l}\text { Data packages from } \\
\text { biased samples }\end{array}$ & $\begin{array}{c}\text { Appropriate sampling } \\
\text { techniques and approved } \\
\text { analytical methods will be } \\
\text { used; MRLs are sufficient to } \\
\text { provide quantitative results for } \\
\text { comparison to PALs }\end{array}$ & None & $\begin{array}{l}\text { Quantitative - } \\
\text { Validated analytical } \\
\text { results will be } \\
\text { compared to PALs }\end{array}$ \\
\hline \multicolumn{5}{|c|}{$\begin{array}{l}\text { Decision II (Phase II): Determine the extent of a COC. } \\
\text { Criteria: Sample collection and analysis methods must be sufficient to bound extent of COC. }\end{array}$} \\
\hline $\begin{array}{l}\text { Identification } \\
\text { of applicable } \\
\text { COCs }\end{array}$ & $\begin{array}{l}\text { Data packages of } \\
\text { Phase I samples }\end{array}$ & $\begin{array}{c}\text { Review analytical results and } \\
\text { compare to PALs to select } \\
\text { COCs }\end{array}$ & None & $\begin{array}{c}\text { Quantitative - Only } \\
\text { COCs identified will } \\
\text { be analyzed in future } \\
\text { sampling events }\end{array}$ \\
\hline \multirow{4}{*}{$\begin{array}{l}\text { Extent of } \\
\text { Contamination }\end{array}$} & Field observations & Document field observations & $\begin{array}{l}\text { Visible evidence } \\
\text { of contamination }\end{array}$ & $\begin{array}{l}\text { Qualitative - CSM has } \\
\text { not been shown to be } \\
\text { inaccurate }\end{array}$ \\
\hline & Field screening & $\begin{array}{l}\text { Conduct field screening using } \\
\text { appropriate methods }\end{array}$ & $\begin{array}{c}\text { Bias sample } \\
\text { locations/ } \\
\text { intervals based } \\
\text { on FSRs }\end{array}$ & $\begin{array}{l}\text { Semiquantitative - } \\
\text { FSRs will be } \\
\text { compared to field } \\
\text { screening levels }\end{array}$ \\
\hline & Step-out samples & $\begin{array}{l}\text { Generate locations based on } \\
\text { previous sampling results and } \\
\text { biasing factors }\end{array}$ & $\begin{array}{l}\text { Locations } \\
\text { selected based } \\
\text { on the initial } \\
\text { sampling results } \\
\text { for both } \\
\text { horizontal and } \\
\text { vertical } \\
\text { sampling. }\end{array}$ & $\begin{array}{l}\text { Semiquantitative - } \\
\text { Sampling based on } \\
\text { previous results and } \\
\text { biasing factors }\end{array}$ \\
\hline & $\begin{array}{l}\text { Data packages of } \\
\text { analytical results }\end{array}$ & $\begin{array}{l}\text { Appropriate sampling } \\
\text { techniques and approved } \\
\text { analytical methods will be used } \\
\text { to bound COCs; MRLs are } \\
\text { sufficient to provide } \\
\text { quantitative results for } \\
\text { comparison to PALs }\end{array}$ & None & $\begin{array}{l}\text { Quantitative - } \\
\text { Validated analytical } \\
\text { results will be } \\
\text { compared to PALS to } \\
\text { determine COC } \\
\text { extent }\end{array}$ \\
\hline
\end{tabular}


Table A.1-3

Information Needs to Resolve Decisions I and II (Page 3 of 3 )

\begin{tabular}{|c|c|c|c|c|}
\hline $\begin{array}{c}\text { Information } \\
\text { Need }\end{array}$ & $\begin{array}{l}\text { Information } \\
\text { Source }\end{array}$ & Collection Method & $\begin{array}{l}\text { Biasing } \\
\text { Factors to } \\
\text { Consider }\end{array}$ & Data Type/Metric \\
\hline \multicolumn{5}{|c|}{$\begin{array}{l}\text { Decision: Determine if sufficient information exists to characterize waste. } \\
\text { Analyses must be sufficient to allow disposal options to be accurately identified and } \\
\text { estimated. }\end{array}$} \\
\hline $\begin{array}{l}\text { Analytical } \\
\text { results }\end{array}$ & $\begin{array}{l}\text { Data packages of } \\
\text { analytical results; } \\
\text { Use analytical suite in } \\
\text { Table A. } 1-4 \text {; Require } \\
\text { TCLP if results are } \\
\text { >20X TCLP limits or if } \\
\text { PCB contamination } \\
\text { exceeds } 50 \text { ppm }\end{array}$ & $\begin{array}{l}\text { Appropriate sampling } \\
\text { techniques and approved } \\
\text { analytical methods will be } \\
\text { used; MRLs and minimum } \\
\text { detectable activities are } \\
\text { sufficient to provide } \\
\text { quantitative results for } \\
\text { comparison to disposal } \\
\text { requirements }\end{array}$ & $\begin{array}{l}\text { Sufficient } \\
\text { material must be } \\
\text { available for } \\
\text { analysis }\end{array}$ & $\begin{array}{c}\text { Quantitative - } \\
\text { Validated analytical } \\
\text { results will be } \\
\text { compared to disposal } \\
\text { criteria }\end{array}$ \\
\hline
\end{tabular}

Data types are discussed in the following text. All data to be collected are classified into one of three measurement quality categories: quantitative, semiquantitative, and qualitative. The categories for measurement quality are defined below.

\section{Quantitative Data}

Quantitative data measure the quantity or amount of a characteristic or component within the population of interest. These data require the highest level of $\mathrm{QA} / \mathrm{QC}$ in collection and measurement systems because the intended use of the data is to resolve primary decisions (i.e., Decision I or Decision II) and/or verifying closure standards have been met. Laboratory analytical data are generally considered quantitative.

\section{Semiquantitative Data}

Semiquantitative data indirectly measure the quantity or amount of a characteristic or component. Inferences are drawn about the quantity or amount of a characteristic or component because a correlation has been shown to exist between the indirect measurement and the results from a quantitative measurement. The $\mathrm{QA} / \mathrm{QC}$ requirements on semiquantitative collection and measurement systems are high but not as rigorous as a quantitative measurement system. Semiquantitative data contribute to decision making but are not used alone to resolve primary 
decisions. Field-screening data are generally considered semiquantitative. The data are often used to guide investigations toward quantitative data collection.

\section{Qualitative Data}

Qualitative data identify or describe the characteristics or components of the population of interest. The QA/QC requirements are the least rigorous for data collection methods and measurement systems. The intended use of the data is for information purposes, to refine conceptual models, and guide investigations rather than resolve primary decisions. This measurement of quality is typically assigned to historical information and data where QA/QC may be highly variable or not known. Professional judgement is often used to generate qualitative data.

Metrics provide a tool to determine if the collected data support decision making as intended. Metrics tend to be numerical for quantitative and semiquantitative data, and descriptive for qualitative data.

\section{A.1.4.2 Determine the Basis for the Preliminary Action Levels}

Industrial site and construction/remediation workers and military personnel (i.e., ground troops) may be exposed to contaminants through ingestion, inhalation, external (radiological), or dermal contact (absorption) of soil. Laboratory analytical results for soil will be compared to the following PALs to determine if COCs are present:

- $\quad$ EPA Region 9 Risk-Based PRGs for chemical constituents in industrial soils (EPA, 2002b)

- For detected COPCs without established PRGs, a similar protocol to that used by EPA Region 9 will be used in establishing an action level for those COPCs listed in IRIS (EPA, 2002c)

- Background concentrations for RCRA metals will be used instead of PRGs when natural background exceeds the PRG, as is often the case with arsenic on the NTS. Background is considered the mean plus two times the standard deviation of the mean for sediment samples collected by the Nevada Bureau of Mines and Geology throughout the Nevada Test and Training Range (NBMG, 1998; Moore, 1999).

- The TPH action limit of 100 ppm per the NAC 445A.2272 (NAC, 2002)

As discussed in Section A.1.1, the presence or extent of radiological contamination of soil within CAS 25-27-03 will not be addressed during the CAI. 


\section{A.1.4.3 Potential Sampling Techniques and Appropriate Analytical Methods}

As discussed in Section A.1.4.1, the collection, measurement, and analytical methods will be selected so the results will be generated for the PCBs as well as all other potential contaminants at CAS 25-27-03. This effort will include field screening, soil sampling and quick-turnaround laboratory analysis to determine the presence of COPCs and extent of identified COCs.

As discussed in Section A.1.1, the extent of radiological contamination of soil within CAS 25-27-03 will not be addressed during the CAI. For CAS 25-27-03, source characterization sampling and analysis are the focus of the DQO process. However, to support the disposal of IDW and potential future cleanup waste management issues, samples submitted for laboratory analysis will also be analyzed for gamma-emitting radionuclides, and based on the results, samples may also undergo strontium-90 and isotopic uranium analysis (see Table A.1-4). The radiological parameters are not considered COPCs and will not be used to define the extent of PCB, metal, or organic contamination at CAU 528. However, waste characterization sampling and analysis has been included to support the decision-making process for waste management, and to ensure an efficient field program. Specific analyses required for the disposal of IDW are identified in Section 5.0 of the CAIP.

\section{A.1.4.3.1 Field Screening}

Field-screening activities may be conducted for the following analytes and/or parameters:

- Alpha and Beta/Gamma Radiation - a handheld radiological survey instrument or method, may be used based on the possibility that radiologically contaminated soil or concrete may be present CAS 25-27-03. If determined appropriate, on-site gamma spectrometry may also be used to screen samples.

- VOCs - a photoionization detector (PID), or and equivalent instrument or method, may be used to conduct headspace analysis because VOCs are a common concern at the NTS and have not been ruled out based upon process knowledge at CAU 528 .

Based on the results of previous CAU investigations and common NTS practices, the aforementioned field-screening techniques may be applied during the Phase I and II sampling at CAS 25-27-03. These field-screening techniques will provide semiquantitative data that can be used to guide confirmatory soil sampling activities and waste management decisions. 


\section{A.1.4.3.2 Soil Sampling and Measurement Methods}

Hand sampling, augering, direct-push, excavation, drilling, or other appropriate sampling methods will be used to collect soil samples. Sample collection and handling activities will only be conducted in accordance with approved procedures. It may be appropriate to use excavation in selected areas to determine if contaminated soil has been covered with clean fill.

\section{A.1.4.3.3 Analytical Program}

The analytical program for CAS 25-27-03 shown in Table A.1-4 has been developed based on the suspected-contamination information presented in Section A.1.1.

Table A.1-4

Analytical Program for CAU 528

\begin{tabular}{||l||}
\hline \multicolumn{1}{|c|}{ Analyses $^{\text {a }}$} \\
\hline \hline Organics \\
\hline Total Petroleum Hydrocarbons (DRO and GRO) \\
\hline Volychlorinated Biphenyls (PCBs) \\
\hline Semivolatile Organic Compounds (SVOCs) \\
\hline \hline Resource Conservation and Recovery Act Metals ${ }^{\mathrm{b}}$ and Beryllium \\
\hline \hline Radionuclides \\
\hline Gamma Spectrometry \\
\hline Isotopic Uranium $^{\mathrm{d}}$ \\
\hline Strontium-90 \\
\hline
\end{tabular}

alf the volume of material is limited, prioritization of the analyses will be necessary.

${ }^{\mathrm{b}}$ May also include Toxicity Characteristic Leaching Procedure metals if sample is collected for IDW disposal or future waste management issues

${ }^{c}$ Radionuclides will only be analyzed in support of IDW disposal and future waste management issues.

${ }^{d}$ All submitted samples will be analyzed by gamma spectrometry, and selected samples also will be analyzed for strontium-90 and isotopic uranium

DRO = Diesel-Range Organics

$\mathrm{GRO}=$ Gasoline-Range Organics 
Radionuclides have been included in the analytical suite for selected samples to support IDW disposal and potential future waste management issues. The radionuclides are not intended to drive the nature and extent determinations under this investigation. The critical COPCs for CAU 528 are TPH and PCBs. Polychlorinated biphenyls are known to be present within the CAS boundaries and TPH has a reasonable probability of being present at CAS 25-27-03 based on process knowledge, experience at other similar CASs, and other historic information. The critical COPCs are given greater importance in the decision-making process relative to noncritical COPCs. For this reason, more stringent performance criteria are specified for critical analyte DQIs (Section 6.0 of the CAIP). Noncritical COPCs are defined as classes of contaminants that include all the analytes reported from the respective analytical methods that have PALs. The noncritical COPCs also aid in reducing the uncertainty concerning the history and potential releases from the CAS and help in the accurate evaluation of potential contamination. If a COPC, either critical or noncritical, is detected in any sample at a concentration above the respective PAL, the COPC will be identified as a COC. During Phase II sampling and analysis, all COCs are considered critical parameters Sections 3.0 and 6.0 of the CAIP provide the analytical methods and laboratory requirements (e.g., detection limits, precision, and accuracy) to be followed during this CAI. Sample volumes are laboratory- and method-specific and will be determined in accordance with laboratory requirements. Analytical requirements (e.g., methods, detection limits, precision, and accuracy) are specified in the Industrial Sites QAPP (NNSA/NV, 2002), unless superseded by the CAIP. These requirements will ensure that laboratory analyses are sufficient to detect contamination in samples at concentrations exceeding the MRL. Specific analyses, if any, required for the disposal of IDW are identified in Section 5.0 of the CAIP.

For sampling performed to define the extent of contamination (Decision II) at CAS 25-27-03, samples will be collected and analyzed only for COCs identified in samples collected to resolve Decision I. However, if extent samples are collected prior to nature-of-contamination data becoming available, the extent samples will be analyzed for the full list parameters given in Table A.1-4. For samples collected to define the extent of contamination, critical analytes are the COCs identified during Decision I (Phase I) activities that exceed PALs. 


\section{A.1.5 Step 4 - Define the Study Boundaries}

The purpose of this step is to define the target population of interest, specify the spatial and temporal features of that population that are pertinent for decision making, determine practical constraints on data collection, and define the scale of decision making relevant to target populations for Decision I and Decision II.

\section{A.1.5.1 Define the Target Population}

Decision I target populations represent locations within the CAS that contain COCs, if present. Decision II target populations are areas within the CAS where COC concentrations are less than PALs and are contiguous to areas of COC contamination. The target populations are dependent upon the CSM developed for CAS 25-27-03. These target populations represent locations within the CAS that, when sampled, will provide sufficient data to resolve the primary problem statement (Section A.1.3.1).

\section{A.1.5.2 Identify the Spatial and Temporal Boundaries}

Spatial (geographic) boundaries are defined as the vertical or horizontal boundaries beyond which the $\mathrm{CSM}$ and/or the scope of the investigation will require reevaluation. Intrusive sampling activities are not intended to extend into the boundaries of neighboring areas of environmental concern (e.g., other CASs). The horizontal boundaries at CAS 25-27-03 reflect the area of concern (i.e., the suspected lateral extent of surface contamination) where COCs potentially may exist. Although radiological contamination related to the TCC testing activities may be "superimposed" on the CAS 25-27-03 footprint, the contamination will not be investigated by the CAU $528 \mathrm{CAI}$. As mentioned previously, radiological concerns are related to IDW disposal and future waste management issues. The spatial boundaries for CAS 25-27-03 are listed in Table A.1-5. The horizontal boundaries at CAS 25-27-03 reflect the uncertainty in the locations where CAS-specific contaminants may be present within TCC.

Temporal boundaries are time constraints due to time-related phenomena, such as weather conditions, seasons, activity patterns, etc. Significant temporal constraints due to weather conditions are not expected; however, snow events may affect site activities during winter months. Moist weather may place constraints on sampling and field-screening of contaminated soils because of the attenuating effect of moisture in samples. There are no time constraints on collecting samples. 
Table A.1-5

Spatial Boundaries for CAU 528, CAS 25-27-03

\begin{tabular}{|l|l|}
\hline \multicolumn{2}{|c|}{ Sorizontal } \\
\hline \multicolumn{2}{|c|}{ Hotial Boundary } \\
\hline \hline $\begin{array}{l}\text { A maximum 100-ft buffer around the TCC } \\
\text { fencing on the north, east, and south sides of } \\
\text { TCC. The edge of Topopah Wash along the } \\
\text { western side of TCC }\end{array}$ & A maximum of 10 $\mathrm{ft}$ bgs \\
\hline $\begin{array}{l}\text { A maximum of } 50 \mathrm{ft} \text { around the concrete pad to } \\
\text { include the earthen berm }\end{array}$ & A maximum of 10 $\mathrm{ft}$ bgs \\
\hline
\end{tabular}

\section{A.1.5.3 Identify Practical Constraints}

Nevada Test Site-controlled activities may affect the ability to characterize the CAS, although the TCC is inactive and abandoned. The primary practical constraints to be encountered at CAS 25-27-03 would be the presence of underground utilities. Utility constraints are subject to change as additional information is collected prior to the commencement of investigation activities, and will be appropriately documented. Locations where intrusive activities are planned will be surveyed for utilities prior to field activities in accordance with the SSHASP.

\section{A.1.5.4 Define the Scale of Decision Making}

For CAS 25-27-03, the scale of decision making for Decision I is defined as CAS 25-27-03. The scale of decision making for Decision II is defined as the extent of COC contamination originating from CAS 25-27-03.

\section{A.1.6 Step 5-Develop a Decision Rule}

This step integrates outputs from the previous steps, with the inputs developed in this step into a decision rule ("If..., then...") statement. This decision rule describes the conditions under which possible alternative actions would be chosen. 


\section{A.1.6.1 Specify the Population Parameter}

The population parameter for Phase I data collected from biased sample locations is the maximum observed concentration of each $\mathrm{COC}$ within the target population.

The population parameter for Phase II data will be the observed concentration of each unbounded $\mathrm{COC}$ in any sample.

\section{A.1.6.2 Choose an Action Level}

Action levels are defined as the PALs, which are specified in Section A.1.4.2.

\section{A.1.6.3 Decision Rule}

If the concentration of any COPC in a target population exceeds the PAL for a COPC in a Phase I sample, then that COPC is identified as a COC, and the extent of contamination (Phase II) sampling will be conducted. If the Site Supervisor determines that an indicator of contamination is present, then Phase II sampling may be conducted before the results of Phase I sampling are available. If all COPC concentrations are less than the corresponding PALs, then the decision will be no further actions. Based on PA sampling results, the CAI at CAS 25-27-03 will include extent (Phase II) sampling for PCBs during the initial field effort.

If the observed population parameter of any COC in a Phase II sample exceeds the PALs, then additional samples will be collected to complete the Phase II evaluation. If all observed COC population parameters are less than PALs, then the decision will be that the extent of contamination has been defined in the lateral and vertical directions.

If contamination is inconsistent with the CSM or extends beyond the identified spatial boundaries, then work will be suspended and the investigation strategy will be reevaluated. If contamination is consistent with the CSM and is within spatial boundaries, then the decision will be to continue sampling to define extent. 


\section{A.1.7 Step 6 - Specify the Tolerable Limits on Decision Errors}

The sampling approach for the investigation relies on biased sampling locations; therefore, statistical analysis is not appropriate. Only validated analytical results (quantitative data) will be used to determine if COCs are present (Phase I) or the extent of a COC (Phase II), unless otherwise stated. The baseline condition (i.e., null hypothesis) and alternative condition for Phase I are:

- Baseline condition - A COC other than PCBs is present.

- Alternative condition - A COC other than PCBs is not present.

The baseline condition (i.e., null hypothesis) and alternative condition for Phase II are:

- Baseline condition - The extent of a COC including PCBs has not been defined.

- Alternative condition - Extent of a COC including PCBs has been defined.

Decisions and/or criteria have an alpha (false negative) or beta (false positive) error associated with their determination (discussed in the following subsections). Since quantitative data compared to action levels on a point-by-point basis, statistical evaluations of the data such as averages or confidence intervals are not appropriate.

\section{A.1.7.1 False Negative (Rejection) Decision Error}

The false negative (rejection of the null hypothesis or alpha error) decision error would mean:

- Deciding that a COC is not present when it actually is (Decision I), or

- Deciding that the extent of a COC has been defined when it actually has not (Decision II).

In both cases, this would result in an increased risk to human health and environment.

For Decision I, a false negative decision error (where the consequences are more severe) is controlled by meeting the following criteria:

- Having a high degree of confidence that the sample locations selected will identify COCs if present anywhere within the CAS

- Having a high degree of confidence that analyses selected (both field screening and confirmatory laboratory) will be sufficient to detect any COCs present in the sampled media and that the detection limits are adequate to ensure an accurate quantification of the COCs. 
For Decision II, the false negative decision error is reduced by:

- Having a high degree of confidence that the sample locations selected will identify the extent of COCs

- Having a high degree of confidence that analyses conducted will be sufficient to detect any COCs present in the samples

- Having a high degree of confidence that the dataset is of sufficient quality and completeness To satisfy the first criterion for both decisions, Phase I samples will be collected in areas most likely to be contaminated by PCBs; any other COPCs, and Phase II samples will be collected in areas that represent the lateral and vertical extent of COCs including PCBs. The following characteristics are considered during both phases to accomplish the first criterion:

- Source and location of release

- Chemical nature and fate properties

- Physical properties and migration/transport pathways

- Hydrologic drivers

These characteristics were considered during the development of the CSMs. The biasing factors listed in Table A.1-3 and Section A.1.8.1 will be used to further ensure that these criteria are met.

To satisfy the second criterion for Decision I, all samples used to define the nature of contamination will be analyzed for the parameters listed in Section A.1.4.3.3 using analytical methods that are capable of producing quantitative data at concentrations equal to or below PALs (unless stated otherwise in the CAIP). To satisfy the second criterion for Decision II, Phase II samples will be analyzed for those parameters that identified unbounded COCs.

To satisfy the third criterion for Decision II, the entire dataset, as well as individual sample results, will be assessed against the DQIs of precision, accuracy, comparability, completeness, and representativeness defined in the Industrial Sites QAPP (NNSA/NV, 2002). The goal for the completeness DQI is that 100 percent of the critical COPC results are valid for every sample. Critical COPCs are defined as those contaminants that are known or expected to be present within a CAS (Section A.1.4.3.3). In addition, sensitivity has been included as a DQI for laboratory analyses. Site-specific DQIs are discussed in more detail in Section 6.0 of the CAIP. Strict adherence to established procedures and QA/QC protocols also protects against false negatives. 


\section{A.1.7.2 False Positive Decision Error}

The false positive (acceptance of the null hypothesis or beta) decision error would mean:

- Deciding that a COC is present when it actually is not (Decision I)

- Accepting that the extent of a COC has not been defined when it really has (Decision II)

These errors result in increased costs for unnecessary characterization or corrective actions.

The false positive decision error is controlled by protecting against false positive analytical results. False positive results are typically attributed to laboratory and/or sampling/handling errors. Quality assurance (QC) samples such as field blanks, trip blanks, laboratory control samples, and method blanks minimize the risk of a false positive analytical result. Other measures include proper decontamination of sampling equipment and using certified clean sample containers to avoid crosscontamination.

\section{A.1.7.3 Quality Assurance/Quality Control}

Field screening equipment will be calibrated and checked in accordance with the manufacturer's instructions or approved.

Quality control samples will be collected as required by the Industrial Site QAPP (NNSA/NV, 2002) and in accordance with established procedures. These procedures apply to both the quick-turnaround and standard analyses. The required QA field samples include:

- Trip blanks (1 per sample cooler containing environmental VOC samples)

- Equipment blanks (1 per sampling event for each type of decontamination procedure)

- Source blanks (1 per source lot per sampling event)

- Field duplicates (minimum of 1 per matrix per 20 environmental samples or 1 per CAS if less than 20 collected)

- Field blanks (minimum of 1 per 20 environmental samples, or 1 per CAS if less than 20 collected)

- Matrix spike/matrix spike duplicate (minimum of 1 per matrix per 20 environmental samples or 1 per CAS if less than 20 collected, not required for all radionuclide measurements) 
Additional QC samples may be submitted based on site-specific conditions.

\section{A.1.8 Step 7 - Optimize the Design for Obtaining Data}

This section presents an overview of the resource-effective strategy planned to obtain the data required to meet the project DQOs developed in previous six steps. Section A.1.8.1 provides general investigation strategy, and Section A.1.8.2 provides the detailed sampling approach to resolve the decision statements for CAU 528. As additional data or information is obtained, this step will be reevaluated and refined, if necessary, to reduce uncertainty and increase the confidence that the nature and extent of contamination is accurately defined.

\section{A.1.8.1 General Investigation Strategy}

The initial activities to be conducted will be a visual inspection and photodocumentation of the area of CAS 25-27-03. The visual inspection will provide additional biasing factors for locating soil samples and to identify any potential conditions that may affect sampling and sample locations.

Following visual inspection, approximately 40 surface soil sample ( 0 to $0.5 \mathrm{ft}$ bgs) locations will be identified and collected for quick-turnaround PCB laboratory analysis. The selection of these locations considers the locations of the previous sampling results where PCBs are know to be present. The PCB quick-turnaround results, along with existing analytical data, will be used to select locations where additional Phase I (Decision I) confirmatory samples may be necessary. Phase I (Decision I) surface and shallow subsurface soil samples will be collected for laboratory analysis of the parameters identified in Section A.1.4.3.3.

Phase II (step-out) sampling locations at CAS 25-27-03 will be selected based on the outer boundary sample locations where a $\mathrm{COC}$ is detected in the Phase I confirmatory samples. Phase II locations will also be selected based on pertinent features of the CSM and the other biasing factors. If biasing factors indicate a COC potentially extends beyond planned Phase II sample points, locations may be modified or additional Phase II samples may be collected from incremental step-out locations. Both surface and subsurface soil samples may be collected and analyzed to determine the extent of a COC.

Contaminants determined not to be present in Phase I samples may be eliminated from Phase II analytical suites. In general, samples submitted for off-site analysis will be those that define the 
nature (Phase I) and extent (Phase II) of COCs. This effort will apply to the lateral and vertical extent of the COCs.

\section{A.1.8.2 Detailed Investigation Strategy}

The initial activities to be conducted will be a visual inspection and photodocumentation of CAS 25-27-03. The visual inspection will focus on identifying evidence of contamination at the Substation \#3 concrete pad resulting from a failure or leak from the transformers. The soils surrounding TCC that may have been subjected to dust suppression activities will also be inspected for discoloration or other signs of contamination. The information generated during these initial activities will be used to provide additional biasing factors for the placement of field screening and confirmatory soil samples.

Following visual inspection, surface soil sample locations will be established for quick-turnaround analysis. This effort will use the data from previously collected samples and other biasing factors to identify sampling points along the edge of the TCC concrete pad. Previous analytical data may be used in the decision process if the data meet the quality criteria specified in this DQO process. Additional surface soil sampling points will be established at 25 - to 50-ft lateral step-out locations moving away from the TCC pad toward the fence along the northern, eastern, and southern side of the facility. Step-out locations also will be identified moving west from the TCC concrete pad toward the edge of Topopah Wash. No sampling is planned within the wash. To determine the presence of contaminants that may have potentially originated from the Substation \#3 concrete pad, surface soil screening points will be located at two 15 - to 20 -ft intervals from each side of the Substation \#3 concrete pad and on and around the earthern berm. Figure A.1-5 shows a generalized sampling plan for CAU 528. It is anticipated that surface soil samples from approximately 40 to 50 locations will be collected for quick-turnaround laboratory PCB analysis; the actual number will depend on the site-specific conditions and the results of the initial group of quick-turnaround analyses.

The following are the biasing factors that currently have been identified for consideration in the selection of the surface soil field-screening sample locations:

- Aerial photograph review and evaluation

- Visual indicators (e.g., staining, topography, areas of preferential surface runoff)

- Existing site-specific analytical data (PA and CAU 262 sampling data) 


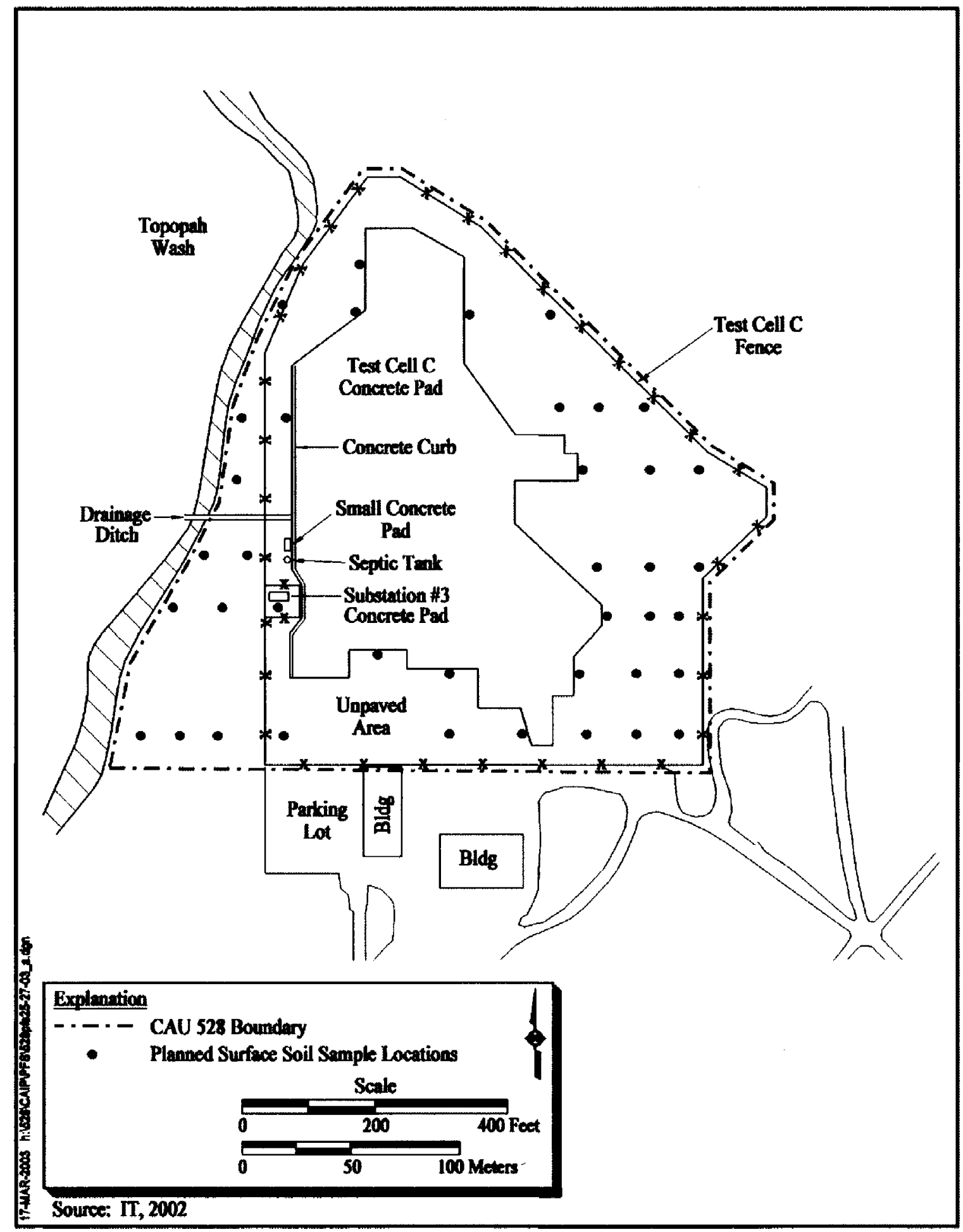

Figure A.1-5

CAU 528, CAS 25-27-03 Potential Surface Soil Sample Locations 
- Known or suspected sources and locations of release

- Process knowledge and experience at similar sites

- Information and/or data from adjacent CASs

- Geologic and/or hydrologic conditions

- Physical and chemical characteristics of suspected contaminants

The samples selected for the confirmation of Phase I (approximately 25 percent of total samples submitted for quick-turnaround PCB analysis) will be analyzed for the full suite of analyses presented in Section A.1.4.3.3. Selection of the Phase II (extent) samples will follow the same procedure but are expected to require less quick-turnaround analyses.

These analyses will accurately determine the concentrations of detected PCBs and other COPCs and identify additional COCs. Samples will be submitted to support Decision I (from worst-case locations) and to support Decision II (confirm the horizontal extent of contamination). Data collected during previous sampling events, quick-turnaround results, and the other biasing factors listed above will be used to select locations where the presence of COCs is or is not suspected (Decision I and Decision II, respectively). If necessary, additional surface soil samples will be submitted for laboratory analysis to ensure that the extent of contamination is defined using quantitative data. Lateral step-outs distances will generally be consistent with the 25 - to 50 -ft spacing discussed above but can be adjusted by the Site Supervisor based on site-specific information obtained during the initial sampling effort.

Where PCBs exceed the PALs in surface soil based on quick-turnaround analyses and previous sampling results, shallow subsurface soil samples will be collected from selected locations to define the vertical extent of contamination. To determine if clean soil has been placed over contaminated subsoil, shallow subsurface soil samples will also be collected from approximately 25 percent of the locations where PCBs were not detected by quick-turnaround or confirmatory analysis in the surface samples.

The sampled depth intervals at subsurface locations will be based on biasing factors such as presence of debris, staining, odor, FSRs, or professional judgement. Test pits may be excavated to further evaluate the potential that clean soil was backfilled over contamination and to assist in the collection of biased subsurface soil samples. For subsurface sampling locations, generally two consecutive soil samples with results below field-screening action levels are required to define the vertical extent of 
contamination. Generally, the uppermost "clean" sample from each location will be submitted for laboratory analysis.

At locations where Phase I analytical results show PCB concentrations in soil equal to or greater than $50 \mathrm{ppm}$, step-out (both vertical and horizontal) samples will be collected during the Phase II sampling to delineate the extent of the potential hot spots. Step-outs from PCB hot spots will continue until the extent of PCB concentrations greater than or equal to $25 \mathrm{ppm}$ is delineated.

Surface soil samples will be collected by hand. Sonic drilling, hollow-stem auger drilling, direct-push, handheld augers, or excavation will be used, as appropriate, to collect subsurface samples. Samples for IDW and waste characterization purposes may also be collected at CAS 25-27-03.

Due to the nature of buried features possibly present (e.g., structures, buried debris, and utilities), sample locations may be relocated, based upon the review of engineering drawings, and information obtained during the site visit. However, the new locations will meet the decision needs and criteria stipulated in Section A.1.4.1.

\section{A.1.9 References}

DOE/NV, see U.S. Department of Energy, Nevada Operations Office.

EPA, see U.S. Environmental Protection Agency.

IT, see IT Corporation.

IT Corporation. 2002. Project file for CAU 528, CAS 25-27-03, and field forms. Las Vegas, NV.

LASL, see Los Alamos Scientific Laboratory.

Los Alamos Scientific Laboratory. 1967. Decontamination of Test Cell "C" at the Nuclear Rocket Development Station After a Reactor Accident, LA-3633-MS. Los Alamos, NM.

Moore, J., Science Applications International Corporation. 1999. Memorandum to M. Todd (SAIC) entitled, "Background Concentrations for NTS and TTR Soil Samples," 3 February.

Las Vegas, NV: IT Corporation.

NAC, see Nevada Administrative Code. 
NBMG, see Nevada Bureau of Mines and Geology.

NNSA/NV, see U.S. Department of Energy, National Nuclear Security Administration Nevada Operations Office.

Nevada Administrative Code. 2002. NAC 445A.2272, "Contamination of Soil: Establishment of Action Levels." Carson City, NV.

Nevada Bureau of Mines and Geology. 1998. Mineral and Energy Resource Assessment of the Nellis Air Force Range, Open-File Report 98-1. Reno, NV.

Tinney, J. 2001. Contamination of the Topopah Wash from the Kiwi Transient Nuclear Test, the Phoebus la Accident, and Phoebus 2A Tests. Prepared for IT Corporation. Las Vegas, NV.

USGS, see U.S. Geological Survey.

U.S. Department of Energy, National Nuclear Security Administration Nevada Operations Office. 2002. Industrial Sites Quality Assurance Project Plan, Nevada Test Site, Nevada, DOE/NV--372-Rev. 3. Las Vegas, NV.

U.S. Department of Energy, Nevada Operations Office. 1996. Final Environmental Impact Statement for the Nevada Test Site and Off-Site Locations in the State of Nevada, DOE/EIS 0243. Las Vegas, NV.

U.S. Department of Energy, Nevada Operations Office. 1998. Nevada Test Site Resource Management Plan, DOE/NV--518. Las Vegas, NV.

U.S. Department of Energy, Nevada Operations Office. 2001. Corrective Action Decision Document for Corrective Action Unit 262: Area 25 Septic Systems and Underground Discharge Point, Nevada Test Site, Nevada, DOE/NV--744, Rev. 4. Las Vegas, NV.

U.S. Environmental Protection Agency. 2000. Memorandum from S.J. Smucker to PRG table mailing list regarding Region LX Preliminary Remediation Goals (PRGs), 1 August. San Francisco, CA.

U.S. Environmental Protection Agency. 2002a. Guidance for Quality Assurance Project Plans, EPA $Q A / G-5, E P A / 240 / R-02 / 009$. Washington, D.C.

U.S. Environmental Protection Agency. 2002b. Region IX Preliminary Remediation Goals (PRGs). Prepared by S.J. Smucker. San Francisco, CA.

U.S. Environmental Protection Agency. 2002c. Integrated Risk Information System (IRIS) Database, as accessed at http://www.epa.gov/iris/index.html on October 16, 2002. 
Date: September 2006

\section{APPENDIX B}

\section{SAMPLE ANALYTICAL RESULTS}


Closure Report - CAU 528

Section: Appendix B

Revision; 0

Date: September 2006

THIS PAGE INTENTIONALLY LEFT BLANK 


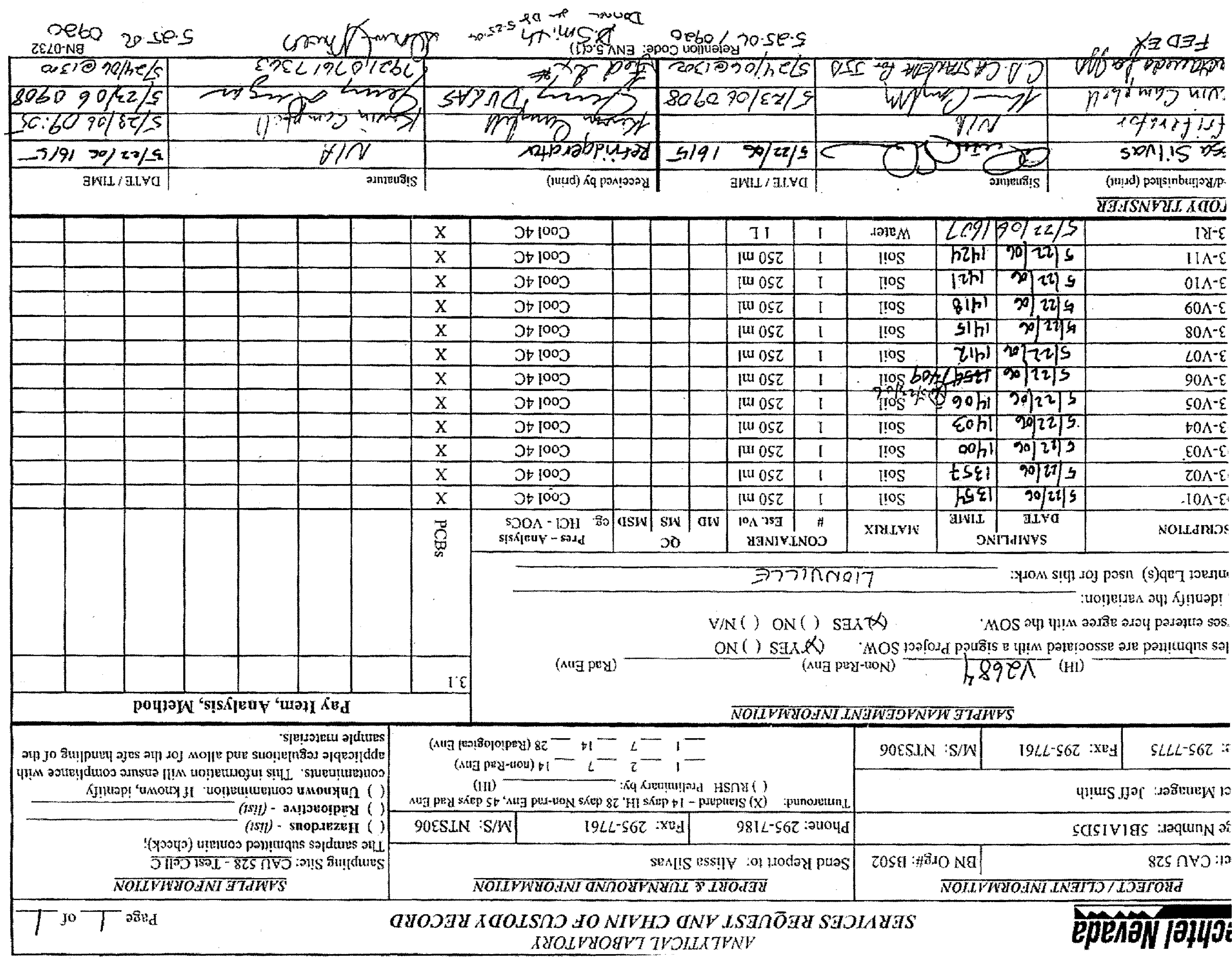


Cust ID: $252703-$ vo1

Sample

Information

$\begin{array}{rcc}\text { RFW\#: } & 001 & \text { 00I WS } \\ \text { Matrix: } & \text { SOIL } & \text { SOIL } \\ \text { D.F.: } & 10.0 & 10.0 \\ \text { Units: } & \text { UG/KG } & \text { UG/KG }\end{array}$

\section{$253703-V 01$}

$001 \mathrm{MSD}$

SOTL

10.0

$\mathrm{UG} / \mathrm{KG}$

\section{$252703-102$}

\section{2}

SOIL

50.0

$\mathrm{UG} / \mathrm{KG}$
$252703-\mathrm{V03}$

003

SOII

5.00

$\mathrm{UG} / \mathrm{KG}$
$252703-V 04$

$119 * *$

114

110

$159 *$

$124 * \frac{8}{4}$

$\begin{array}{cccc}122 & : & 670 & \mathrm{U} \\ 140 & \mathrm{U} & 670 & \mathrm{U}\end{array}$

$140 \mathrm{U} \quad 670 \mathrm{U}$

$140 \mathrm{U} \quad 670 \mathrm{U}$

$140 \mathrm{U} \quad 670 \mathrm{U}$

$140 \mathrm{U} 670 \mathrm{U}$

I. $670 \mathrm{U}$

$2400 \quad 7200$

$140 \mathrm{U}$

$\begin{array}{rlrl}68 & \mathrm{U} & 280 & \mathrm{U} \\ 68 & \mathrm{U} & 280 & \mathrm{U} \\ 6 \mathrm{~B} & \mathrm{U} & 280 & \mathrm{U} \\ 68 & \mathrm{U} & 280 & \mathrm{U} \\ 68 & \mathrm{U} & 280 & \mathrm{U} \\ 68 & \mathrm{U} & 280 & \mathrm{U} \\ 68 & \mathrm{U} & 280 & \mathrm{U} \\ 400 & & 1900 & \\ 68 & \mathrm{U} & 280 & \mathrm{U}\end{array}$

Arochlor -1262

$140 \quad 0$
1500

$140 \quad 0$

$340 \quad 0$

$670 \quad 0$

$68 \mathrm{U}$

$280 . \mathrm{U}$

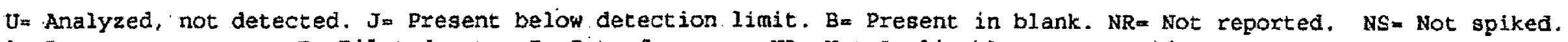

$z=$ Percent recoverY. $D=$ Diluted out. $I=$ Interference. NA $=$ Not Appilcable. $*=$ Outside of EPA CLP QC

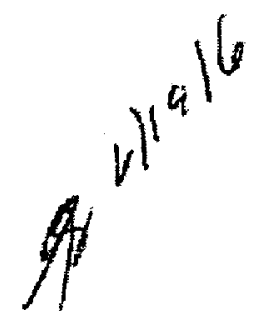




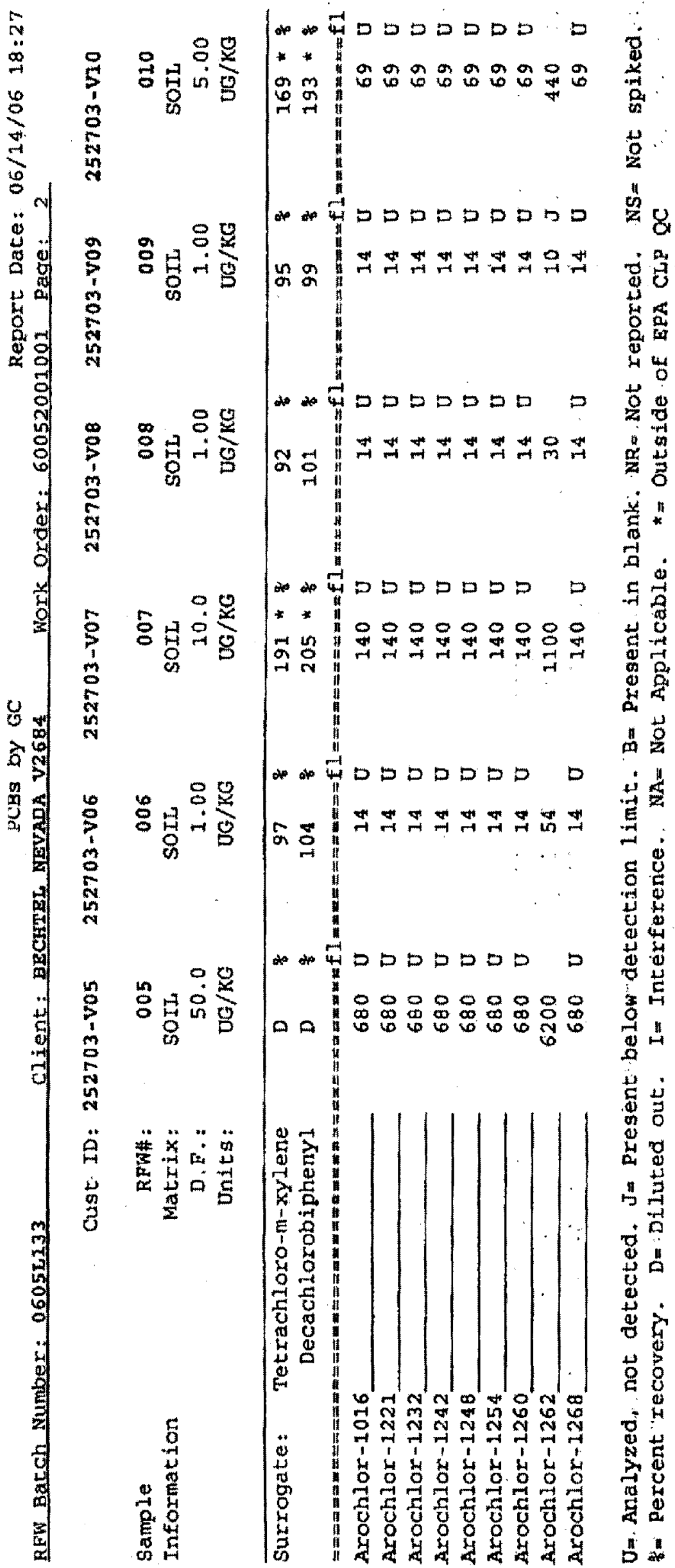



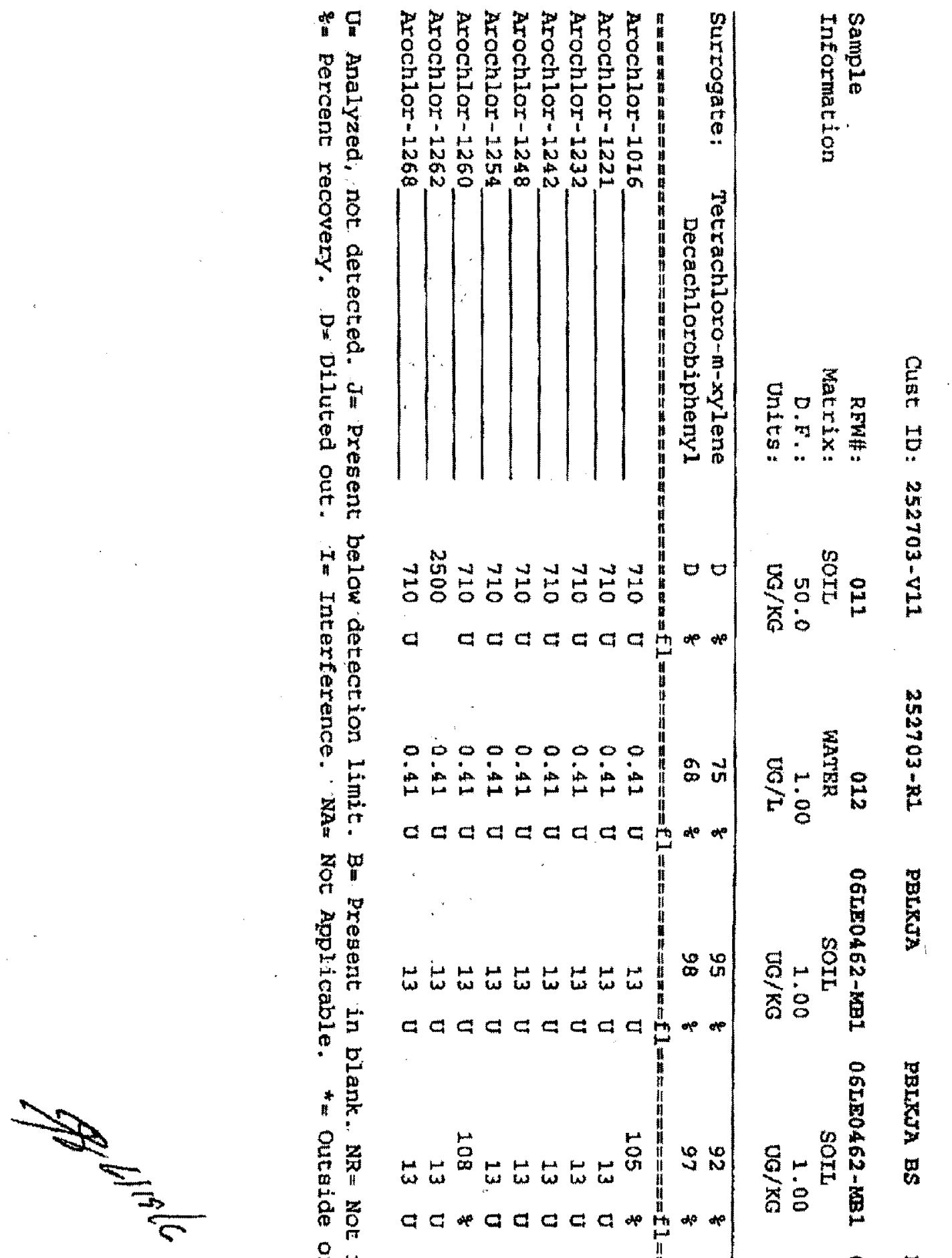

窟

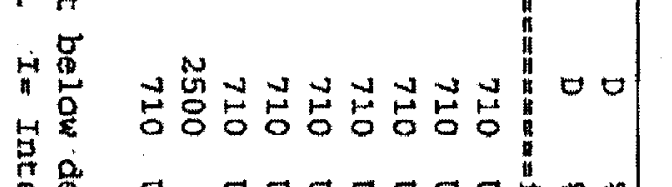

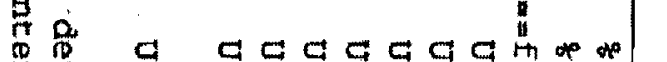

索

悹

要

$\because$

1.

g.

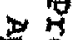

g

.

:

is.

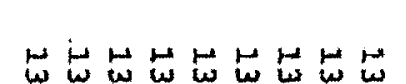

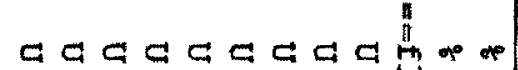

$\stackrel{\circ}{0}$

*

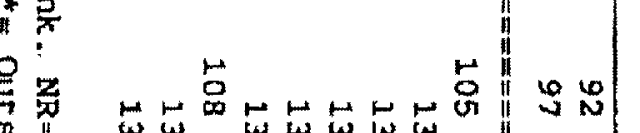

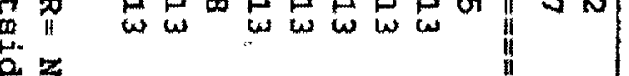

政

द 9 a c c द व

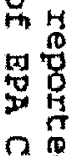

t?

8

000000000

is is is is is 1109

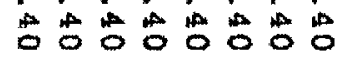

accac日aa유

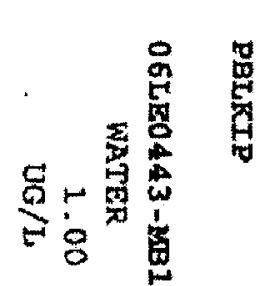

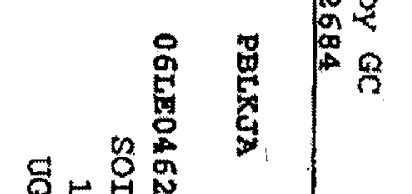

照

5

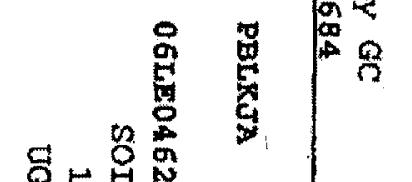

敢品

站

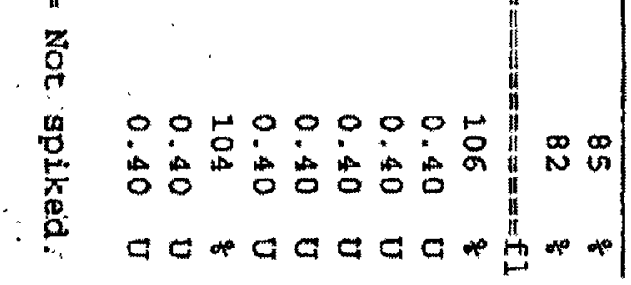

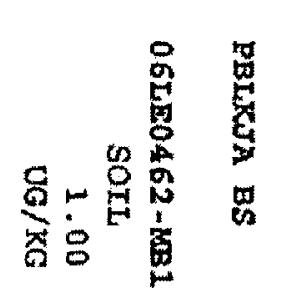

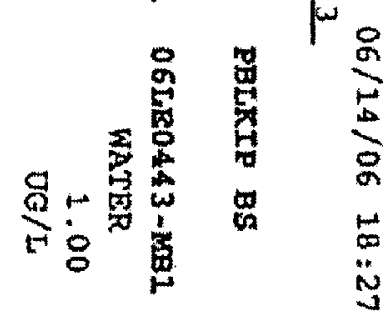




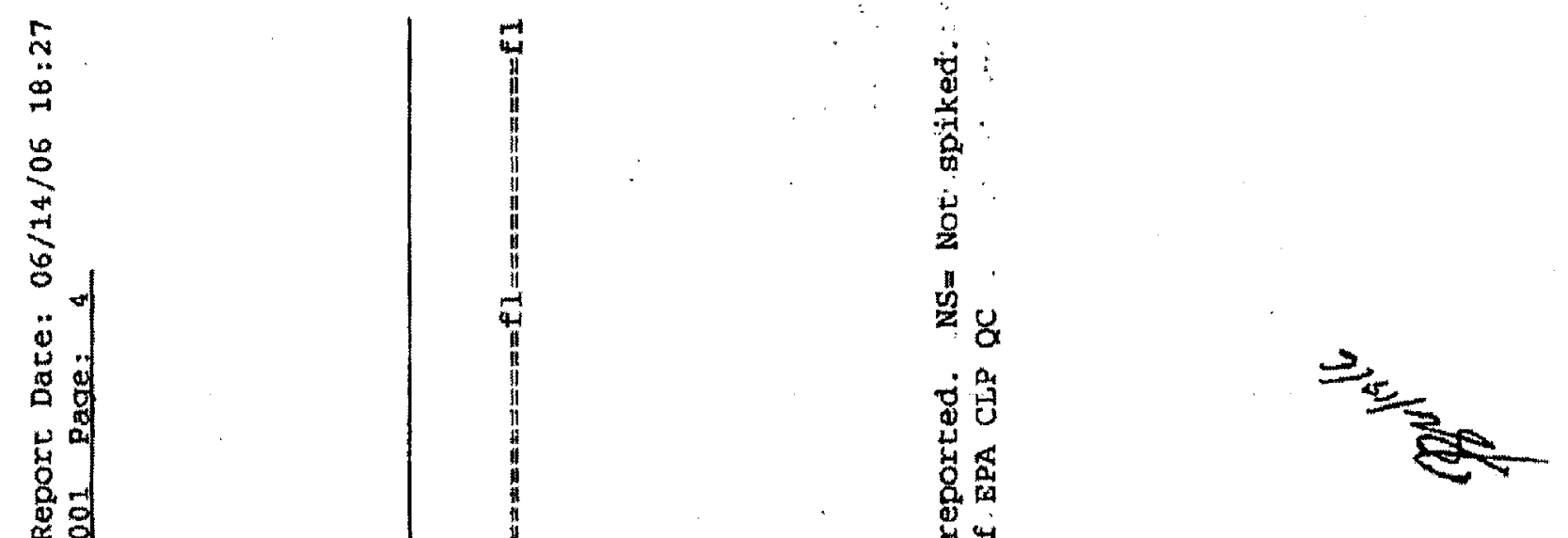

$U$

a

岁

茓驾

䓛*

营

둥

동

है

总谷

a

ํㅐ을

占告

E

웜

it

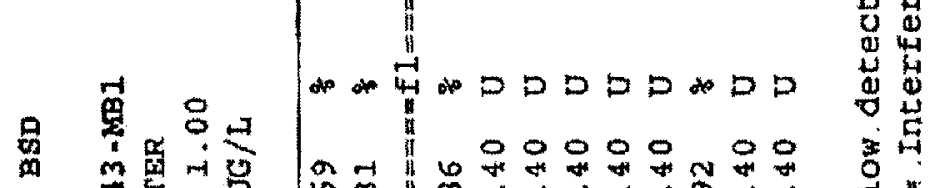

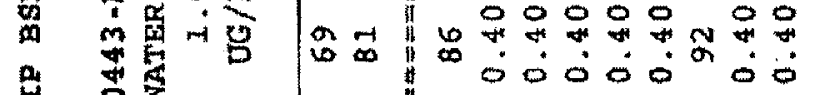

䒴落

-

苋:

岂 岁

$\ddot{i} \quad \ddot{1} \ddot{z} \ddot{g}$

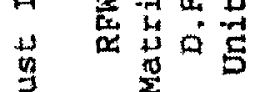

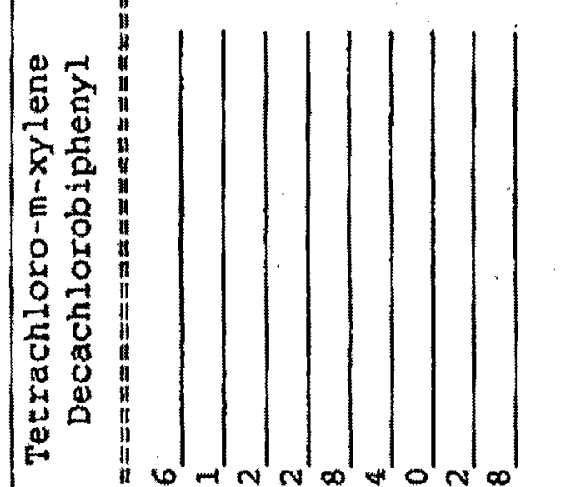

崖

a.

$\rightarrow \stackrel{-1}{-1}$

बृ

岂

岁

$+9$

马 11 웠

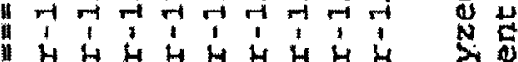

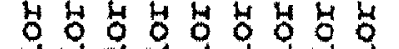

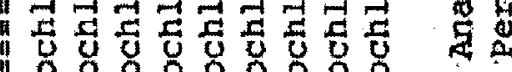

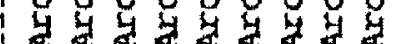

मे 
WATER PESTICTDE SURROGATE RECOVERY

Lab Name: Lionvi1le Labs, Inc.

Contract: $\quad 0052-01-01$

Case No.: BECHTEL NEXADA V2684

REW Lot No.: 06052133

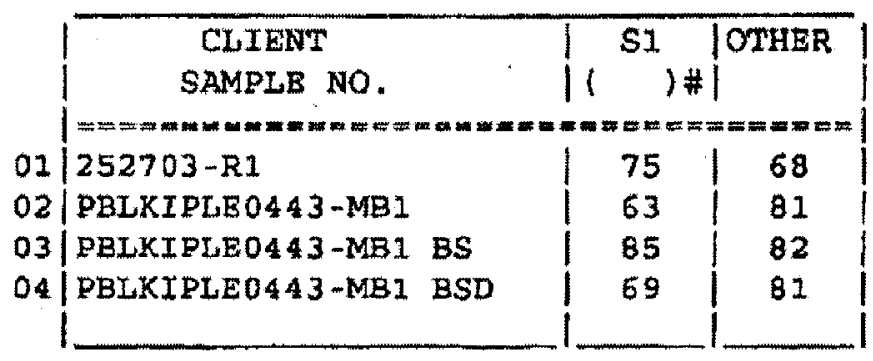

ADVISORY

QC LIMITS

S1 () - Tetrachloro-m-xylene

(27-129)

s2 ( ) Decachlorobiphenyl

$(22-126)$

\# Column to be used to flag recovery values

* Values outside of QC limits

D surrogates diluted out

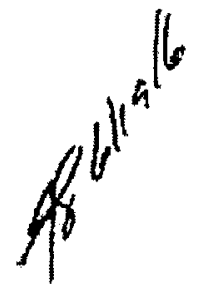


$2 F$

SOIL PESTICIDB SURROGATB RECOVERY

Lab Name: Lionville Labs, Inc.

Contract: $0052-01-01$

Case No.: BECHTEL NEVADA V2684

RFW LOt NO.: $0605 \mathrm{~L} 133$

\begin{tabular}{|c|c|c|c|c|}
\hline & CIIENT & s1 & OOTHER & \\
\hline & SAMPEE NO. & ) & & \\
\hline & 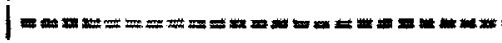 & & $m=m=-$ & \\
\hline 01 & 252703-v0I & 49 & 64 & \\
\hline 02 & 252703-Vo1MS & 108 & 134 & $\star$ \\
\hline 03 & 252703-VO1MSD & $219 *$ & 142 & * \\
\hline 04 & $252703-v 02$ & 114 & 159 & * \\
\hline 05 & 252703 - V03 & 210 & 124 & * \\
\hline 06 & $1252703-\mathrm{VOA}$ & 82 & 111 & \\
\hline 07 & |252703-V05 & $\mathbf{D}$ & $\mathrm{D}$ & \\
\hline 08 & $252703-V 06$ & 97 & 104 & \\
\hline 09 & $252703-v 07$ & $191 *$ & 205 & $\star$ \\
\hline 10 & $252703-V 08$ & 92 & 101 & \\
\hline 11 & $252703-\mathrm{V09}$ & 95 & 99 & \\
\hline 12 & $252703-v 10$ & $169 *$ & 193 & * \\
\hline 13 & $252703-V 11$ & D. & D & \\
\hline 14 & | PBLKJALB0462-MBI & 95 & 98 & \\
\hline 15 & | PBLKJALE0462-MB1 BS & 92 & 97 & \\
\hline
\end{tabular}

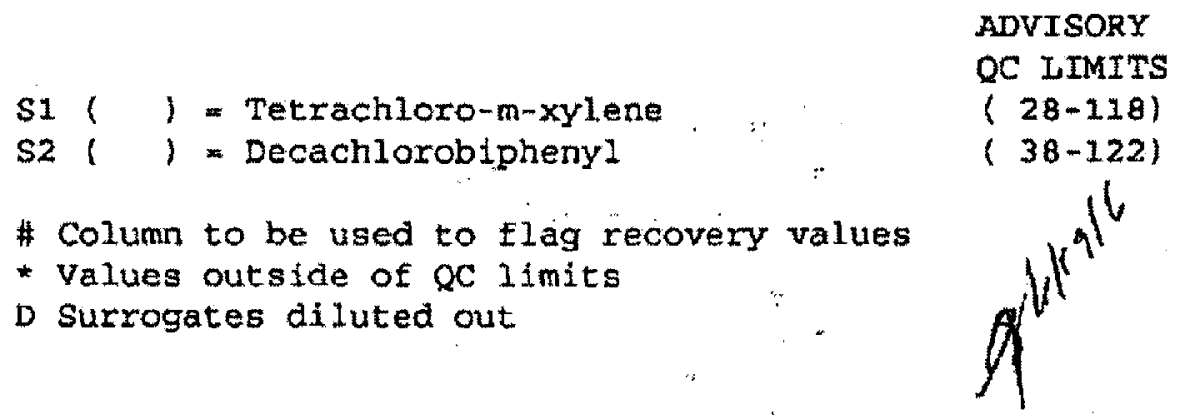


SOIL PESTICIDE MATRIX SPIKE/MATRIX SPIKE DUPLICATE RECOVERY

Lab Name: Lionvilie Labs. Inc.

Case NO.: BECHTEL NEVADA V2684

MATRIX Spike - Sample No.: 252703-V01
Concract: $\quad 0052-01-01$

RFW LOt NO.: 0605L133-001

\begin{tabular}{|c|c|c|c|c|c|c|}
\hline COMPOUND & $\mid \begin{array}{c}\text { SRIKE } \\
\text { ADDED } \\
\text { UG } / K G\end{array}$ & $\left\{\begin{array}{c}\text { SAMPLE } \\
\text { CONCENTRATION } \\
\text { UG/KG }\end{array}\right.$ & $\mid \begin{array}{c}\text { MS } \\
\text { CONCENTRATION } \\
\text { OG/KG }\end{array}$ & \begin{tabular}{c|} 
MS \\
REC \\
RE
\end{tabular} & & $\begin{array}{l}\text { MITS } \\
\text { REC }\end{array}$ \\
\hline \multicolumn{7}{|c|}{ 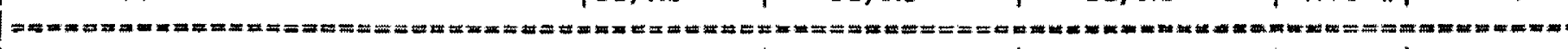 } \\
\hline Arochlor -1016 & 170 & 0 & 206 & 122 & 160 & -140 \\
\hline Arochlor -1260 & 170 & 0 & 0 & I & 160 & -140 \\
\hline
\end{tabular}

\begin{tabular}{|c|c|c|c|c|c|c|c|}
\hline COMPOUND & $\left\{\begin{array}{c}\text { SPIKE } \\
\text { ADDED } \\
\text { UG/KG }\end{array}\right.$ & $\begin{array}{c}\text { MSD } \\
\text { CONCENTRATION } \\
\text { UG/KG }\end{array}$ & $\begin{array}{l}\text { MSD } \\
\text { REC \# }\end{array}$ & RPD \# & \multicolumn{3}{|c|}{ QC LIMITS } \\
\hline \multicolumn{8}{|c|}{ 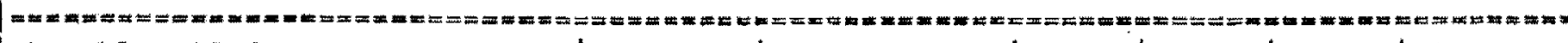 } \\
\hline Arochlor-1016 & 170. & 208 & 122 & 0 & NA & 160 & -140 \\
\hline Arochlor -1260 & 170 & 0 & $I$ & 0 & NA & 160 & -140 \\
\hline
\end{tabular}

* Column to be used to flag recovery and RPD values with an asterisk

* Values outside of QC limita

RPD: $\quad 0$ out of 2 outside limits Spike Recovery: 0 out of 4 outside limits COMMENTS:

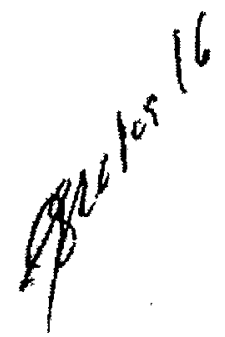


SOIL PESTICIDE MATRTX SPIKE RECOVERY

Lab Name: Lionville Labs. Inc.

Case No.: BECHTEL NEVADA V2684

MATRIX Spike - Sample No.: PBLKJALE0462-MB1
Contract: $0052-0.1-01$

RFW Lot No.: $0605 \mathrm{~L} 133$

\begin{tabular}{|c|c|c|c|c|c|c|}
\hline COMPOUND & $\begin{array}{l}\text { SPIKE } \\
\text { ADDED } \\
\text { UG } / K G\end{array}$ & $\begin{array}{c}\text { SAMPLE } \\
\text { CONCBNTRATION } \\
\text { UG/KG }\end{array}$ & $\begin{array}{l}\text { MS } \\
\text { CONCENTRATION } \\
\text { UG/KG }\end{array}$ & $\begin{array}{l}\text { MS } \\
\text { REC \# }\end{array}$ & & $\begin{array}{l}\text { C } \\
\text { RITS }\end{array}$ \\
\hline \multicolumn{7}{|c|}{ 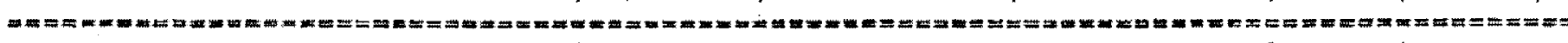 } \\
\hline Arochlor-1016 & 167 & 0 & 175 & 105 & 160 & -140 \\
\hline Arochlor -1260 & 167 & 0 & 180 & 108 & 160 & -140 \\
\hline
\end{tabular}

\# Column to be used to flag recovery value with an asterigk

* Values outside of QC limits

Spike Recovery: $\quad 0$ out of 2 outside limits

COMMENTS:

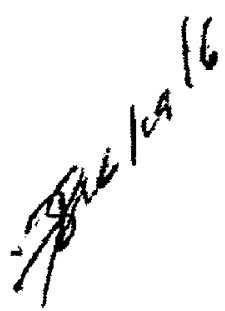

Leve 1: (Low/med) LOW 
$3 \mathrm{E}$

WATER PESTICIDE MATRIX SPIKE/MATRIX SPIKE DUPLICATB RBCOVERY

Lab Name: Lionville Labs. Inc.

Case NO.: BECHTEL NEVADA Y2684
Contract: $\quad 0052-01-01$

RFW LOt NO.: $0605 \mathrm{~L} 133$
MATRIX Spike - Sample No.: PBLKIPLEO443-MBI
Level; (low/med) Low

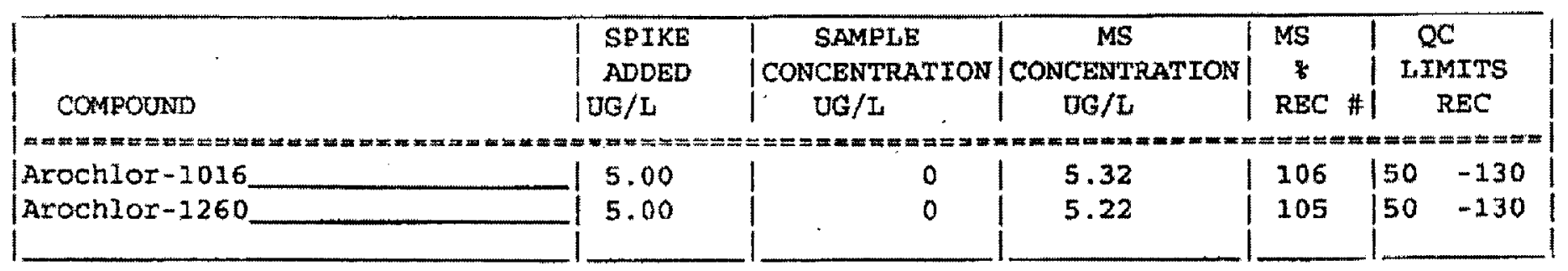

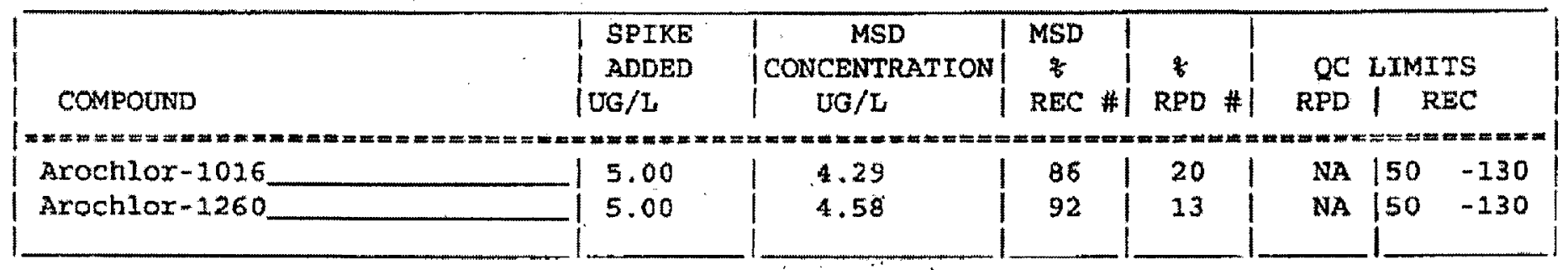

\# Colun to be used to flag recovery and RpD values with an asterisk

* Values outside of QC limits

RPD: 0 out of 2 outside limits

spike Recovery: 0 out of 4 outside inits

COMENTS:

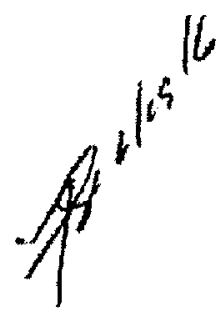


$4 D$

METHOD BLANK SUMMARY

Lab Name: Lionville Labs. Inc.

Contract: $\quad 60052-001-001-0001-00$

Case No.: BECHTET NEVADA V2684

Lab Sample ID: 06LE0462-MBI

Lab File ID: BLKO8330.01

Matrix:(Soil/water) SOIL

Level : (low/med) Low

Date Extracted: $\underline{06 / 06 / 06}$

Extraction: (SepF/Cont/Sonc) $\star * \star * *$

Dace Analyzed (1): $06 / 13 / 06$

Time Analyzed (1):

Instrument ID (1): 13

GC Column ID (1): RTX-CLP

THIS METHOD BLANK APPLIES TO THE FOLLOWING SAMPLES, MS, AND MSD:

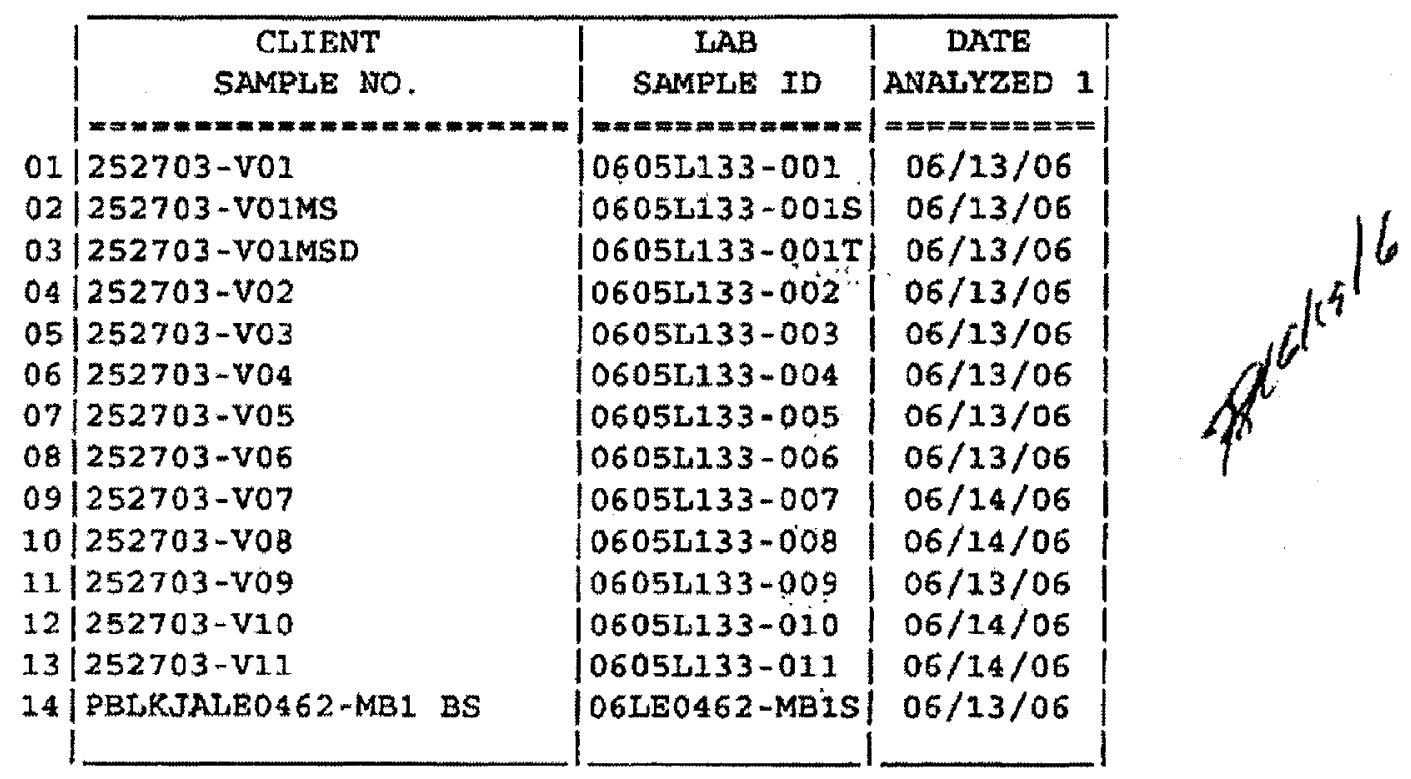

COMMENTS : 
Lab Name: Lionvilile Habs. Inc.

Case No.: BECHTEL NEVADA Y2684

Lab Sample ID: 06LR0443-MBI

Matrix: (Soi1/Water) WATER

Date Extracted: 05/29/06

Date Analyzed (1): $06 / 04 / 06$

Instrument ID (1):
Contract: $\quad 60052-001-001-0001-00$

Lab File ID: BLKOOPPB.02

Level:(10w/med) LOW

Extraction:(SepF/Cont/Sonc) CONT

Time Analyzed (1):

GC column ID (1): RTX-CLP2

THIS METHOD BLANK APPLIES TO THE FOLLOWING SAMPLES, MS, AND MSD:

COMMENTS :

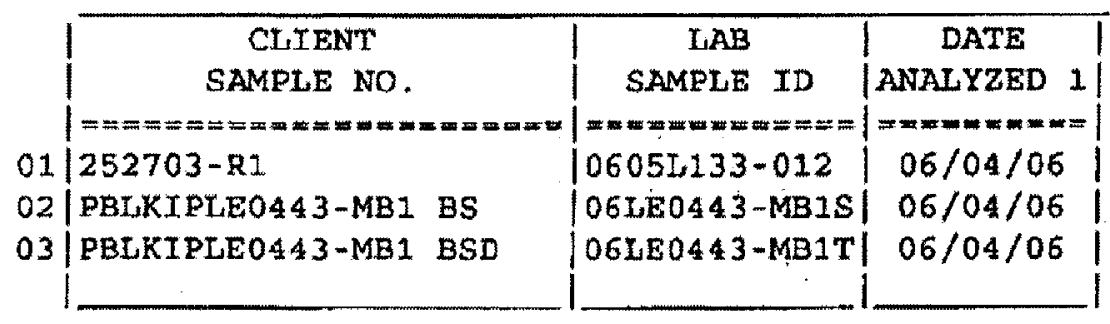

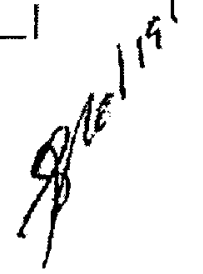




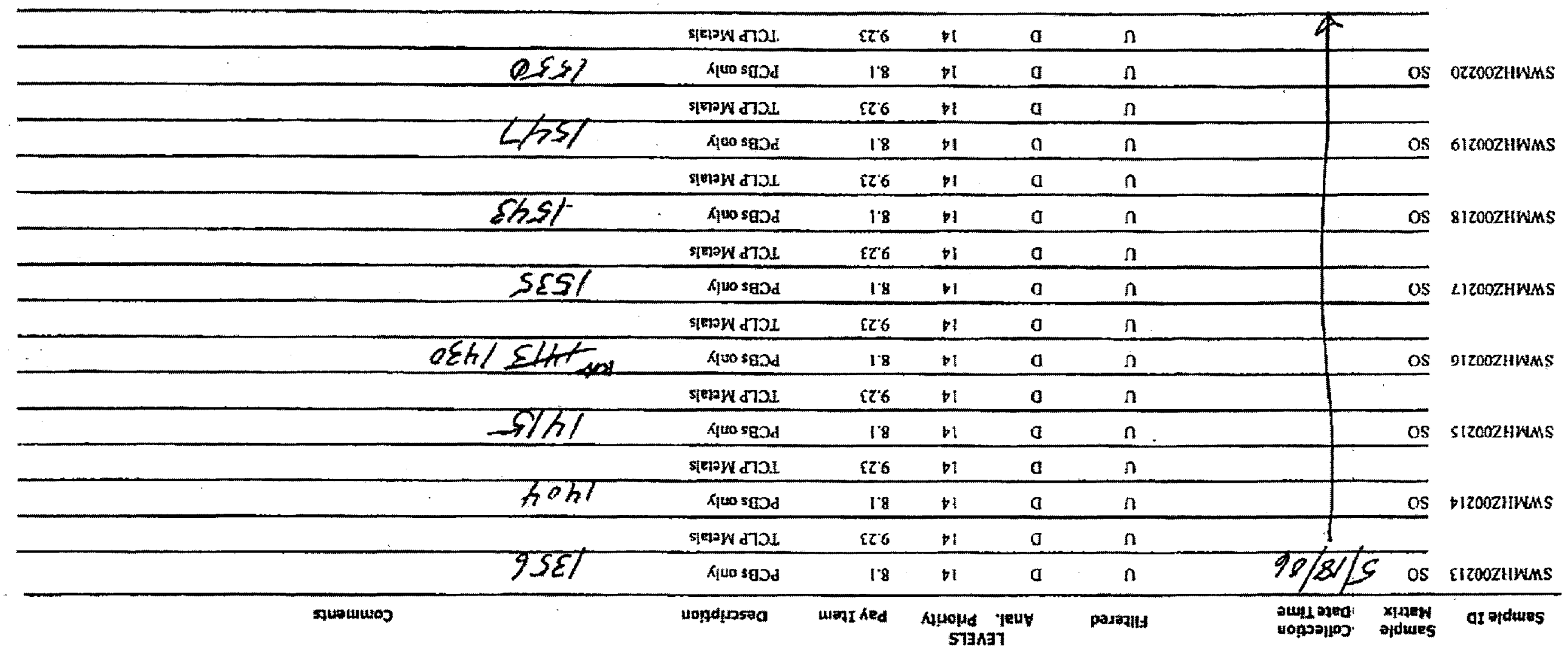

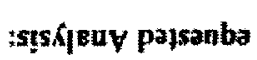

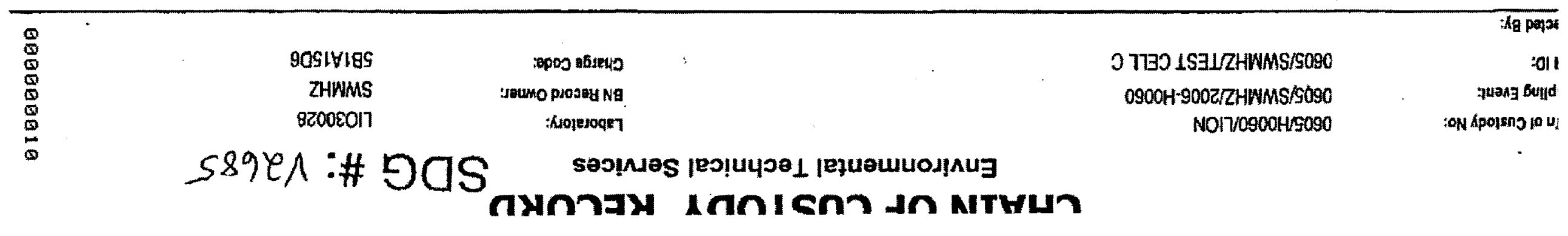




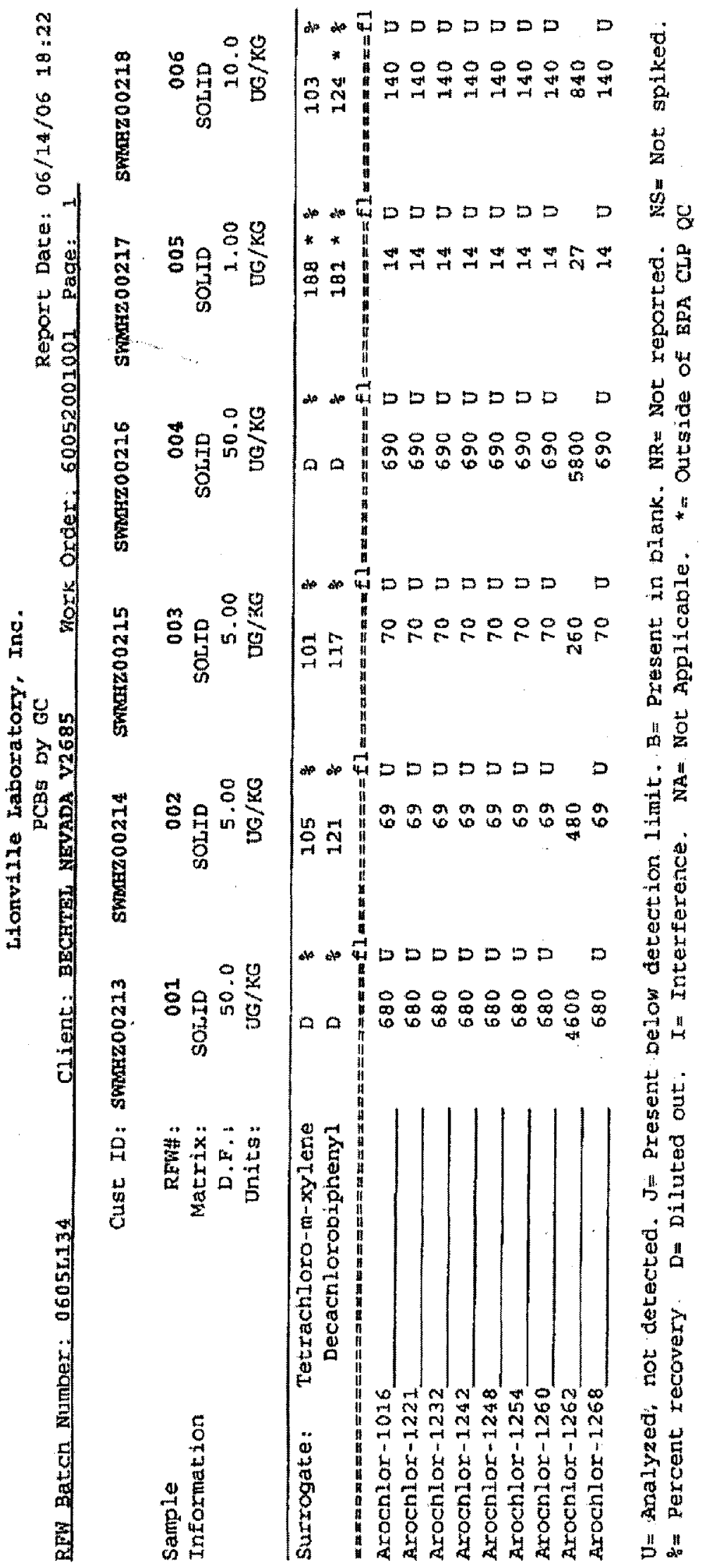




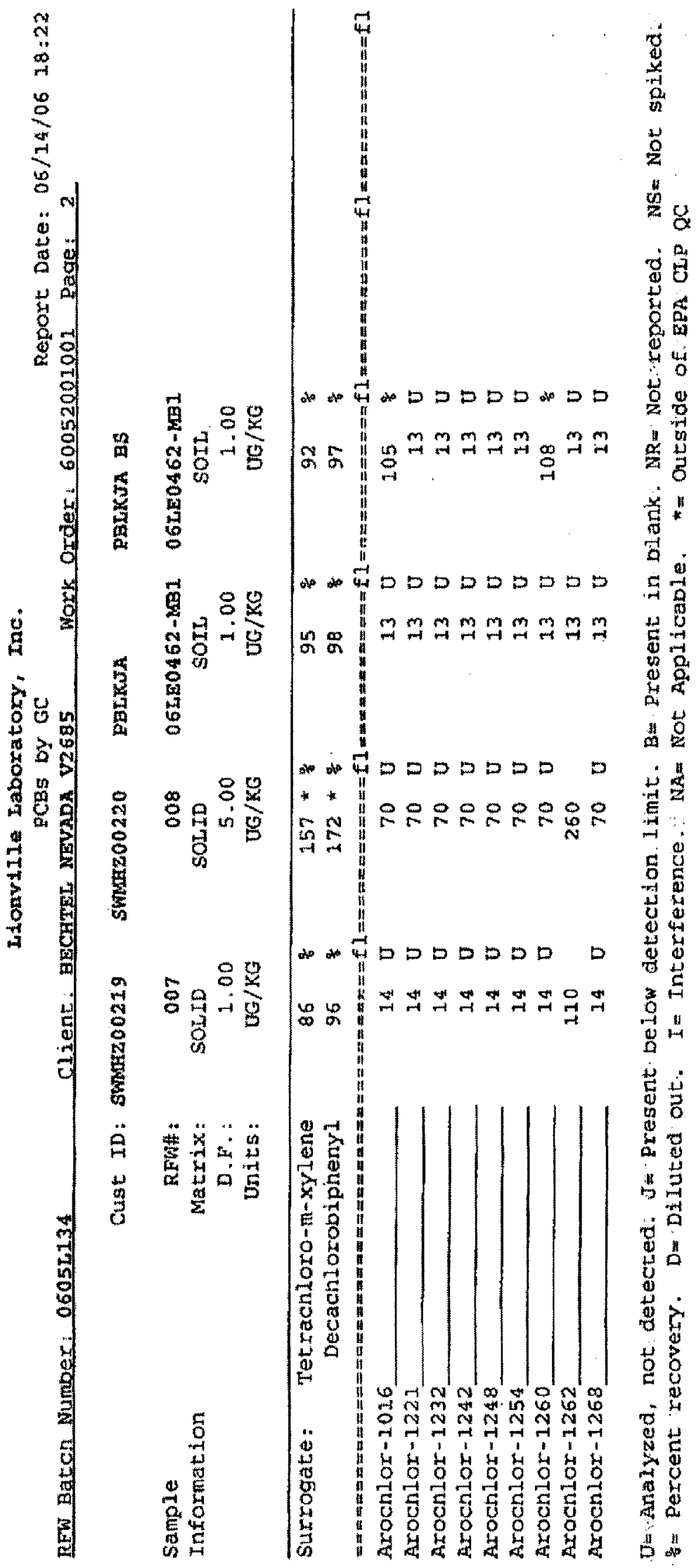


CIFNT: GRCHTBI WEVADA V264S

JORK ORDER: 50052-002*001-0002*00

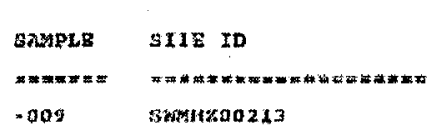

$-220 \quad$ SHMF:2002:4

$.011 \quad 561200215$
XKA:

Silvox IClo taudiate

Areense Iezp toachati

Haxium roue tominte

Cadraium, ICLP Laxchace

cinromium, ICtin Latichnes:

Mereury 1Che toachata

I enad, ICLP treachate

selenius robe remahan

SIIvex, ICIP Leakhace

Areanic ICle loachata

Batiun jete leschet

cadaium, terp toachato

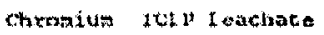

Sexcury. ICL I wachate

tead, TCip weachnte

solentum, 1Cl, Itomena:

situas yted fochata

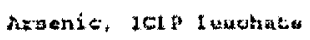

Saxiua, ICI Leachate

Cadnium TCLF Leachate

Chromina, ICL Leactatia

Morcury, ICIP umelhate

Iand ICLP trachute

soluniur, :C: seachate

SElver ICt Loshute

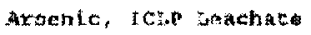

Iarifm ICLF loachate

Catrium I CLP leachate

Chremiun tot: teachato

Hextury, Iclp Leduchate

lead, TCle teachat

stienium, rece tonehate
LVL LOI $=0 \operatorname{cose} 134$

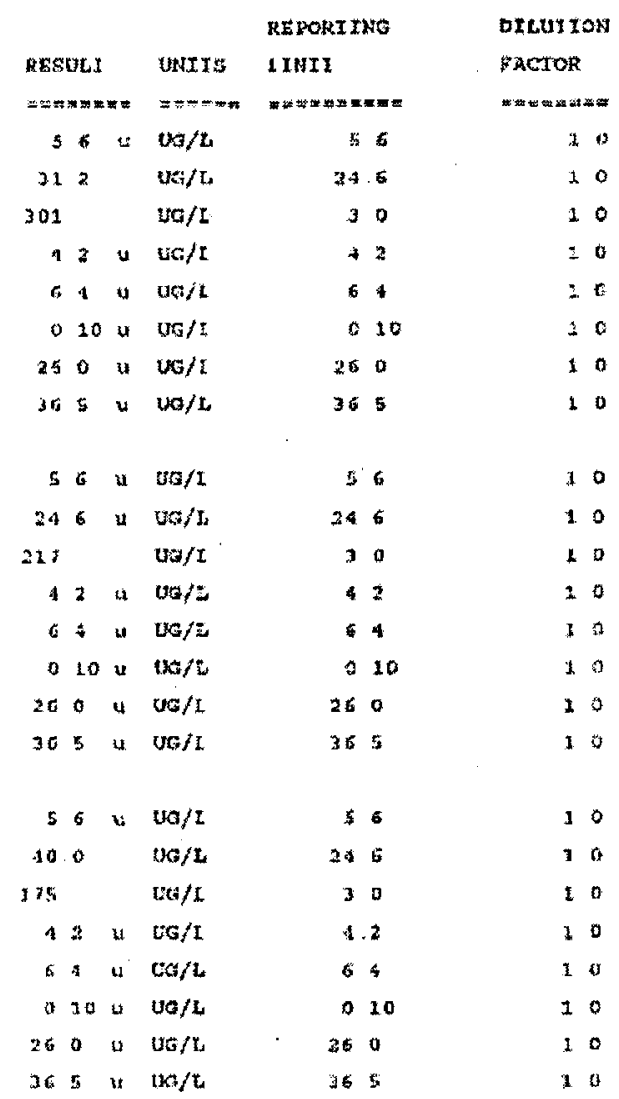

\begin{tabular}{|c|c|c|c|c|c|c|}
\hline 5 & 5 & $u$ & $W G / I$ & & 6 & 10 \\
\hline 24 & 6 & u & UG / I & 24 & 6 & 10 \\
\hline 251 & & & $0 \times / 1$ & 3 & 5 & 10 \\
\hline A. & 2 & $u$ & $\mathrm{DG}_{\mathrm{N}} / \mathrm{T}$ & 4 & 2 & 10 \\
\hline & 1 & $u$ & $t$ & 6 & 4 & 10 \\
\hline 0 & 10 & $u$ & $\pi 0 / t$ & 0 & 10 & 16 \\
\hline 26 & 0 & s & We/t. & 26 & 0 & 10 \\
\hline 36 & 5 & ix & $u \omega_{1} / L$ & 36 & 5 & $\Rightarrow 0$ \\
\hline
\end{tabular}




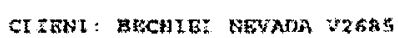

FORK ORDER: 60052-001-001-0001-00

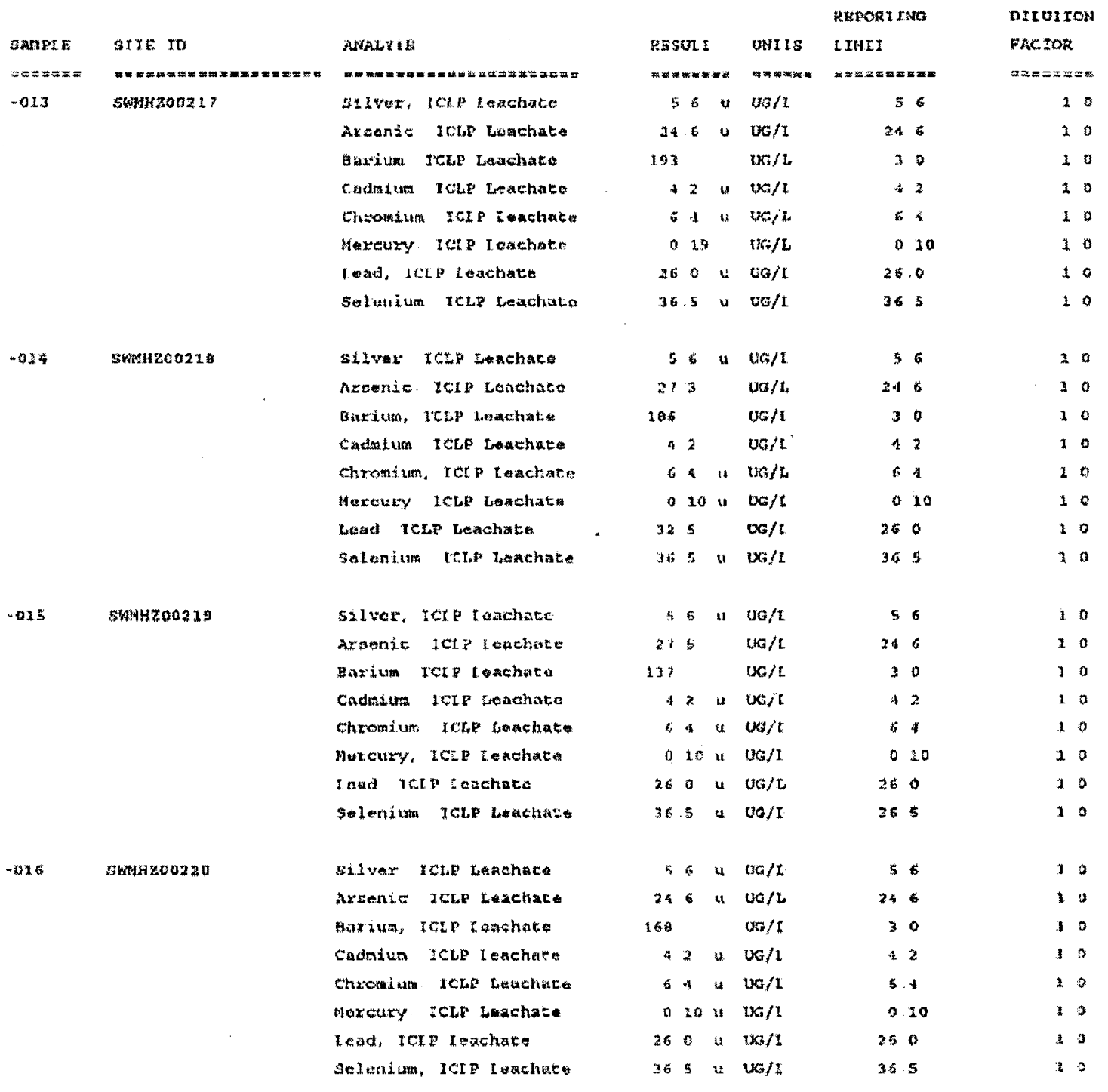


TNORGPNICO UELHOO LLASK DAIA SUKMARY PAGE OG/OE/OG

CLIENI: EECHXEL MENADN 72685

FORK ORDERL: 600\$2-002 -002-0001-00

\begin{tabular}{|c|c|}
\hline SAnat & SIE 10 \\
\hline 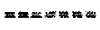 & 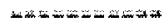 \\
\hline BLNNIX1. & $0640349-451$ \\
\hline
\end{tabular}

ELANBC O5LO349-612

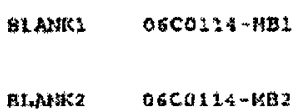

\section{TNALYIE}

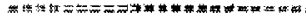

Silvar terp I cachatin

Axomite, IC10 L tachate

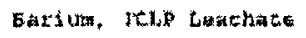

Eachive IC! $P$ S enchatem

chrowivin, rere isechato

IEà, PCI Lasichato

Selenitum, retep tomeraco

ailvox TCLP Lesehaco

Arcanic Iots Loarhace

ba:Lum tct8 lewehate

Cad tera louchato

Chromiun, ICL Lexchata

Lead. $7 \mathrm{CL}^{2}$ Letathate

salenium, ICI ioncirate

Mareuxy lotal

Hercury tci toachato
IVI IOt 2 ; 050Stata

\begin{tabular}{|c|c|c|c|c|c|}
\hline & & & & RBPORTING & DrtuIrow \\
\hline Rast & UE I & & UNIIS & I CHII & PACIOR \\
\hline 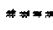 & $x=m$ & & 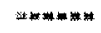 & 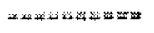 & 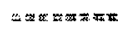 \\
\hline 5 & $\pi$ & $\mathbf{u}$ & $U G / 1$ & 56 & $=0$ \\
\hline 24 & 6 & $\mathbf{u}$ & veit & 24 & $2 \mathrm{c}$ \\
\hline 3 & D & $\mathbf{u}$ & $v \in / 1$ & 30 & 10 \\
\hline 4 & 2 & $"$ & vo/I & +2 & 10 \\
\hline 6 & 4 & $\mathbf{u}$ & $\cos t$ & 64 & 20 \\
\hline 26 & 0 & $\mathbf{1}$ & $\mathrm{ccc} / \mathrm{t}$ & 260 & 10 \\
\hline 36 & 5 & $\mathbf{u}$ & $\omega G / L$ & 365 & 10 \\
\hline 5 & 6 & 4 & UG $/ L$ & 56 & 20 \\
\hline $2 *$ & 6 & แ & $0, / L$ & 246 & 10 \\
\hline 3 & 0 & " & Wots & 30 & 10 \\
\hline 4 & $z$ & it & uG/L & 42 & 10 \\
\hline 6 & 4 & !! & $\mathrm{UG} / \mathrm{t}$ & $=1$ & 10 \\
\hline 26 & 0 & $\Psi$ & $U G / l$ & 26.0 & 1. a \\
\hline 36 & 5 & $\mathbf{u}$ & $00 / \mathrm{L}$ & 365 & 10 \\
\hline
\end{tabular}

a $10400 / 1$

o 10

10

0 10 th $59 / 2$

020

10 
dionvill Laberatosy ine

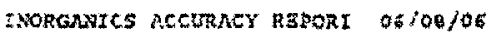

CLIMINZ: GRCHIBI NEVARA V2645

Wokk ORDER: 60052-001-001-0001-00

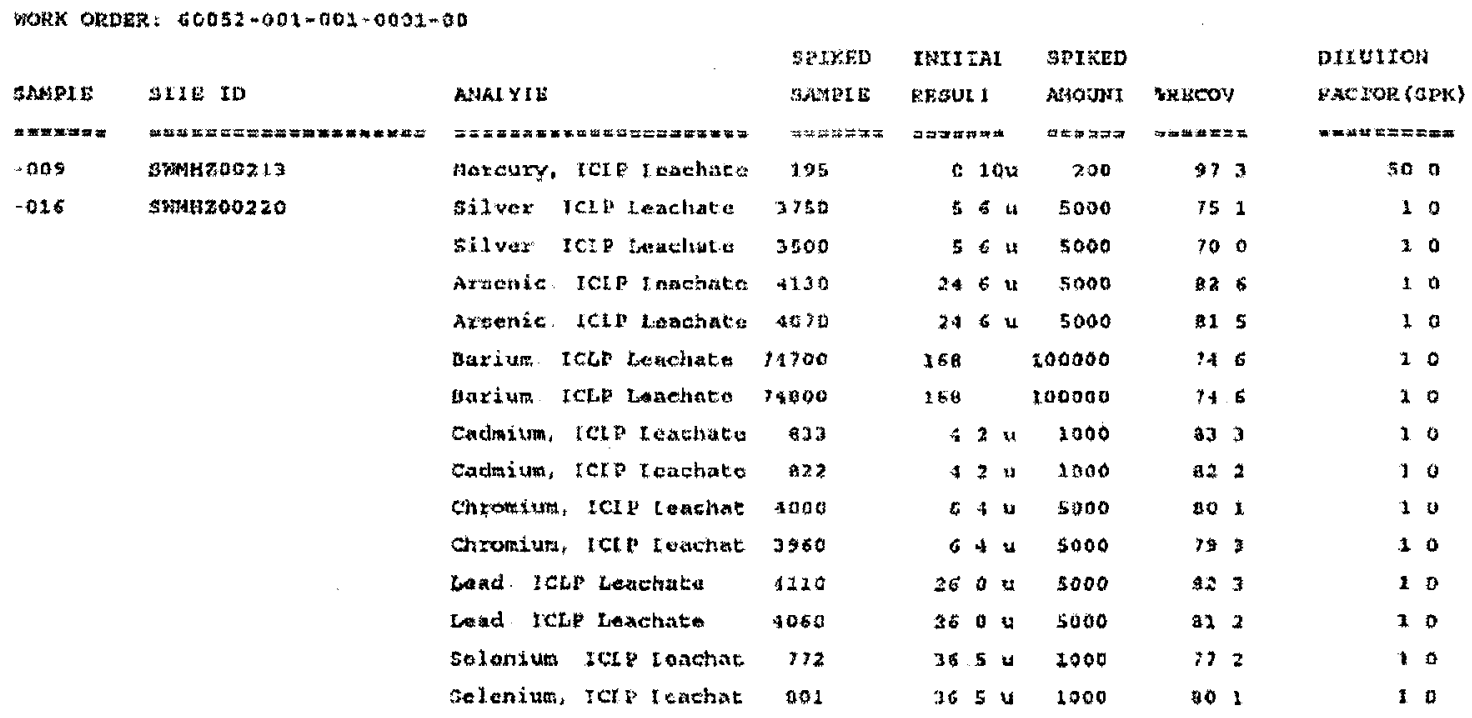

LVL LOT $11=06056234$ 
IHORGNUTCS DUT:TCAT: SPIKB REPCRT OG/OQ/06

Cl IBWI : BEWHER HEYADA V2695

AORTK ORDER; $60552-001$-OO1-600R-f0

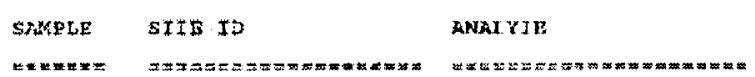

$-016$

S4⿻上丨冖

I.vax ICLP Leachaco
LVI L.OT : 10605IX34

SPLKB:4 SRIKEH2

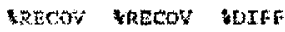

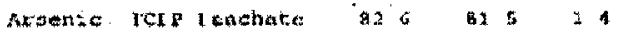

Bariun. ICLP Leachate 748 it 5 obu

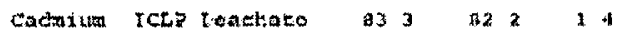

chrotain, ECEl teachate $B 01$ to 099

I ead ICI tomehate

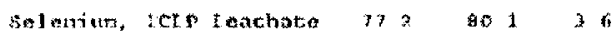


Lonvilde Inbaratory wat

THORGMNYCS LAEORATORY CON1ROI GIANDAROS REPORI 06/0B/196

\begin{tabular}{|c|c|c|}
\hline SAMPLE & $5 x+10$ & Bistar. \\
\hline 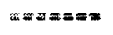 & 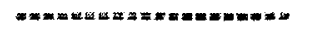 & 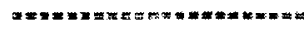 \\
\hline \multirow[t]{7}{*}{$\operatorname{tcs} 1$} & $0550369+102$ & stuser, 103 \\
\hline & & Axeanie les \\
\hline & & Exrium tes \\
\hline & & cadplut tes \\
\hline & & Chromilum ICs \\
\hline & & Load Les \\
\hline & & Solenium tes \\
\hline 681 & $06 C \$ 114-401$ & Harrusy LCs \\
\hline
\end{tabular}

IV: toI

\begin{tabular}{|c|c|c|c|}
\hline sรTiko & 3RTKEO & & \\
\hline SARELE & Aroun1 & UNIIS & ERECOV \\
\hline 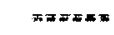 & $\|=x=x=2$ & 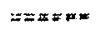 & 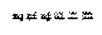 \\
\hline 490 & 590 & $U a / 5$ & 200 \\
\hline 10100 & 10000 & $v_{G / I}$ & 2008 \\
\hline 1220 & 5000 & $v \in / \mathbf{k}$ & 9a 4 \\
\hline $24: 4$ & 250 & $t \in d t$ & 975 \\
\hline 156 & 500 & $\mathrm{te} / \mathrm{t}$ & s71 \\
\hline 2360 & 2500 & ve $/ \mathrm{L}$ & 943 \\
\hline $16 \div 00$ & 10000 & tes $/ 1$ & 200 \\
\hline
\end{tabular}

5150 bo/t $202 B$ 


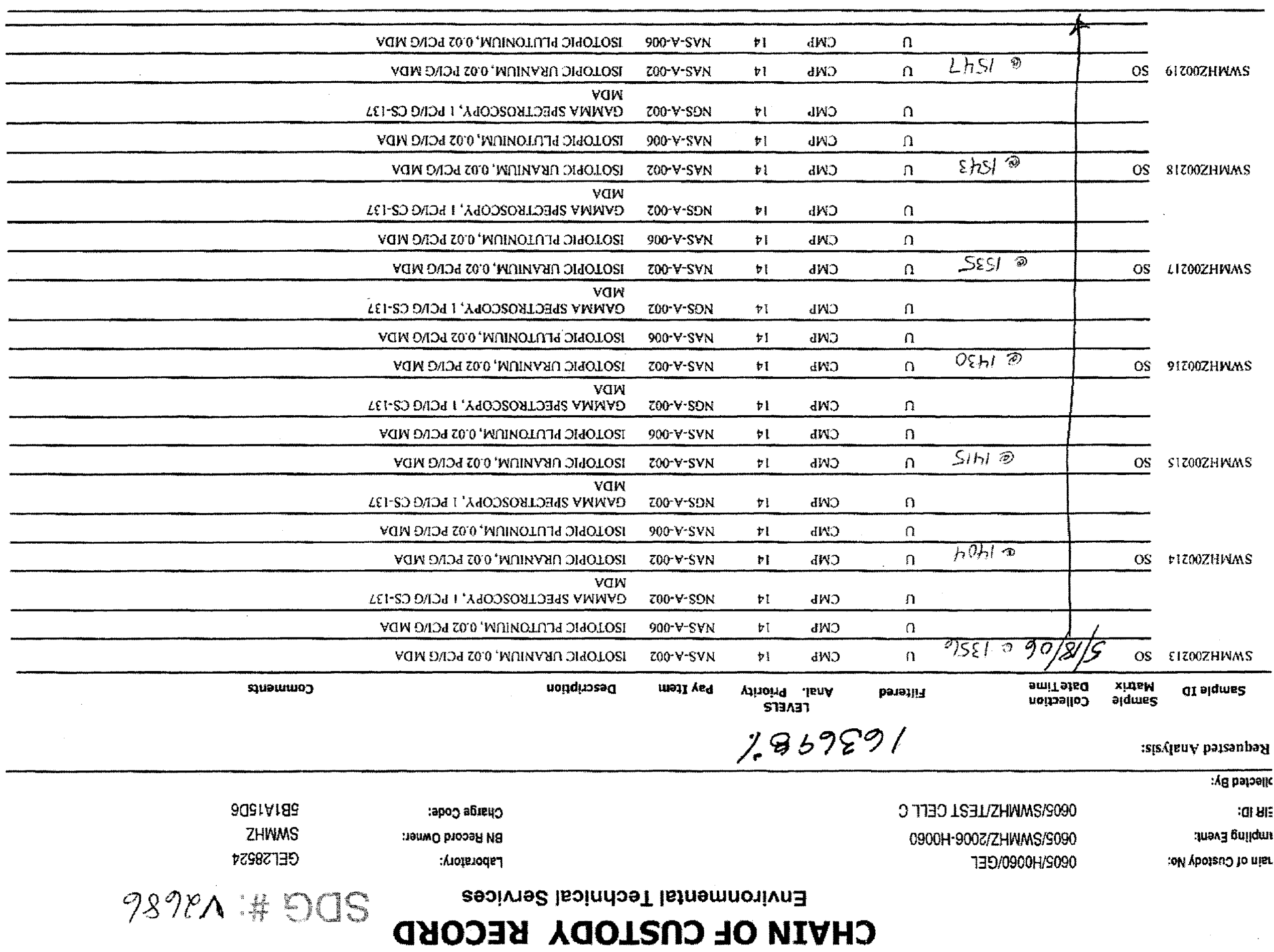


Requested Analysis:

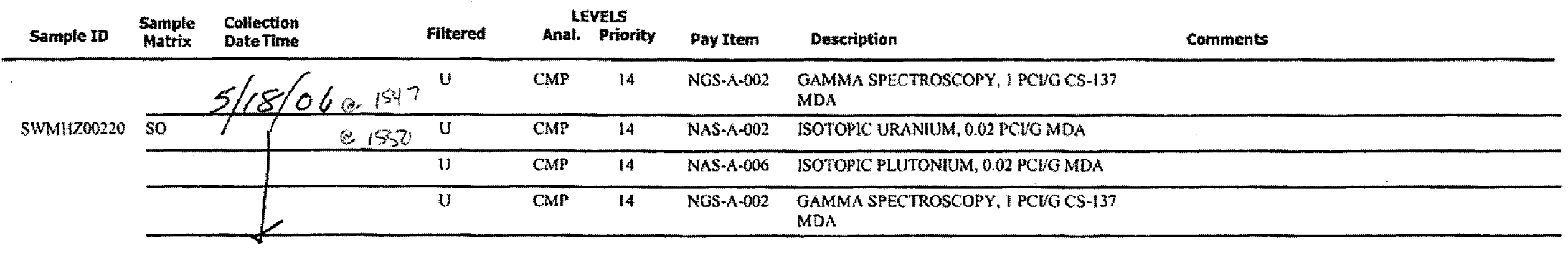




\title{
GENERAL ENGINEERING LABORATORIES, LLC
}

2040 Savage Road Charleston SC 29407 - (843) 556 -8171 - www gel.com

\section{Certificate of Analysis}

\author{
Company: Bechiel Nevida \\ Address: Warehouse 160, NTS 270 \\ Mercury, Nevada 89023 \\ Contact: Mr. Theodore Rodding \\ Project: Environmental Rad Analysis
}

Report Date: June 22, 2006

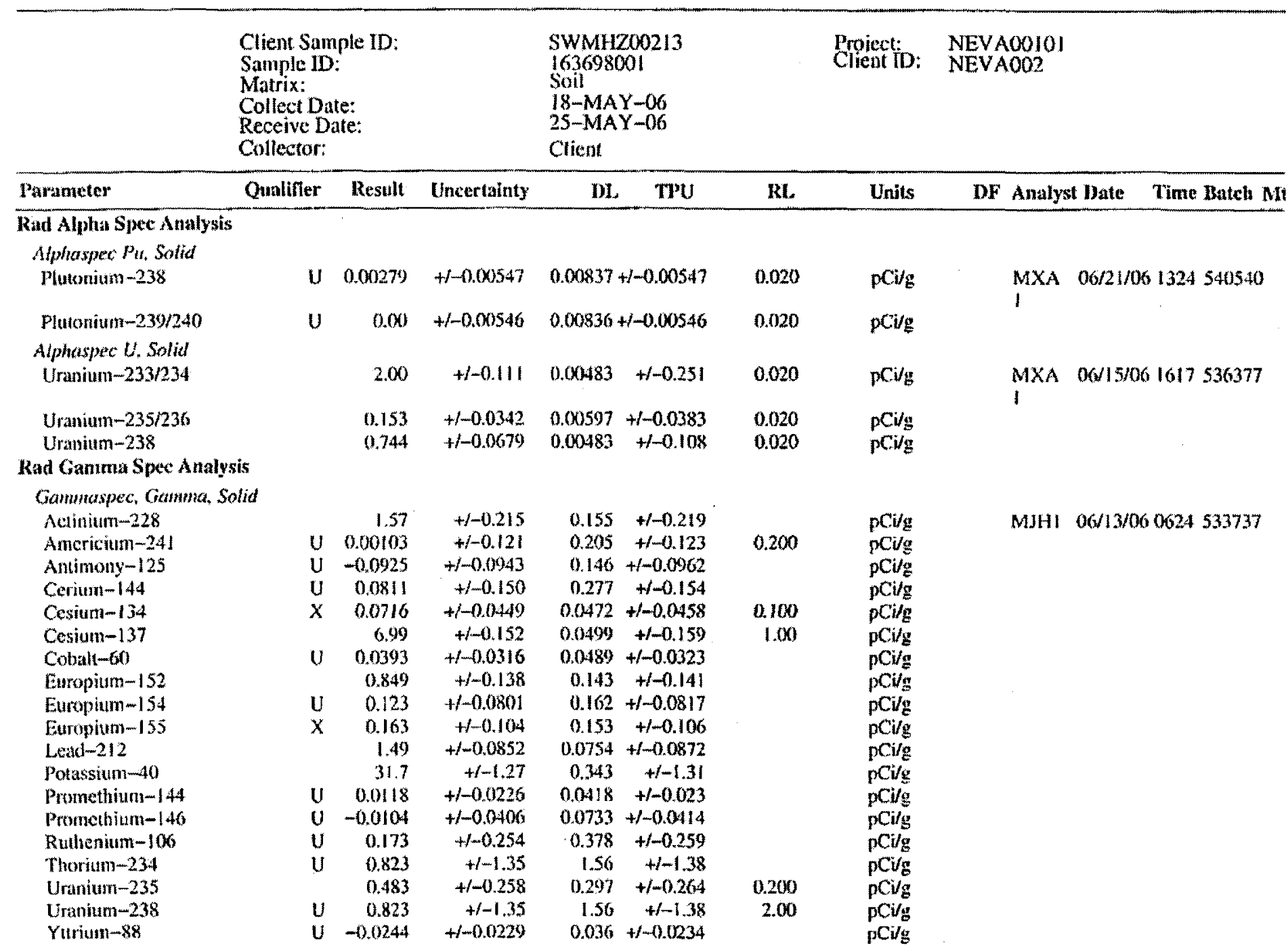

The following Prep Methods were performed

\begin{tabular}{llllll}
\hline Method & Description & Analyst & Date & Time & Prep Batch \\
\hline Ash Soil Prep & Ash Soil Prep, GL-RAD-A-0218 & AXP2 & $05 / 30106$ & 1519 & 533869 \\
Dry Soil Prep & Dry Soil Prep GL-RAD-A-021 & LXM2 & $05 / 28 / 06$ & 1016 & 533732
\end{tabular}




\section{GENERAL ENGINEERING LABORATORIES, LLC \\ 2040 Savage Road Charleston SC 29407 - (843) 556-8171 - www.gel.com}

\section{Certificate of Analysis}

Company: Becthel Nevada

Address: Warchouse 160, NTS 270

$\begin{array}{ll} & \text { Mercury, Nevadi } 89023 \\ \text { Contact: } & \text { Mr. Thendore Reding } \\ \text { Project: } & \text { Environmental Rud Analysis }\end{array}$

Repont Date: June 22, 2006

Client Sample ID: SWMHZ00213 Proiect: NEVAO0101

Sample ID: 163698001 Client ID: NEVAOO2

\begin{tabular}{llllllll}
\hline Parameter Qualifier Result Uncertainty & DL & TPU & RL. & Units DF Analyst Date Time Batch M!
\end{tabular}

The following Analylical Methods were performed

\begin{tabular}{ll}
\hline Method & Description \\
\hline 1 & DOE EML HASL-300, PI- $11-$ RC Modificd \\
2 & DOE EML HASL-300, PU-11-RC Modified \\
3 & DOE EML HASL-300, U-02-RC Modified \\
4 & EML HASL 300, $4.5,2.3$
\end{tabular}

\begin{tabular}{llcc} 
Surrogater Tracer recovery & Test & Recovery\% & Acceptable Limits \\
\hline Plutonium-242 & Alphaspec Pu, Solid & 81 & $(15 \%-125 \%)$ \\
Uraniam-232 & Alphaspec U, Solid & 74 & $(25 \%-125 \%)$
\end{tabular}

Notes:

The Qualitiers in this report are defined as tollows :

* A quality control analyte recovery is outside of specified acceptance criteria

$<$ Result is less than value reported

$>$ Result is greater than value reported

A The TIC is as suspected aldol-condensation product

B Target analyte was detected in the associated blank

$\mathrm{BD}$ Results are either below the MDC or tracer recovery is low

C. Analyte ins been confirmed by GC/MS analysis

D Results are reported from a diluted afiquot of the sample

H Analytical holding time was exceeded

J Value is estimated

N/A Spike recovery limits do not apply. Sample concentration exceds spike concentration by $4 X$ or more

$R$ Sample results are rejected

U Analyte was analyzed for, but not detected above the MDL, MDA, or LOD.

UI Gamma Spectroscopy - Uncertain identification

$X$ Consult Case Narrative, Data Summary package, or Project Manager concerning this qualifier

$Y$ QC Samples were not spiked with this compound

$\wedge$ RPD of sample and duplicate cvaluated using $+/-\mathrm{RL}$. Concentrations are $<5 \mathrm{X}$ the RL.

h Preparation or preservation holding time was exceeded

The above sample is reported on a dry weight basis. 


\title{
GENERAL ENGINEERING LABORATORIES, LLC \\ 2040 Savage Road Charleston SC 29407 - (843) 556-8171 - www.gel.com
}

\section{Certificate of Analysis}

\author{
Company: Bechiel Nevada \\ Address: Warchouse 160, NTS 270

$\begin{array}{ll} & \text { Mercury, Nevado } 89023 \\ \text { Contact: } & \text { Mr. Theodore Reduing } \\ \text { Project: } & \text { Environmental Rad Analysis }\end{array}$ \\ Client Sample ID: \\ Sample ID: \\ Matrix: \\ Collect Date: \\ Receive Date: \\ Collector:

SWMHZ00214
163698002
Soil
$18-\mathrm{MAY}-06$
$25-\mathrm{MAY}-06$
Client

Report Date: June 22, 2006

Proiect: NEVAOOIOI

Client ID: NEVAOO2

Qualifier Result Uncertainty

DL. TPU

RL.

Units

DF Amalyst Date Time Batch M

\begin{tabular}{|c|c|c|c|c|c|c|c|c|c|}
\hline \multicolumn{10}{|c|}{ Rud Alpha Spec Analysis } \\
\hline \multicolumn{10}{|l|}{ Alphaspect Pu, Soltd } \\
\hline Putonitun-238 & $\mathrm{U}$ & 0.00164 & $+1-0.00727$ & 0.0209 & $+1-0.00727$ & 0.020 & $\mathrm{pCi} / \mathrm{g}$ & $M \times A$ & $06 / 21 / 061324540540$ \\
\hline Plutonium $-239 / 240$ & $\mathrm{U}$ & 0.00662 & $+1-0.00917$ & 0.00993 & $+1-0.0092$ & 0.020 & $\mathrm{pCi} / \mathrm{g}$ & & \\
\hline \multicolumn{10}{|l|}{ Alphaspece U, Solid } \\
\hline Granium-2337234 & & 1.39 & $+1-0.0962$ & 0.0132 & $+/-0.184$ & 0.020 & $\mathrm{pCi} / \mathrm{g}$ & $M \times A$ & $06 / 157061617536377$ \\
\hline Unanium-235/236 & & 0.0962 & $+1-0.0281$ & 0.00641 & $+1-0.0301$ & 0.020 & $\mathrm{pCi} / g$ & & \\
\hline Uranitun-238 & & 0.730 & $+1-0.070$ & 0.0166 & $+1-0.108$ & 0.020 & $\mathrm{pCig}$ & & \\
\hline \multicolumn{10}{|c|}{ Rad Gamma Spec Analysis } \\
\hline \multicolumn{10}{|c|}{ Ganmaspec, Gammma, Solid } \\
\hline Actiniun: $-2 \geq 8$ & & 1.42 & $+1-0.233$ & 0.180 & $+1-0.237$ & & $\mathrm{pCig}$ & MJHI & $06 / 13 / 060625533737$ \\
\hline Americium-241 & $\mathrm{U}$ & 0.0178 & $+1-0.148$ & 0.255 & $+1-0.152$ & 0.200 & $\mathrm{pCV} / \mathrm{g}$ & & \\
\hline Antimony-125 & $U$ & 0.0453 & +10.0604 & 0.114 & $+1-0.0616$ & & $\mathrm{PCV}$ & & \\
\hline Ccrium-144 & $\mathbf{u}$ & 0.028 & +10.147 & $0.24 !$ & $+1-0.150$ & & $\mathrm{pCi} / \mathrm{g}$ & & \\
\hline Cesium-134 & $\mathrm{x}$ & 0.0689 & $+7-0.0446$ & 0.0546 & $+1-0.0455$ & 0.100 & $\mathrm{pCVg}$ & & \\
\hline Cesium-137 & & 0.246 & $+1-0.0476$ & 0.0462 & $+1-0.0486$ & 1.00 & $\mathrm{pCi} / \mathrm{g}$ & & \\
\hline Cobali-60 & $\mathbf{U}$ & 0.00265 & $+1-0.0284$ & 0.0514 & $+/-0.029$ & & $\mathrm{pCi} / \mathrm{g}$ & & \\
\hline Europium-152 & & 0.644 & $+1-0.115$ & 0.115 & $+/-0.117$ & & $\mathrm{pCi} / \mathrm{g}$ & & \\
\hline Europium-154 & u & -0.0163 & +10.113 & 0.171 & $+1-0.116$ & & $\mathrm{pCi} / \mathrm{g}$ & & \\
\hline Europium-155 & $\mathrm{U}$ & 0.0666 & $+1-0.0977$ & 0.137 & $+1 / 0.0997$ & & $\mathrm{pCl} / \mathrm{g}$ & & \\
\hline Lead-212 & & 1.65 & $+1 / 0.0814$ & 0.0662 & $+/-0.0835$ & & $\mathrm{pCig}$ & & \\
\hline Potassium -40 & & 34.9 & $+/-1.44$ & 0.393 & $+1-1.48$ & & $\mathrm{pCV} / \mathrm{g}$ & & \\
\hline Promethium-144 & $u$ & -0.00487 & $+1-0.0242$ & 0.0421 & $+1-0.0247$ & & $\mathrm{pCi} / \mathrm{g}$ & & \\
\hline Promethium-146 & $\mathrm{U}$ & 0.00928 & $+/-0.0306$ & 0.0561 & $+/-0.0312$ & & $\mathrm{pCi} g$ & & \\
\hline Ruthenium-106 & $U$ & -0.0831 & $+/-0.222$ & 0.385 & $+t-0.226$ & & $\mathrm{pCV} / \mathrm{g}$ & & \\
\hline Thorium-234 & $x$ & 1.94 & $+1-1.89$ & 1.92 & $+1-1.93$ & & $\mathrm{pCV} / \mathrm{g}$ & & \\
\hline Uranium-235 & $\mathrm{u}$ & 0.030 & $+1-0.142$ & 0.258 & $+1-0.145$ & 0.200 & $\mathrm{pCi}_{\mathrm{g}}$ & & \\
\hline Uraulum-238 & $x$ & 1.94 & $+1-1.89$ & 1.92 & $+J-1.93$ & 2,00 & $\mathrm{pCi} / \mathrm{g}$ & & \\
\hline Yttrium-88 & u & 0.00884 & $+1-0.0269$ & 0.0526 & $+1-0.0275$ & & $\mathrm{pCv} / \mathrm{g}$ & & \\
\hline
\end{tabular}

The following l'rep Methods were performed

\begin{tabular}{llllll}
\hline Method & Deseription & Alsalyst & Date & Time & Prep latch \\
\hline Ash Soil Prep & Asli Soil Prep, GL-RAD A-021B & AXP2 & $05 / 30 / 06$ & 1519 & 533869 \\
Dry Soil Prep & Dry Soil Prep GL-RAD -A-021 & LXM2 & $05 / 28 / 06$ & 1016 & 533732
\end{tabular}




\section{GENERAL ENGINEERING LABORATORIES, LLC \\ 2040 Savage Road Charleston SC 29407 - (843) 556-8171 - www.gel.com}

\section{Certificate of Analysis}

Company: Bechel Nevada

Address: Warchouse 160 , NTS 270

$\begin{array}{ll} & \text { Mercury, Nevada } 89023 \\ \text { Contact: } & \text { Mr. Theodore Redding } \\ \text { Project: } & \text { Environmental Rad Analysis }\end{array}$

Report Date: June 22, 2006

Client Sarmple ID: Sample 1D:

SWMHZ00214
163698002
Proiect: Client ID:
NEVA00101

NEVAOO2

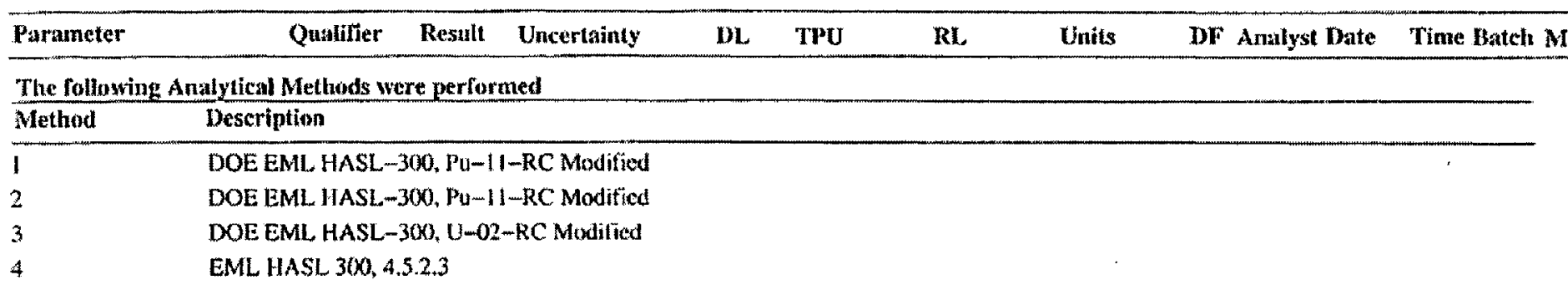

\begin{tabular}{llcc} 
Surrogatefracer recovery & Test & lecovery\% & Acceptable Limits \\
\hline Plutonium-242 & Alphaspec Pu. Solitl & 71 & $(15 \%-125 \%)$ \\
Uranium-232 & Alptaspec U, Solid & 67 & $(25 \%-125 \%)$
\end{tabular}

Notes:

The Qualifiers in this report are defined as follows :

* A quality control analyte recovery is outside of specified acceptance criteria

$<$ Result is less than value reported

$>$ Result is greater than value reported

A The TIC is a suspected aldol-condensation product

B Target analyte was detected in the associated blank

BD Restults are either below the MDC or tracer recovery is low

C Analyte has been confirmed by GC/MS analysis

D Results are reported from a difutcd aliquot of the sample

H Analytical holding time was exceeded

$\mathrm{J}$ Value is estimated

N/A Spike recovery limits do not apply. Sample concentration exceeds spike concentration by $4 X$ or more

$\mathrm{R}$ Sample results are rejected

U Analyte was analyzed for, but not detected above the MDL, MDA, or LOD.

UI Gamma Spectroscopy-Uncertain identification

$X$ Consult Case Narrative, Data Summary package, or Project Manager conceruing this qualifier

$Y$ QC Sannples were not spiked with this compound

A RPD of sample and duplicate evaluated using $+/-\mathrm{RL}$. Concentrations are $<5 X$ the RL

h Preparation or preservation holding time was exceeded

The above sample is reported on a dry weight basis. 


\section{GENERAL ENGINEERING LABORATORIES, LLC \\ 2040 Savage Poad Charleston SC 29407 - (843) 556-8171 - www.gel.com}

\section{Certificate of Analysis}

Company: Bechel Nevada

Address: Warehouse 160. NTS 270

$\begin{array}{ll} & \text { Mercury, Novada } 89023 \\ \text { Contact: } & \text { Mr. Theodore Redding } \\ \text { Project: } & \text { Envirommental Rad Aralysis }\end{array}$

Repont Date: Junc 22, 2006

Client Sample ID:

Sample ID:

Matrix:

Collect Date:

Receive Date:

Collector:

SWMHZO0215
I63698003
Soil
18-MAY-06
25-MAY-06
Client

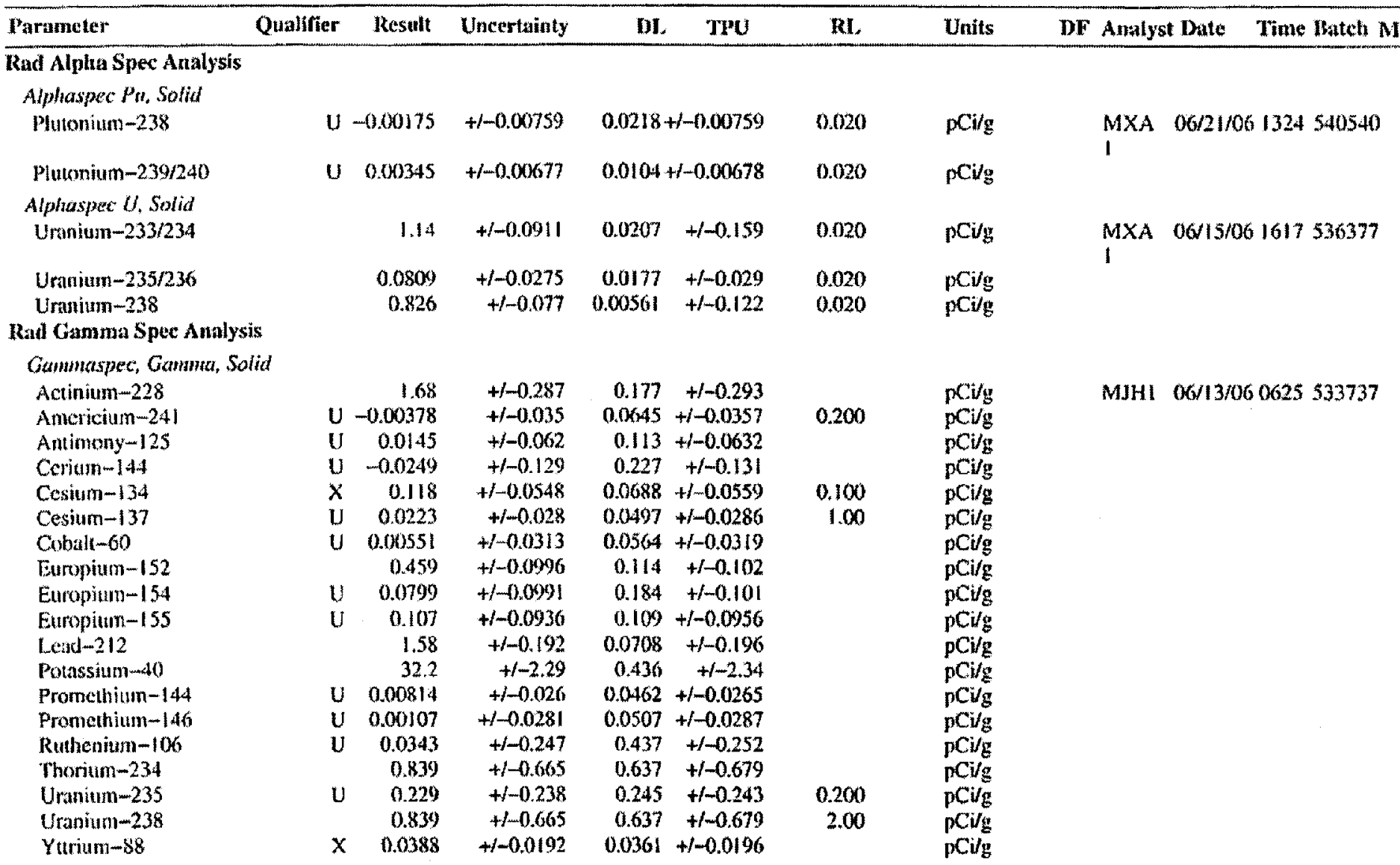

The Collowing Prep Methoils were performed

\begin{tabular}{llllll}
\hline Methed & Deseription & Analyst & Date & Time & Prep Batch \\
\hline Ash Soil Prep & Ash Soil Prep, GL-RAD-A-021B & AXP2 & $05 / 30 / 06$ & 1519 & 533869 \\
Diy Soil Prep & Dry Soil Prep GL-RAD-A-021 & LXM2 & $05 / 28 / 06$ & 1016 & 533732
\end{tabular}




\section{GENERAL ENGINEERING LABORATORIES, LLC}

2040 Savage Road Charleston SC 29407 - (843) 556-8171 - www.gel.com

\section{Certificate of Analysis}

Company: Bechtel Nevada

Address: Wardwouse 160, NTS 270

$\begin{array}{ll} & \text { Mercury. Nevada } 89023 \\ \text { Contact: } & \text { Mr. Theodore Rodding } \\ \text { Project: } & \text { Environmental Rad Analysis }\end{array}$

Report Date: June 22, 2006

Client Sample ID: SWMHZ00215

Sample ID:

163698003

Proiect: NEVAO0101

Clicnt ID: NEVAOO2

\begin{tabular}{lllllllll}
\hline Parameter & Qualifier & Result Uncertainty & DL. TPU & RI. & Units & DF Analyst Date Time Butch MI \\
\hline
\end{tabular}

The following Analylical Methods were performed

\begin{tabular}{ll}
\hline Method & Description \\
\hline 1 & DOE EML HASL-300, Pu-11-RC Modified \\
2 & DOE EML HASL-300, P1-11-RC Modified \\
3 & DOE EML HASL-300, U-02-RC Modified \\
4 & EML HASL 300, 4.5.2.3
\end{tabular}

\begin{tabular}{llcc} 
Surrogate/Tracer recovery & Test & Recovery\% & Acceptable Limits \\
\hline Plutonium-242 & Alphaspec Pu, Solid & 67 & $(15 \%-125 \%)$ \\
Uranim-232 & Alphaspec U. Solid & 65 & $(25 \%-125 \%)$
\end{tabular}

Notes:

The Qualifiers in this report are defined as follows :

* A quality control analyte recovery is outside of specificd acceptance criteria

$<$ Result is less than value reported

$>$ Result is greater than value reported

A The TIC is a suspected aldol-condensation product

B Target analyte was detected in the associated blank

BD Results are either below the MDC or tracer recovery is low

C Analyte has been confirmed by GCMS analysis

D Results are reported from a diluted aliquot of the sample

$H$ Analytical holding time was exceeded

J Value is estimated

N/A Spike recovery limits do not apply. Sample concentration exceeds spike concentration by $4 X$ or more

R Sample results are rejected

U Analyte was analyzed for, but not detected above the MDL, MDA, or LOD.

U1 Gamma Spectroscopy-Uncertain identification

$\mathrm{X}$ Consult Case Narrative, Data Summary package, or Project Manager concerning this qualifier

$Y$ QC Samples were not spiked with this compound

$\wedge$ RPD of sample and duplicate evaluated using $+/-\mathrm{RL}$. Concentrations are $<5 \mathrm{X}$ the RL.

h Preparation or preservalion holding time was cxceeded

The above sample is reponed on a dry weight basis. 


\title{
GENERAL ENGINEERING LABORATORIES, LLC
}

2040 Savage Hoad Charleston SC 29407 - (843) 556-8171 - www.gel.com

\section{Certificate of Analysis}

\author{
Company: Bechtel Nevada \\ Address: Warehowse 160, NTS 270

$\begin{array}{ll} & \text { Mercury, Nevada } 89023 \\ \text { Contact: } & \text { Mr. Theodore Redding } \\ \text { Project: } & \text { Environmental Rad Analysis }\end{array}$

Repon Date: June 22,2006

Client Sample ID:

Sample ID:

Matrix:

Collect Date:

Receive Date:

Collector:

SWMHZOO216
163698004
Soil
18-MAY-O6
25-MAY-06
Client

Proiect: NEVAO0101

Client ID: NEVAOO2

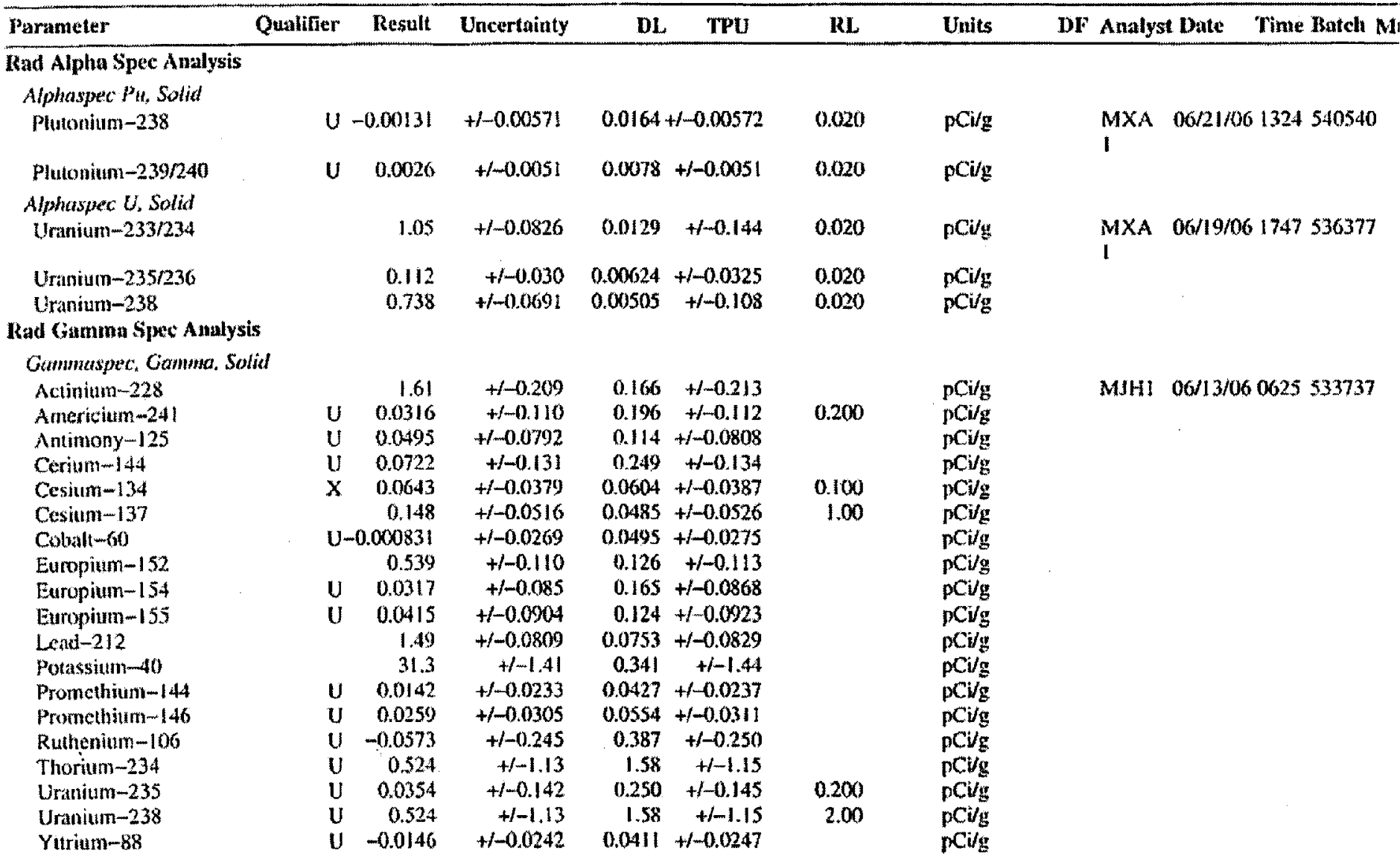

The following l'rep Methods were performed

\begin{tabular}{llllll}
\hline Method & Description & Analyst & Date & Time & Prep Batch \\
\hline Ash Soil Prep & Ash Soil Prep, GL-RAD-A-021B & AXP2 & $05 / 30 / 06$ & 1519 & 533869 \\
Dry Soil Prep & Dry Soil Prep GL-RAD-A-121 & LXM2 & $05 / 28 / 06$ & 1016 & 533732
\end{tabular}




\title{
GENERAL ENGINEERING LABORATORIES, LLC \\ 2040 Savage Road Charleston SC 29407 - (843) 556-8171 - www.gel.com
}

\section{Certificate of Analysis}

\author{
Company: Bechiel Nevada \\ Address: Warehouse 160, N'TS 270
Mercury, Nevada 89023
Contact: Mr. Theodore Reddling
Projeer: Envirommental Rad Analysis

Report Date: June 22.2006

Client Sample ID: SWMHZ00216 Proiect: NEVA00101

Sample ID: $\quad 163698004$

Clienl ID: NEVAOO2

\begin{tabular}{lllllllll}
\hline Parameter & Qualifier & Resulf & Uncertainty & OL & TPU & RL & Units & DF Analyst Date Time Bateh Mi \\
\hline
\end{tabular}

The following Analytical Methods were perlormed

\begin{tabular}{ll} 
Method & Description \\
\hline 1 & DOE EML HASL-300, Pu-11-RC Modified \\
2 & DOE EML HASL-300, PU-11-RC Modified \\
3 & DOE EML HASL-300, U-02-RC Modified \\
4 & EML HASL 300, 4.5.2.3
\end{tabular}

\begin{tabular}{llcc} 
Surrogate/Tracer recovery & Nest & Recovery $\%$ & Acceptable Limits \\
\hline Plutonium-242 & Alphaspec Pu, Solid & 87 & $(15 \%-125 \%)$ \\
Uranium-232 & Alphaspec U, Solid & 70 & $(25 \%-125 \%)$
\end{tabular}

Notes:

The Qualifiers in this report are defined as follows:

- A quality control analyle recovery is outside of specified acceptance criteria

$<$ Result is less than value reported

$>$ Result is greater than value reported

A The TIC is a suspected aldol-condensation product

B Target analyte was detected in the associated blank

$\mathrm{BD}$ Results are either below the MDC or tracer recovery is low

C Analyte has been confirmed by GCMS analysis

D Results are reponed from a diluted aliquot of the sample

$H$ Analytical holding time was exceeded

I Value is estimated

N/A Spike recovery limits do not apply. Sample concentration exceeds spike concentration by $4 X$ or more

$\mathrm{R}$ Sample results are rejected

U Analyte was analyzed for, but not detected above the MDL, MDA, or LOD.

Ul Gamma Spectroscopy-Uncertain identification

X Consult Case Narrative, Data Summary package, or Project Manager concerning this qualifier

$Y$ QC Samples were not spiked with this compound

* RPD of sample and duplicate evaluated using $+/-\mathrm{RL}$. Concentrations are $<S \mathrm{X}$ the $\mathrm{RL}$

h Preparation or preservation holding time was excceded

The above sample is reported on a dry weight basis. 


\section{GENERAL ENGINEERING LABORATORIES, LLC}

\section{Certificate of Analysis}

Company: Bechtel Nevada

Address: Warehouse 160 . NTS 270

$\begin{array}{ll} & \text { Mercury, Nevada } 89023 \\ \text { Contaca: } & \text { Mr. Theodore Redding } \\ \text { Project: } & \text { Environmental Rad Analysis }\end{array}$

Report Date: June 22.2006

Client Sample ID:

Sample ID:

Matrix:

Collect Date:

Receive Dat::

Collector:

SWMHZ00217
163698005
Soil
18-MAY-06
25-MAY-06
Client

SWMHZ00217

163698005

18-MAY-06

Client

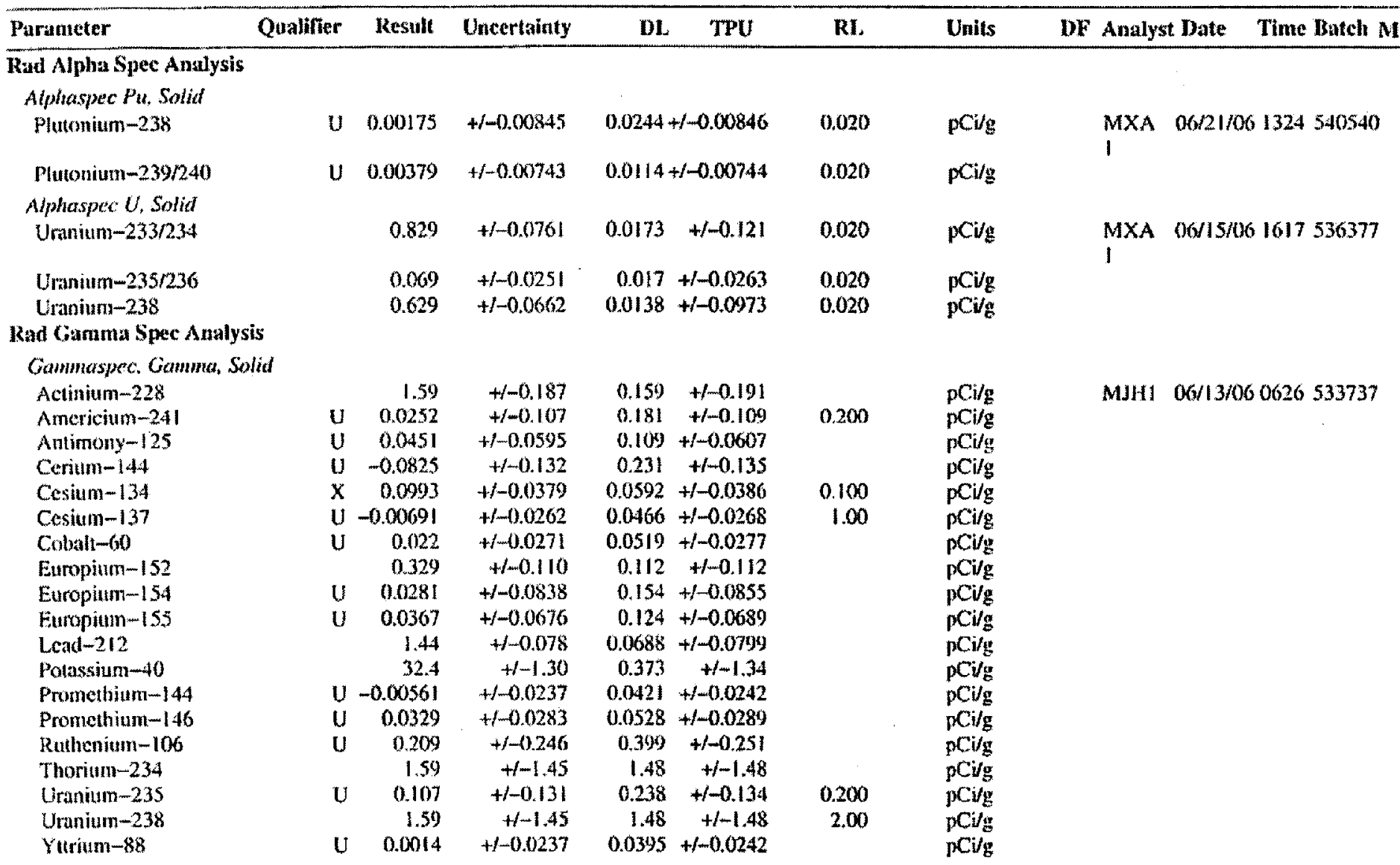

The following Prep Methods were performed

\begin{tabular}{llllll}
\hline Mhethod & Description & Analyst & Dale & Time & Prep Bateh \\
\hline Ash Soil Prep & Ash Soil Prep, GL-RAD-A-ODIB & AXP2 & $05 / 30 / 06$ & 1519 & 533869 \\
Dry Soil Prep & Dry Soil Prep GL-RAD-A-021 & LXM2 & $05 / 28106$ & 1016 & 533732
\end{tabular}




\section{GENERAL ENGINEERING LABORATORIES, LLC \\ 2040 Savage Road Charleston SC 29407 - (843) 556-8171 - www.gel.com}

\section{Certificate of Analysis}

Company: Bechiel Nevada

Address: Warchouse 160, NTS 270

$\begin{array}{ll} & \text { Mercury, Nevada } 89023 \\ \text { Contact: } & \text { Mr. Theodore Redding } \\ \text { Project: } & \text { Environmental Rad Analysis }\end{array}$

Report Date: June 22, 2006

Client Sample ID: $\quad$ SWMHZ00217

Sample 10:

163698005

Proiect: NEVAOO101

Client ID: NEVAOO2

\begin{tabular}{|c|c|c|c|c|c|c|c|c|}
\hline Parameter & Qualifier & Result Uncertainty & DL & TPU & $\mathbf{R L}$ & Units & DF Annlyst Date & Time Bateh $N$ \\
\hline \multicolumn{9}{|c|}{ The following Analytical Methods were performed } \\
\hline Methnd & Description & & & & & & & \\
\hline 1 & DOE EML HASL- & 100. Pu-11-RC Modificd & & & & & & \\
\hline 2 & DOE EML HASL- & 00, Pu-11-RC Modified & & & & & & \\
\hline 3 & DOE EML HASL- & (00, U-1)2-RC Moditted & & & & & & \\
\hline 4 & EML. HASL 300,4 & 5.2 .3 & & & & & & \\
\hline
\end{tabular}

\begin{tabular}{llcc} 
Surrogate/Tracer recovery & Test & Recovery\% & Acceptable Limits \\
\hline Plutonium-242 & Alphaspec P'u, Solid & 58 & $(15 \%-125 \%)$ \\
Uranium -232 & Alphaspec U, Solid & 65 & $(25 \%-125 \%)$
\end{tabular}

Notes:

The Qualifiers in this report are defined as follows:

* A quality control analyte recovery is outside of specified acceptance criteria

$<$ Result is less than value reported

$>$ Result is greater than value reported

A The TIC is a suspected aldol-condensation product

13 Target analyte was detected in the associated blank

$\mathrm{BD}$ Results are either below the MDC or tracer recovery is low

C Analyte has been confimed by GC/MS analysis

D Results are reported from a diluted aliquol of the sample

H Analytical holding time was exceeded

$\mathrm{J}$ Value is estimated

N/A Spike recovery limits do not apply. Sample concentration exceeds spike concentration by $4 X$ or more

$R$ Sample results are rejected

U Analyte was analyzed for, but nol detected above the MDL. MDA, or LOD.

UI Gamma Spectroscopy-Uncertain identification

$X$ Consult Case Narrative, Data Summary package, or Project Manager comcerning this qualifier

$\mathrm{Y}$ QC Samples were not spiked with this compound

A RPD of sample and duplicate evaluated using $+/-\mathrm{RL}$. Concentrations are $\angle 5 \times$ the $\mathrm{RL}$

$\mathrm{h}$ Preparation or preservation holding time was exceeded

The above sample is reponted on a dry weight basis. 


\section{GENERAL ENGINEERING LABORATORIES, LLC \\ 2040 Savage Road Charleston SC 29407 - (843) 556-8171 - www.gel.com}

\section{Certificate of Analysis}

Company: Bechtel Nevada

Address: $\quad$ Warehouse 160, NTS 270

$\begin{array}{ll} & \text { Mercury, Nevida } 89023 \\ \text { Contat: } & \text { Mr. Theodore Redding } \\ \text { Project: } & \text { Environmental Rad Analysis }\end{array}$

Report Date: June 22, 2006

Client Sample ID:

Sample ID:

Matrix:

Collect Date:

Receive Date:

Collector:

SWMHZO0218
163698006
Soil
18-MAY-06
25-MAY-06
Client

SWMHZOO218

163698006

18-MAY-06

Client

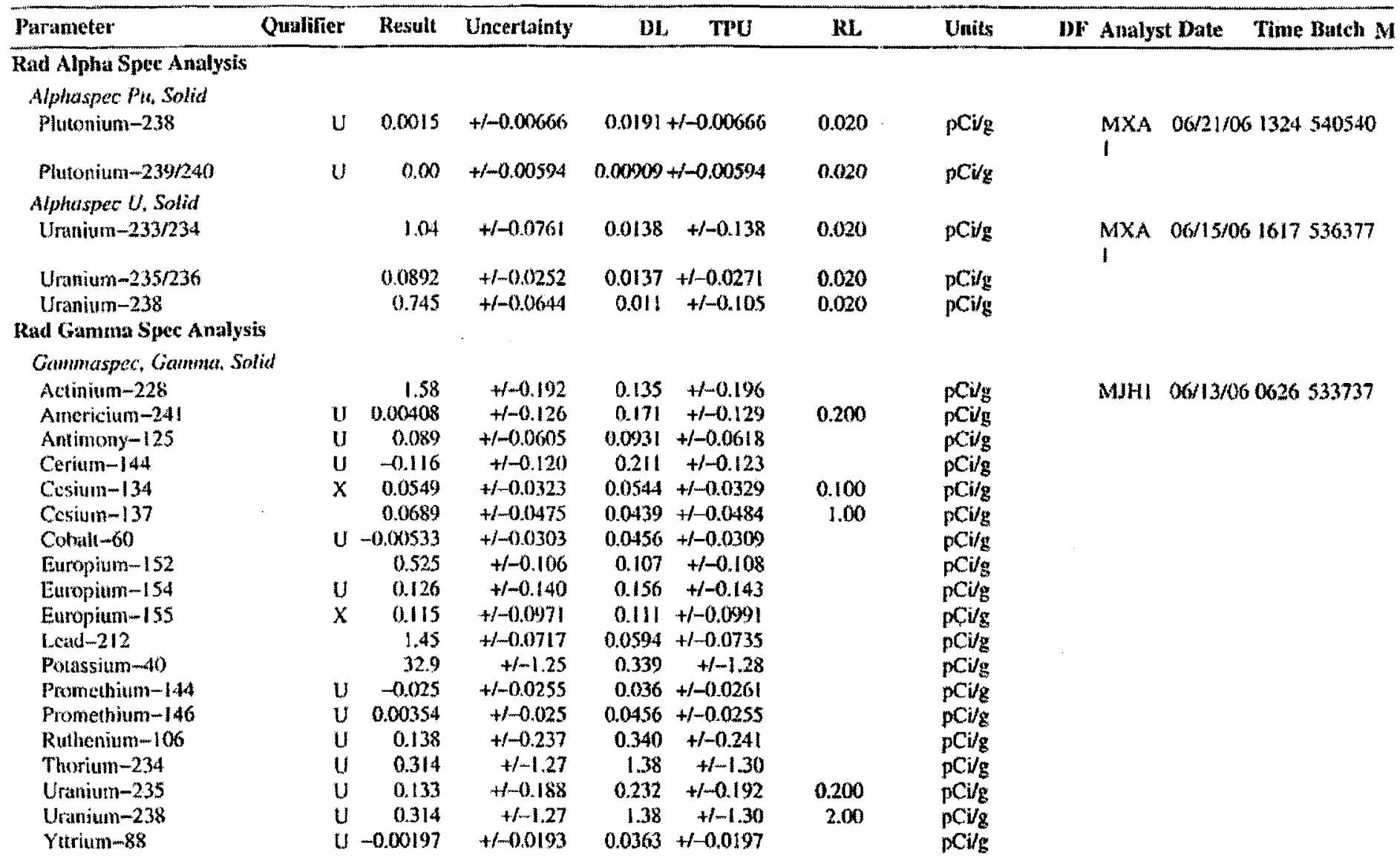

The following Prep Methods wure performed

\begin{tabular}{llllll}
\hline Method & Descripliod & Analyst & Date & Time & Prep Bateh \\
\hline Ash Soil Prep & Ash Soil Prep, GL-RAD-A-021B & AXP2 & 05/30166 & 1519 & 533869 \\
Dry Soil Prep & Dry Soil Prep GL-RAD-A-021 & LXM2 & $05 / 28 / 66$ & 1016 & 533732
\end{tabular}




\section{GENERAL ENGINEERING LABORATORIES, LLC \\ 2040 Savage Road Charleston SC 29407 - (843) 556-8171 - www.gel.com}

\section{Certificate of Analysis}

Company: Beclitel Nerada

Address: Warehouse 160, NTS 270

$\begin{array}{ll} & \text { Mercury, Nevada } 89023 \\ \text { Contact: } & \text { Mr. Theodore Redding } \\ \text { Project: } & \text { Environmental Rad Analysis }\end{array}$

Repon Dale: June 22, 2006

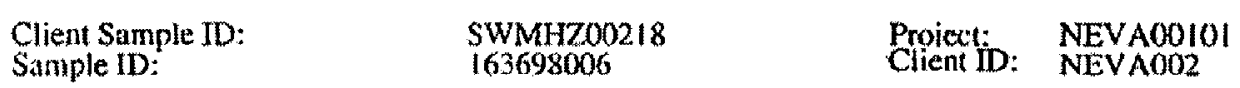

\begin{tabular}{|c|c|c|c|c|c|c|}
\hline Parameter & Qualifier & Result Uncertainty & DI TPU & Units & DF Analyst Date & Tine Batch M \\
\hline \multicolumn{7}{|c|}{ The following Analytical Methods were performed } \\
\hline Method & Description & & & & & \\
\hline 1 & DOE EML HASL-? & 00. Pu-11-RC Modified & & & & \\
\hline 2 & DOE EML HASL- & W), Pu-11-RC Modified & & & & \\
\hline 3 & DOE EML. HASL-: & 00, U-02-RC Modilied & & & & \\
\hline 4 & EML HASL 300,4 & 2.3 & & & & \\
\hline
\end{tabular}

\begin{tabular}{llcc} 
Surrogatef Tracer recovery & Test & Recovery\% & Acceptable Limits \\
\hline Plutonium-242 & Alphaspee Pu, Solid & 76 & $(15 \%-125 \%)$ \\
Uranium-232 & Alphaspec U, Solid & 79 & $(25 \%-125 \%)$
\end{tabular}

Notes:

The Qualifiers in this report are defined as follows:

* A quality control analyte recovery is outside of specified acceptance eriteria

$<$ Result is less than value reported

$>$ Result is greater than value reported

A The TIC is a suspected aldol-condensation prodict

B Target analyte was detected in the associated blank

$\mathrm{BD}$ Results are either below the MDC or tracer recovery is low

C Analyte bas been confirmed by GCMS analysis

D Resulis are reported from a diluted aliguot of the sample

H Analytical holding time was exceeded

J Value is estimated

N/A Spike recovery limits do not apply. Sample concentration exceeds spike concentration by $4 X$ or more

$\mathrm{R}$ Sample results are rejected

4 Analyte was analyzed for, but not detected above the MDL, MDA, or LOD.

Ul Gamma Spectroscopy-Uncertain identification

$X$ Consult Case Narrative, Data Summary package, or Project Manager concerning this qualifier

Y QC Samples were not spiked with this compound

$\wedge$ RPD of sample and duplicate evaluated asing $+/-\mathrm{RL}$. Concentrations are $\delta \mathrm{X}$ the $\mathrm{RL}$

h Preparation or preservation lolding time was excecded

The above sample is reported on a dry weight basis. 


\section{GENERAL ENGINEERING LABORATORIES, LLC}

2040 Savage Road Charleston SC 29407 - (843) 556-8171 - www.gel.com

\section{Certificate of Analysis}

Company: Bechtel Nevada

Address: Warchouse 160, NTS 270

$\begin{array}{ll} & \text { Mercury. Nevada } 89023 \\ \text { Contact: } & \mathrm{Mr} \text {. Theodore Redthing } \\ \text { Projed: } & \text { Envirmmenal Rad Analysis }\end{array}$

Report Date: Junc 22, 2006

Project: Envirmmenal Rad Analysis

Client Sample ID

Sample ID:

Matrix:

Collect Date:

Receive Date:

Collector:

SWMHZ00219
163698007
Soil
$18-\mathrm{MAY}-06$
$25-\mathrm{MAY}-06$
Client

SWMHZO0219

16369800

$18-M A Y-06$

Client

\begin{tabular}{|c|c|c|c|c|c|c|c|c|c|c|}
\hline \multirow{2}{*}{$\frac{\text { Parameter }}{\text { Rad Alpha Spec Analys }}$} & Qualifier & \multirow[t]{2}{*}{ Resull } & \multirow[t]{2}{*}{ Uncertainty } & \multirow{2}{*}{\multicolumn{2}{|c|}{ DL }} & \multirow[t]{2}{*}{ RL. } & \multirow[t]{2}{*}{ Units } & \multirow[t]{2}{*}{ Dr } & Analyst Date & \multirow[t]{2}{*}{ Time Batch Mi } \\
\hline & & & & & & & & & & \\
\hline Alphaspec Pu, Sold & & & & \multirow{2}{*}{\multicolumn{2}{|c|}{$0.008+1-0.00741$}} & & & & & \\
\hline Plutonium-238 & $\mathbf{U}$ & 0.00533 & $+1-0.00739$ & & & 0.020 & $\mathrm{pCi} / \mathrm{g}$ & & $\underset{1}{\mathrm{MXA}} \quad 06 / 21 \mathrm{H}$ & 61324540540 \\
\hline Plutorium-239/240 & $\mathrm{u}$ & 0.00 & $+1-0.00522$ & \multicolumn{2}{|c|}{$0,00799+1-0,00522$} & 0.020 & $\mathrm{pCi} / \mathrm{a}$ & & & \\
\hline \multicolumn{11}{|l|}{ Alphaspec U. Solid } \\
\hline Uranium $-233 / 234$ & & 0.933 & $+1-0.0907$ & 0.0175 & $+1-0.142$ & 0,020 & $\mathrm{pCi} / \mathrm{g}$ & & $\underset{1}{\mathrm{MXA}} \quad 06 / 15 /$ & 161617536377 \\
\hline Uranium $-235 / 236$ & & 0.0705 & $+1-0.0276$ & 0.00846 & $+1-0.0289$ & 0.020 & $\mathrm{pCl} / \mathrm{g}$ & & & \\
\hline Uranium-238 & & 0.730 & $+1-0.0805$ & 0.0219 & $+/-0.117$ & 0.020 & $\mathrm{pCig}$ & & & \\
\hline \multicolumn{11}{|c|}{ Kad Gamma Spec Analysis } \\
\hline \multicolumn{11}{|c|}{ Gammetspec, Gamma, Solid } \\
\hline Actúnimn-228 & & 1.54 & $+1-0.258$ & 0.158 & $+1-0.264$ & & $p C i / g$ & & MJHI $06 / 13 / \mathrm{C}$ & $60627 \$ 33737$ \\
\hline Americium-241 & $U$ & -0.0229 & $+1-0.122$ & 0.231 & $+1-0.124$ & 0.200 & $\mathrm{pCi} / \mathrm{g}$ & & & \\
\hline Antimony-125 & $\mathbf{U}$ & 0.0022 & +0.053 & 0.0967 & $+1-0.0541$ & & $\mathrm{pCi} / \mathrm{g}$ & & & \\
\hline Ceriun- -14 & $\mathbf{U}$ & 0.00519 & $+1-0.119$ & 0.217 & $+1-0.121$ & & $\mathrm{pCi} / \mathrm{g}$ & & & \\
\hline Cesium-134 & $x$ & 0.132 & $+1-0.0519$ & 0,0602 & $+1-0.0529$ & 0.100 & $p C \mathrm{ig}$ & & & \\
\hline Cesium-137 & $\mathrm{U}$ & 0.0227 & $+1-0.0305$ & 0.0417 & $+/-0.0312$ & 1.00 & $\mathrm{pCi} / \mathrm{g}$ & & & \\
\hline Cobalt -60 & $\mathrm{U}$ & 0.0261 & $+/-0.0265$ & 0.0503 & $+1-0.027$ & & $\mathrm{pCi} / \mathrm{g}$ & & & \\
\hline Europium-152 & & 0.444 & +-0.113 & 0.108 & $+/-0.115$ & & $\mathrm{pCi} / \mathrm{g}$ & & & \\
\hline Europiam-154 & $\mathrm{U}$ & 0.00829 & $+1-0.087$ & 0.154 & $+/-0.0887$ & & $\mathrm{pCi} / \mathrm{g}$ & & & \\
\hline Europiam-155 & $\mathrm{U}$ & 0.0434 & $+1-0.066$ & 0.124 & $+1-0.0674$ & & $\mathrm{pCi} / \mathrm{g}$ & & & \\
\hline Letu-212 & & 1.91 & $+1-0.141$ & 0.0637 & $+/-0.143$ & & $\mathrm{pCi} g$ & & & \\
\hline Puassium-40 & & 33.7 & $+1-2.46$ & 0.317 & $+/-2.51$ & & $\mathrm{pCi} / \mathrm{g}$ & & & \\
\hline Promethium-144 & u & 0.00878 & $+/-0.0229$ & 0.0408 & +-0.0233 & & $\mathrm{pCi} / \mathrm{g}$ & & & \\
\hline Promethiusn-140 & U & 0.00602 & $+/-0.0252$ & 0.0462 & $+1-0.0257$ & & $\mathrm{mCi} / \mathrm{g}$ & & & \\
\hline Ruthenium-10\% & $\mathrm{U}$ & -0.0384 & $+/-0.199$ & 0.340 & $+f-0.203$ & & $\mathrm{pCig}$ & & & \\
\hline Thonium-234 & U & 0.675 & $+1-1.32$ & 1.78 & $+1-1.35$ & & $\mathrm{pCi} / \mathrm{g}$ & & & \\
\hline Uranium-235 & $\mathrm{U}$ & 0.0386 & $+1-0.118$ & 0.216 & $+1-0.121$ & 0.200 & $\mathrm{pCi} / \mathrm{g}$ & & & \\
\hline Uranitun-238 & U & 0.675 & $+1-1.32$ & 1.78 & $+1-1.35$ & 2.00 & $\mathrm{pCv} / \mathrm{g}$ & & & \\
\hline Yurium-88 & $\mathrm{u}$ & -0.00414 & $+1-0.0233$ & 0.0365 & $+1-0.0237$ & & pCig & & & \\
\hline
\end{tabular}

The following Irep Methods were performed

\begin{tabular}{llllll} 
Method & Description & Analyst & Date & Time & Wrep Batch \\
\hline Ash Soil Prep & Ash Soil Prep, GL-RAD-A-021B & AXP2 & $05 / 30 / 06$ & 1519 & 533869 \\
Dry Sovil Prep & Dry Soil Prep GL-RAD-A-021 & LXM2 & $05 / 28 / 06$ & 1016 & 533732
\end{tabular}




\section{GENERAL ENGINEERING LABORATORIES, LLC}

2040 Savage Road Charleston SC 29407 - (843) 556-8171 - www.gel.com

\section{Certificate of Analysis}

Company: Bechtel Nevada

Address: Warehouse 160. NTS 270

$\begin{array}{ll} & \text { Mercury. Nevada } 89023 \\ \text { Contact: } & \text { Mr. Theodore Redding } \\ \text { Project: } & \text { Environmental Rad Analysis }\end{array}$

Report Date: June 22, 2006

Client Sample ID:

Sample ID:

SWMHZOY0219

Proiect: NEVAO0101

163698007

Client ID: NEVA002

\begin{tabular}{|c|c|c|c|c|c|c|c|c|}
\hline Parameter & Qualifier & Result Uncertainty & DI. & TPU & $\mathbf{R L}$ & Units & DF Analyst Date & Time Bateh $\mathrm{N}$ \\
\hline \multicolumn{9}{|c|}{ The following Analytical Methods were performed } \\
\hline Method & Description & & & & & & & \\
\hline 1 & DOE EML HASL & 00, Pu-11-RC Modified & & & & & & \\
\hline 2 & DOE EML HASL- & Do, Py-11-RC Modified & & & & & & \\
\hline 3 & DOE EML HASL- & 00. U-02-RC Modilied & & & & & & \\
\hline 4 & EML HASL 300,4 & .2 .3 & & & & & & \\
\hline
\end{tabular}

\begin{tabular}{llcc} 
Surrogater Tracer recovery & Test & Recovery\% & Acceptable Limits \\
\hline Plutonium-242 & Alphaspec Pu, Solid & 89 & $(15 \%-125 \%)$ \\
Uranium-232 & Alphaspec U, Solid & 50 & $(25 \%-125 \%)$
\end{tabular}

Notes:

The Qualifiers in this report are defined as follows :

* A quality control amalyte recovery is outside of specified acceptance criteria

$<$ Result is less than value reponted

$>$ Result is greater than value reported

A The TIC is a suspected aldol-condensation product

B Target analyte was detected in the associated blank

BD Results are either below the MDC or tracer recovery is low

C Analyte has been confirmed by GCMS analysis

D Results are reported from a diluted aliquot of the sample

H Analytical holding time was exceeded

J Value is estimated

N/A Spike recovery limits do not apply. Sumple concentration exceeds spike concentration by $4 X$ or more

$\mathrm{R}$ Sample results are rejected

U Amalyte was analyzed for, but nol detected above the MDL, MDA, or LOD.

UI Gamma Spectroscopy-Uncertain identification

$X$ Consult Case Narrative, Data Summary package, or Project Manager conceming this qualifier

$Y$ QC Samples were not spiked with this compound

$\wedge$ RPD of sample and duplicate evaluated using $+1-\mathrm{RL}$. Concentrations are $<5 \times$ the RL

h Preparation or preservation holding lime was excexded

The atove sample is reported on a dry weiglit basis. 


\section{GENERAL ENGINEERING LABORATORIES, LLC}

2040 Sayage Pload Charleston SC 29407 - (843) 556-8171 - www.gel.com

\section{Certificate of Analysis}

Company: Bechtel Nevada

Address: Warehouse 160 , NTS 270

$\begin{array}{ll} & \text { Mercury, Nevada } 89023 \\ \text { Contact: } & \text { Mr. Theodore Redding } \\ \text { Project: } & \text { Environmental Rad Allalysis }\end{array}$

Report Date: June 22, 2006

Client Sample ID:

Sample ID:

Matrix:

Collect Date:

Receive Date:

Collector:

SWMHZ00220
163698008
Soil
$18-M A Y-06$
$25-M A Y-06$
Client

SWMHZ00220

163698008

18-MAY -06

Client

\begin{tabular}{|c|c|c|c|c|c|c|c|c|c|c|c|}
\hline Paraneter & Qualifier & Resuli & Uncertainty & DI. & $\mathbf{T}^{2} \mathbf{U}$ & RL. & Units & DP & Aualyst & Dale & Time Bateh M \\
\hline \multicolumn{12}{|c|}{ Rad Alpha Spec Analysis } \\
\hline \multicolumn{12}{|c|}{ Alptraspec Pu, Solid } \\
\hline Plutonium -238 & $\mathrm{u}$ & 0.00 & $+/=0.00524$ & \multicolumn{2}{|c|}{$0.00802+1-0.00524$} & 0.020 & $\mathrm{pCi} / \mathrm{g}$ & \multirow{2}{*}{\multicolumn{2}{|c|}{$\begin{array}{l}\text { MXA } \\
1\end{array}$}} & $06 / 21 / 0$ & 161324540540 \\
\hline Plutonium-239r240 & $\mathbf{U}$ & 0.00534 & $+1-0.0074$ & $0.00801+$ & $+1-0.00742$ & 0.020 & $\mathrm{pCi} / \mathrm{g}$ & & & & \\
\hline \multicolumn{12}{|l|}{ Alphaspec $U$. Solid } \\
\hline Uraniun-233/234 & & 1.09 & $+1-0.121$ & 0.0331 & $+1-0.183$ & 0.020 & $\mathrm{pCi} / \mathrm{g}$ & \multirow{3}{*}{\multicolumn{2}{|c|}{$M \times A$}} & $06 / 15 / 0$ & 61617536377 \\
\hline Uranium $-235 / 236$ & & 0.115 & $+/-0.0435$ & 0.0128 & $+1-0.0458$ & 0.020 & $\mathrm{pCi} / \mathrm{g}$ & & & & \\
\hline Uranium-238 & & 0.749 & $+1-0.0997$ & 0.0104 & +0.137 & 0.020 & $\mathrm{pCig}$ & & & & \\
\hline \multicolumn{12}{|c|}{ Rat Camma Spec Analysis } \\
\hline \multicolumn{12}{|c|}{ Gammouspec, Gummas. Solid } \\
\hline Actinium-228 & & 1.40 & $+1-0.214$ & 0.142 & $+1-0.219$ & & $\mathrm{pCi} / \mathrm{g}$ & \multirow{19}{*}{\multicolumn{2}{|c|}{ MUHI }} & $06 / 13 / 0$ & 60627533737 \\
\hline Americium-241 & $\mathbf{U}$ & 0.0911 & $+1-0.106$ & 0.182 & $+1-0.108$ & 0,200 & $\mathrm{pCig}$ & & & & \\
\hline Antimony-125 & $\mathrm{U}$ & 0.0285 & $+1-0.0505$ & 0.102 & $+1-0.0516$ & & $\mathrm{pCi} / \mathrm{g}$ & & & & \\
\hline Cerium-144 & $\mathrm{U}$ & -0.0825 & $+1-0.134$ & 0.244 & $+1-0.137$ & & $\mathrm{pCi} / \mathrm{g}$ & & & & \\
\hline Cosium-134 & $\mathrm{U}$ & 0.0388 & $+1-0.0447$ & 0.0441 & $+1-0.0456$ & 0.100 & pCirg & & & & \\
\hline Cesian-137 & U & 0.0414 & $+1-0.0387$ & 0.0439 & $+1-0.0394$ & 1.00 & $\mathrm{pCV} / \mathrm{g}$ & & & & \\
\hline Coball -60 & $\mathrm{v}$ & 0.00417 & $+i-0.0246$ & 0.0441 & $+1-0.0251$ & & $\mathrm{pCi} / \mathrm{g}$ & & & & \\
\hline Europium-152 & & 0.389 & $+1-0.110$ & 0.115 & $+1-0.112$ & & pCig & & & & \\
\hline Europium-154 & $\mathrm{u}$ & 0.0681 & $+1-0.0924$ & 0.147 & $+1-0.0943$ & & $\mathrm{pCi} / \mathrm{g}$ & & & & \\
\hline Europium-155 & $\mathbf{u}$ & 0.104 & $+1-0.0831$ & 0.123 & $+1-0.0848$ & & $\mathrm{pCi} / \mathrm{g}$ & & & & \\
\hline Lead-2/2 & & 1.47 & $+1-0.0735$ & 0.0642 & $+1-0.0753$ & & $\mathrm{pCi} g$ & & & & \\
\hline Polassiun- 40 & & 31.2 & $+/-1.18$ & 0.346 & $+1-1.22$ & & $\mathrm{pCi} / \mathrm{g}$ & & & & \\
\hline Promethium-1 44 & $\mathrm{u}$ & 0.0198 & $+1-0.0221$ & 0.0418 & $+1-0.0226$ & & $\mathrm{pug}$ & & & & \\
\hline Promahium-146 & u & -0.00037 & $+1-0.0314$ & 0.0479 & +-0.0321 & & $\mathrm{pCi} g$ & & & & \\
\hline Ruthenium-106 & U & -0.224 & $+1-0.202$ & 0.348 & $+1-0.206$ & & $\mathrm{pCv} / \mathrm{g}$ & & & & \\
\hline Thorium-234 & & 1.49 & $+1-1.30$ & 1.48 & $+1-1.33$ & & $\mathrm{pCi} / \mathrm{g}$ & & & & \\
\hline Uratium-235 & & 0.420 & $+1-0.218$ & 0.248 & $+1-0.223$ & 0.200 & $\mathrm{pCi} / \mathrm{g}$ & & & & \\
\hline Uranitum-238 & & 1.49 & $+1-1.30$ & 1.48 & $+1-1.33$ & 2.00 & $\mathrm{pCi} / \mathrm{g}$ & & & & \\
\hline Yutrium-88 & u & -0.00331 & $+1-0.0206$ & 0.038 & $+/-0.021$ & & $\mathrm{pCi} / \mathrm{g}$ & & & & \\
\hline
\end{tabular}

The following Prep Methods were performed

\begin{tabular}{llllll}
\hline Methed & Description & Analyst & Date & Time & Prep Batch \\
\hline Asli Soil Prep & Ash Soil Prep, GL_-RAD-A-021B & AXP2 & $05 / 30106$ & 1519 & 533869 \\
Dry Soil Prop & Dry Soil Prep GL-RAD-A-021 & LXM2 & $05 / 28 / 06$ & 1016 & $\$ 33732$
\end{tabular}




\section{GENERAL ENGINEERING LABORATORIES, LLC \\ 2040 Savage Road Charleston SC 29407 - (843) 556-8171 - www.gel.com}

\section{Certificate of Analysis}

Company: Bechel Nevada

Address: Warchouse 160 , NTS 270

$\begin{array}{ll} & \text { Mercury, Nevada } 89023 \\ \text { Contact: } & \text { Mr. Theodore Redding } \\ \text { Project: } & \text { Enviromental Rad Analysis }\end{array}$

Report Date: June 22, 2006

Client Sample ID:

Sample ID:

SWMHZ00220

163698008

Proicct: NEVAOD101

Client ID: NEVAOO2

\begin{tabular}{llllllll}
\hline Parameter & Qualfier Result Uncertainty & DL & TPU & RL & Units & DF Analyst Date Time Batch M \\
\hline
\end{tabular}

The following Analytical Methods were performed

\begin{tabular}{ll} 
Method & Deseription \\
\hline 1 & DOE EML HASL-300. P1-11-RC Modified \\
2 & DOI LML. HASI,-300, PU-11-RC Modified \\
3 & DOE EML. HASL-300, U-02-RC Modified \\
4 & EML HASL 300.4.5.2.3
\end{tabular}

\begin{tabular}{llcc} 
Surrogate/lincer recovery & Test & Recovery \% & Acceptable Limits \\
\hline Plutonium -242 & Alphaspec Pu. Solid & 87 & $(15 \%-125 \%)$ \\
Uranium-232 & Alphaspec U. Solid & 34 & $(25 \%-125 \%)$
\end{tabular}

Notes:

The Qualifiers in this report are defined as follows:

* A quality control andyte recovery is ontsitle of specified acceptance criteria

$<$ Result is less than value reported

$>$ Result is greater than value reported

A The TIC is a suspected aldol-condensation product

B Target analyte was detected in the associated blank

BD Results are either below the MDC or tracer recovery is low

C Analyte has been contirmed by GC/MS analysis

D Results are reported from a difuted aliquot of the sample

$\mathrm{H}$ Analytical holding time was exceeded

$J$ Valuc is estimated

N/A Spike recovery limits do not apply. Sample concentration exceeds spike concentration by $4 X$ or more

$R$ Sample results are rejected

U Amalyle was analyzed for, but not detected above the MDL, MDA, or LOD.

UI Gamma Spectroscopy--Uncertain identification

$X$ Cousult Case Narrative, Data Summary package, or Project Mamager concerning this qualifier

$Y$ QC Samples were not spiked with this compound

$\wedge$ RPD of sample and duplicale evaluated using $+/-$ RL. Concentrations are $<5 X$ the RL

h Preparation or preservation holding time was exceeded

The above sample is reported on a dry weight basis. 
Closure Report - CAU 528

Section: Appendix B

Revision: 0

Date: September 2006

THIS PAGE INTENTIONALLY LEFT BLANK 
Date: September 2006

\section{APPENDIX C}

\section{WASTE DISPOSITION DOCUMENTATION}


Closure Report - CAU 528

Section: Appendix C

Revision: 0

Date: September 2006

\section{THIS PAGE INTENTIONALLY LEFT BLANK}




\section{NTS LANDFILL LOAD VERIFICATION}

(Waste definitions are available on page 2)

\begin{tabular}{|c|c|c|c|}
\hline SWO USE (Select One) AREA $\square 23$ & $\square 6$ & LANDFILL \\
\hline For waste characterization, approval, and/or assistance, contact Solid Waste Operation (SWO) at 5-7898. \\
REQUIRED: WASTE GERERATOR INFORMATION \\
(This form is for rolloffs, dump trucks, and other onsite disposal of materials.)
\end{tabular}

Waste Generator: Michacl Casselbury Phone Number: $295-2727$ Location/Origin: NTS Area 25, Test Cell C CAU 528

Waste Category: (check one) $\square$ Commercial $\quad \square$ Industrial

Waste Type: \NTS $\square$ Putrescrible $\square$ FFACO-onsite $\square$ WAC Exception

(check one) $\square$ Non-Putrescible $\square$ Asbestos Containing Material $\square$ FFACO-offsite $\square$ Historic DOENN

Pollution Prevention Category: (check one) $\triangle D$ Environmental management $455^{3} \square$ Defense Projects $\square$ YMP

Pollution Prevention Category: (check one) $\otimes$ clean-Up $\quad \zeta / 23 / 60$ Routine

Method of Characterization: (check one) $邓$ Sampling \& Analysis $\square$ Process Knowledge $\square$ Contents

Prohibited Waste at all three Radioactive wasle; RCRA waste; Hazardous waste; Free liquids, PCBs above TSCA regulatory NTS landfills: levels, and Medical wastes (needles, sharps, bloody clothing).

Additional Prohibited Waste Sewage Sludge. Animal carcasses. Wet garbage (food waste); and Friable asbestos

at the Area 9 U10C Landfil:

Check all allowable wastes that are contained within this load.

NOTE: Waste disposal at the Area 6 Hydrocarbon Landfill must have come into contact with petroleum hydrocarbons or coolants such as: gasoline (no benzene. lead); jet fuel; diesel fuel; lubricants and hydraulics' kerosene; asphaltic petroleum hydrocarbon and ethylene glycol.
Acceptable waste at any NTS landfill:
$\square$ Asphalt
Q Metal
$\square$ Wood
$\square$ Paper
$\square$ Rocks / unaltered geologic materials
$\square$ Empty containers
$\square$ Plastic
$\square$ Wire
$\square$ Cable
$\triangle$ Soil
$\square$ Rubber (excluding tires)
$\square$ insulation (non"Asbestosform)
$\square$ Demolition debris
Xl Cement \& concrete
Manufactured items: (swarnp coolers. furniture, rugs, carpet, electronic components, PPE, etc)
Additional waste accepted at the Area 23 Mercury Landfill: $\square$ Office Waste
$\square$ Asbestos $\square$ Friable $\square$ Non-Friable (contact SWO if regulated load)
$\square$ Food Waste
Animal Carcasses
Additional waste accepted at the Area 9 U10c Landfill:
$\square$ Non-friable asbestos
$\square$ Drained automobiles and military vehicles
Light ballasts (contact SWO)
$\square$ Drained fuel filters (gas \& diesel)
Hydrocarbons (contact SWO)
$\square$ Other
Quantity:
Solid fractions from sand/oil/water separators
$\square$ Deconned Underground and Above Ground Tanks

Additional waste accepted at the Area 6 Hydrocarbon Landfill; $\square$ Other

$\square$ Septic sludge $\square$ Rags $\quad \square$ Drained fuel filters (gas \& diesel) $\quad \square$ Crushed non-teme plated oil filters
$\square$ Plants
$\begin{aligned} & \square \text { Soil } \\ & \text { S Sludge from sand/oil/water separators } \square \text { PCBs below 50 parts per million }\end{aligned}$

Initials: (if initialed, no radiological clearance is necessary.)

The above mentioned waste was generated outside of a Controlled Waste Management A knowledge, does not contain radiological materials.

To the best of my knowledge, the waste described above contains only those materials $t$ have verified this through the waste characterization method identified above and a revit and allowable waste items. Lhave contacted Property Management and have verified tha disposal in the landfill.

Print Name: Michael Carselbarye

Signature:

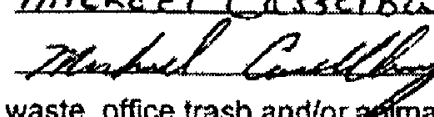

Date: $5 / 18 / 06$

Note: Food waste, office trash and/or afimal carcasses are considered not to contain added radioactivity, and theretore ao not require a radiological clearance.

SWO USE ONLY

Load Weight (net froprscale br estimate):

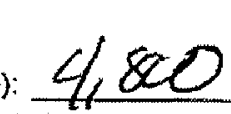
Signature of Certifier: and the has an

Radlological Survey Release for Waste Dispos RCT Inltals

QSR This contalnarlload mests the criteria added man-made radloactive material This containerlload meets the eriteria I Radcon Manual Tabla 4.2 release limity This contalneriond is exempt from sut due to process knowledige and origin. SIGNATURE: $0 \Omega \mathrm{C}$ Bस. 


\section{Bechtel Nevada NTS Landfill Load Verification}

(Waste definitions are avallable on page 2)

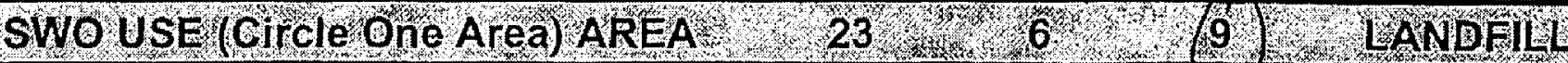

For waste characterization, approval, andlor assistance, contact Solid Waste Operalton (SWO) at 5-7898.

REQUIRED: WASTE GENERATOR INFORMATION

(This form is for rolloffs dump trucks, and other onsite disposal of materials.) $7 / 86$

Waste Generator: Alissa Siluas / Rab Bamect

Location / Origin CAn 528

Trst

cel

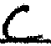

225 Phone Number: 5682

Waste Category: (check one)

Wasto Type:

D. NTS

Commercial

X) Industrial

(check one)

$\square$ Non-Pulrescible

$\square$ Putrescible

(X) FFACO-onsite

Pollution Provention Category: (check one)

Asbestos Containing Maloria

$\square$ FFACO-offsite

Historic DOENV

Pollution Prevention Category: (check one)

$X$ Environtriental management

$\square$ Defense Projects

Method of Characterization: (check one)

X Clean Up

Routine

Prohibited Waste

X] Sampling \& Analysis

Process Knowlodge

$\square$ Contents

at all three NTS tandflils: Wastes (needles, sharps, bloody clothing).

Addiflonal Prohlbited Waste Sewage Siudge; Animal carcasses-, Wet garbage (food waste); and Friable asbestos at the Area 9 U10c Landfill:

\section{REQUIRED: WASTE CONTENTS ALLOWABLE WASTES}

Check all allowabie wastes that are contained within this load:

NOTE: Waste disposed at the Area 6 Hydrocarbon Landfil must have come into contact with peiroleum hydrocarbors or coolenls such es: gasoline (no benzene, lead); jel fuel, diesel fuel; lubricants and hytraulics; kerosene; asphaltic petroloum hydrocarbon; and elhylene glycol
Acceptable waste at any NrS landfill:
$\square$ Paper
$\square$ Rocks / unaltered geologic materials
Empty containers
D Asphalt
$\square$ Metal
$\square$ Wood
D Soll
[] Rubber (excluding tires)
$\square$ Demolition debris
Diastic
$\square$ Wire
$\square$ Cable $\square$ Cloth
$\square$ Insulation (non-Asbestosform)
Cement \& concrete
$\square$ Manufactured items: (swamp coolers, furniture, rugs, carpet, electronic components, PPE, efc.)

Additionat waste accepted at the Area 23 Mercury Landfil: $\square$ Office waste $\square$ Food Waste $\square$ Animal Carcasses

Asbestos: $\square$ Friable $\square$ Non.Friable (contact $S W O$ if regulated load) Quantity:

Additional waste accepted at the Area 9 U10c Landfill:

$\square$ Non-friable asbestos $\quad \square$ Drained automobiles and military vehicles

$\square$ Light ballasts (contact SWO) $\square$ Drained fuel filters (gas \& diesel)

$\square$ Hydrocarbons (contact SWO)

Additional waste accopted at the Area 6 Hycrocarbon Landfill:

$\square$ Septic sludge $\square$ Rags $\square$ Drained fuel filters (gas \& diesel)

Q Plants

$\square$ Sludge from sand/oil/water separators

Initials:

REQUIRED: WASTE GENERATOR SIGNATURE

(If initialed, no radiological clearance is necessary.)

The above mentioned waste was generated outside of a Controlled Wast knowledge, does not contain radiological materials.

To the best of my knowledge, the waste described above contains only site. I have veriffed this through the waste characterization method ident prohibited and allowable waste items.

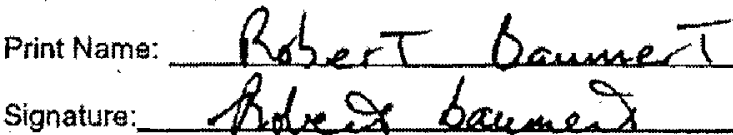
Date: $2 / 19106$

Solid fractions from sand/ollwater separators Deconned Underground and Above Ground Tanks

Note: Food waste, office trash andlor animal carcasses are considered not to contain added radioactivity, and therefore do not require a radiological clearance.

Radlological Survay Reloase for Waste Disposal RCT Initials

This containarhoad meets the criteria

This containerlload meets the cxiteria for

Radcon Manual Tablo 4.2 roloaso Imits.

This containerfload is exempt from survey dus to process knowjedge and origin.

SIGNATURE: LItowath DATE:20006

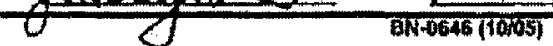


Closure Report - CAU 528

Section: Appendix C

Revision: 0

Date: September 2006

THIS PAGE INTENTIONALLY LEFT BLANK 
Closure Report - CAU 528

Section: Appendix D

Revision: 0

Date: September 2006

\section{APPENDIX D}

\section{USE RESTRICTION DOCUMENTATION}


Closure Report - CAU 528

Section: Appendix D

Revision: 0

Date: September 2006

THIS PAGE INTENTIONALLY LEFT BLANK 


\section{CAU Use Restriction Information}

CAU Number/Description: CAU 528: Polychlorinated Biphenyls Contamination

Applicable CAS Numbers/Descriptions: CAS 25-27-03, Polychlorinated Biphenyls Surface Contamination

Contact (organization/project): $\underline{\text { NNSA/NSO Federal Sub-Project Director }}$

\section{Surveyed Area (UTM, Zone 11, NAD 27, meters):}

\begin{tabular}{|c|c|c|}
\hline AREA I POINTS & NORTHING & EASTING \\
\hline 1 & $4,076,255.352$ & 564401.750 \\
\hline 2 & $4,076,274.231$ & 564410.420 \\
\hline 3 & $4,076,273.130$ & 564413.773 \\
\hline 4 & $4,076,253.884$ & 564404.971 \\
\hline
\end{tabular}

\begin{tabular}{|c|c|c|}
\hline AREA 2 PoINTS & NoRTHING & EASTING \\
\hline 1 & $4,076,266.845$ & 564489.738 \\
\hline 2 & $4,076,268.506$ & 564490.001 \\
\hline 3 & $4,076,284.520$ & 564504.361 \\
\hline 4 & $4,076,268.908$ & 564502.378 \\
\hline
\end{tabular}

\begin{tabular}{|c|c|c|}
\hline ARE A 3 POINTS & NORTHING & EASTING \\
\hline 1 & 4076228.504 & 564498.459 \\
\hline 2 & 4076236.208 & 564512.742 \\
\hline 3 & 4076219.565 & 564522.538 \\
\hline 4 & 4076206.434 & 564522.170 \\
\hline 5 & 4076206.405 & 564511.947 \\
\hline
\end{tabular}

\begin{tabular}{|c|c|c|}
\hline AREA 4 POINTS & NORTHING & EASTING \\
\hline 1 & 4076244.039 & 564386.792 \\
\hline 2 & 4076252.899 & 564410.607 \\
\hline 3 & 4076194.435 & 564409.275 \\
\hline 4 & 4076192.305 & 564391.232 \\
\hline
\end{tabular}

\begin{tabular}{|c|c|c|}
\hline AREA 5 POINTS & NORTHING & EASTING \\
\hline 1 & 4076214.119 & 564546.184 \\
\hline 2 & 4076224.533 & 564554.739 \\
\hline 4 & 4076218.759 & 564561.367 \\
\hline
\end{tabular}




\begin{tabular}{|c|c|c|}
\hline AREA 6 POINTS & NORTHING & EASTING \\
\hline 1 & 4076153.528 & 564377.835 \\
\hline 2 & 4076151.154 & 564383.417 \\
\hline 3 & 4076139.374 & 564379.161 \\
\hline 4 & 4076139.945 & 564373.795 \\
\hline
\end{tabular}

\begin{tabular}{|c|c|c|}
\hline AREA 8 POINTS & NORTHING & EASTING \\
\hline 1 & 4076114.864 & 564342.621 \\
\hline 2 & 4076126.339 & 564356.029 \\
\hline 3 & 4076124.353 & 564375.529 \\
\hline 4 & 4076088.791 & 564366.929 \\
\hline
\end{tabular}

\begin{tabular}{|c|c|c|}
\hline AREA 9 POINTS & NoRTHING & EASTING \\
\hline 1 & 4076114.563 & 564545.308 \\
\hline 2 & 4076129.603 & 564557.896 \\
\hline 3 & 4076122.576 & 564567.486 \\
\hline 4 & 4076108.025 & 564557.964 \\
\hline
\end{tabular}

\begin{tabular}{|c|c|c|}
\hline AREA 10 POINTS & NORTHING & EASTING \\
\hline 1 & 4076073.019 & 564539.839 \\
\hline 2 & 4076059.056 & 564556.677 \\
\hline 3 & 4076045.458 & 564554.428 \\
\hline 4 & 4076058.992 & 564539.131 \\
\hline
\end{tabular}

\begin{tabular}{|c|c|c|}
\hline AREA 11 POINTS & NORTHING & EASTING \\
\hline 1 & 4076192.305 & 564391.232 \\
\hline 2 & 4076194.435 & 564409.275 \\
\hline 3 & 4076149.890 & 564410.614 \\
\hline 4 & 4076139.646 & 564414.009 \\
\hline 5 & 4076122.292 & 564413.955 \\
\hline 6 & 4076117.756 & 564410.905 \\
\hline 8 & 4076109.029 & 564410.941 \\
\hline 9 & 4076109.150 & 564402.952 \\
\hline 10 & 4076096.060 & 564404.668 \\
\hline
\end{tabular}

\begin{tabular}{|c|c|c|}
\hline AREA 12 POINTS & NORTHING & EASTING \\
\hline 1 & 4076266.265 & 564432.786 \\
\hline 2 & 4076271.006 & 564444.661 \\
\hline 3 & 4076264.989 & 564444.644 \\
\hline 4 & 4076258.453 & 564434.961 \\
\hline
\end{tabular}

Survey Date: $\underline{06 / 29 / 2006}$ Survey Method (GPS, etc): GPS 
Site Monitoring Requirements: Visual Inspections

Required Frequency (quarterly, annually?): Annually

If Monitoring Has Started, Indicate last Completion Date: N/A

\section{Use Restrictions}

The future use of any land related to this Corrective Action Unit (CAU), as described by the above surveyed location, is restricted from any DOE or Air Force activity that may alter or modify the containment control as approved by the state and identified in the CAU Closure Report or other CAU documentation unless appropriate concurrence is obtained in advance.

Comments: See the Closure Report for additional information on the condition of the site(s) and any monitoring and/or inspection requirements.

Submitted By: Sabin Curtis_Date: $9120 / 06$

cc with copy of survey map (paper and digital (dgn) formats):

CAU Files (2 copies) 


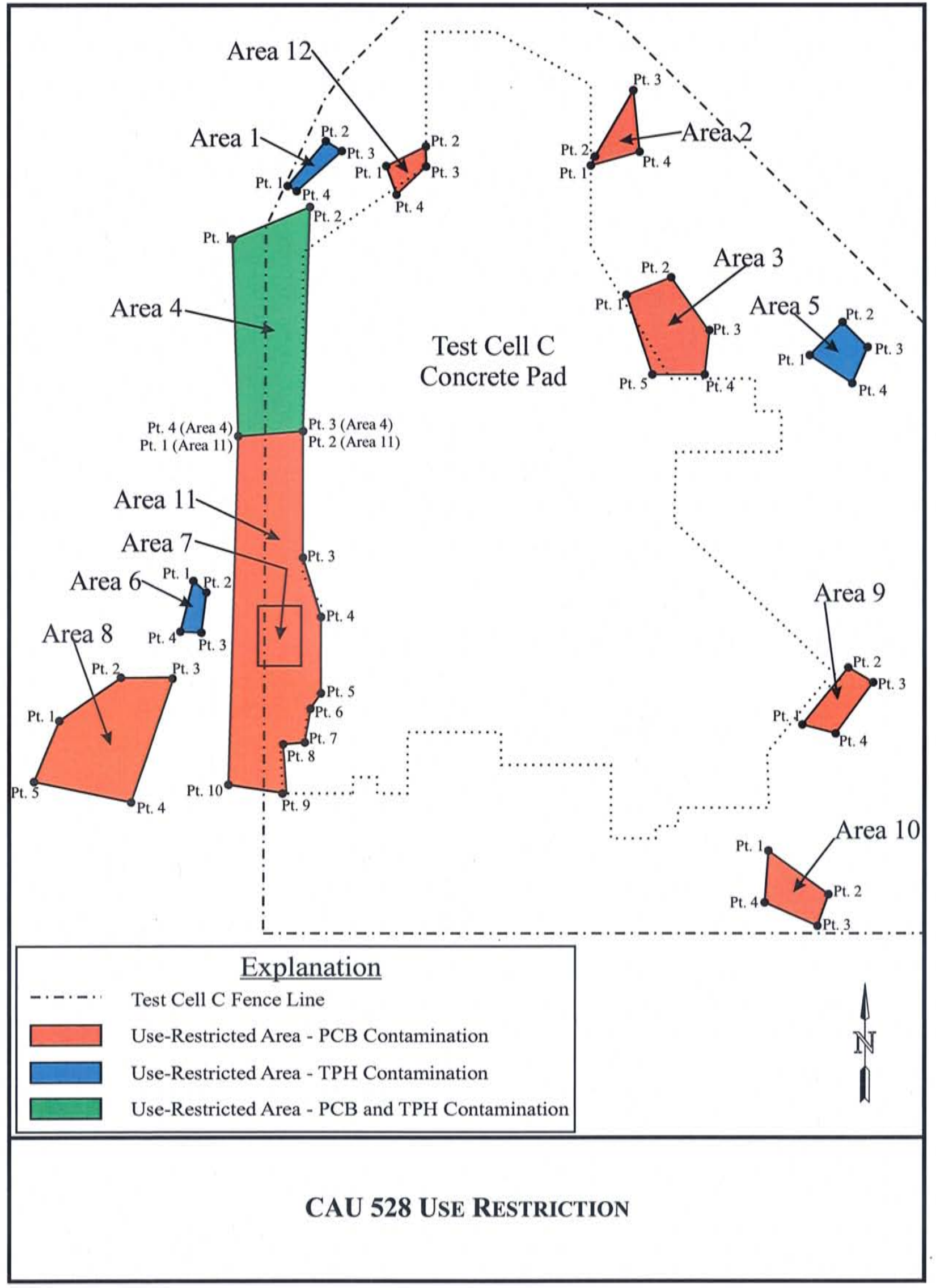


Closure Report - CAU 528

Section: Appendix E

Revision: 0

Date: September 2006

\section{APPENDIX E}

\section{SITE CLOSURE PHOTOGRAPHS}


Closure Report - CAU 528

Section: Appendix E

Revision: 0

Date: September 2006

THIS PAGE INTENTIONALLY LEFT BLANK 


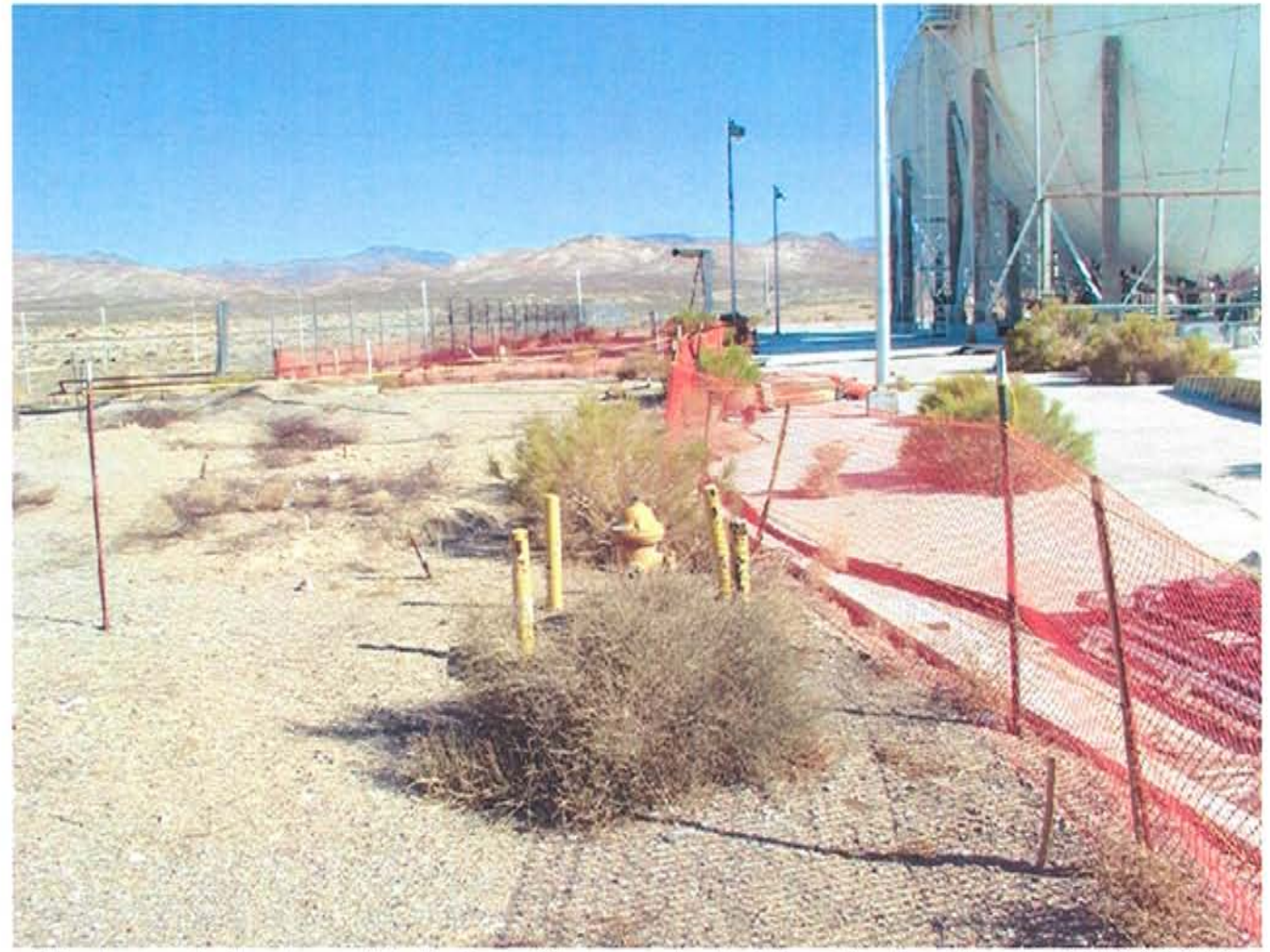

Photograph 1: Area 7A Before Closure Activities, Facing North, 12/04/2002

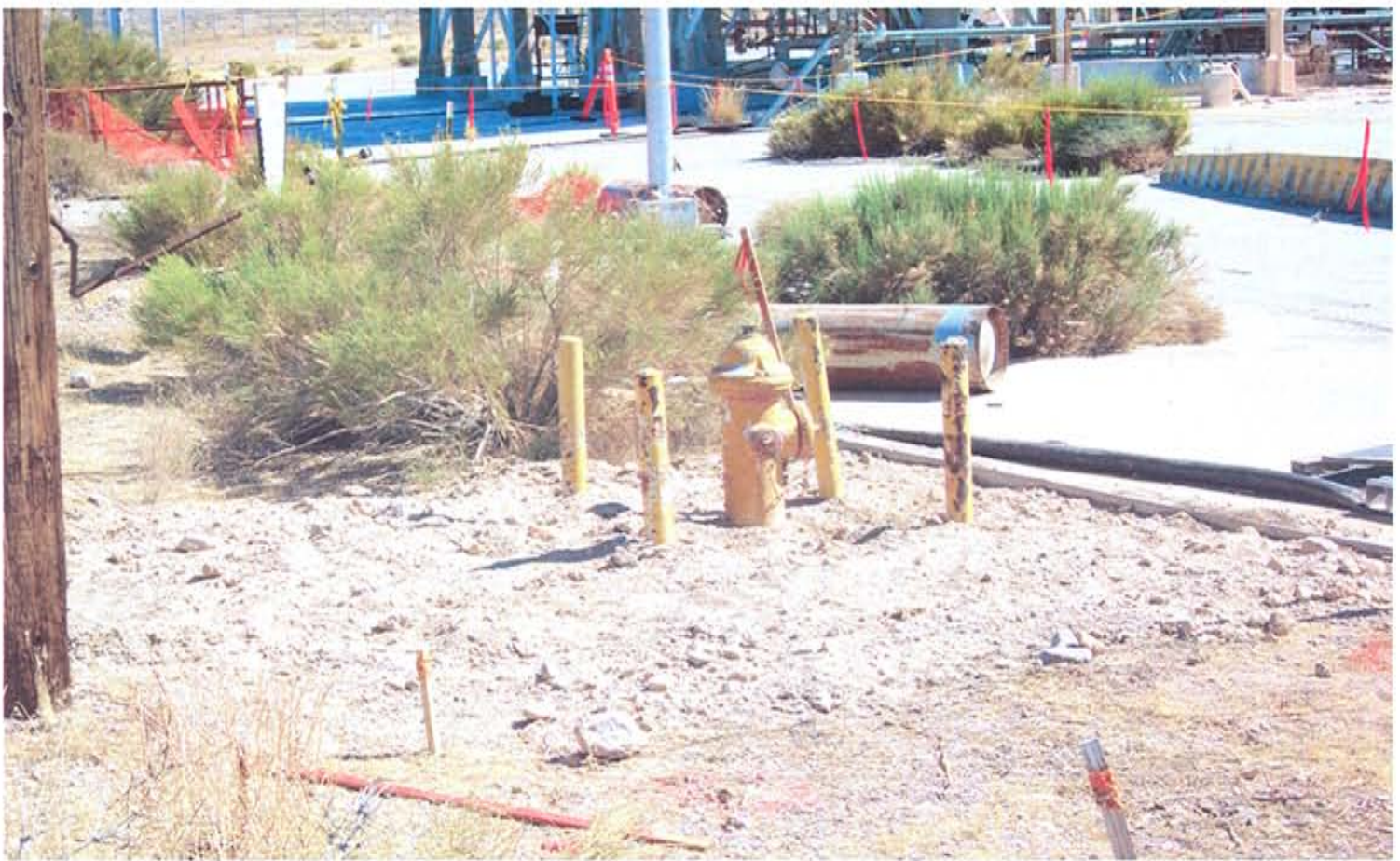

Photograph 2: Area 7A After Closure Activities, Facing Northeast, 06/29/2006 


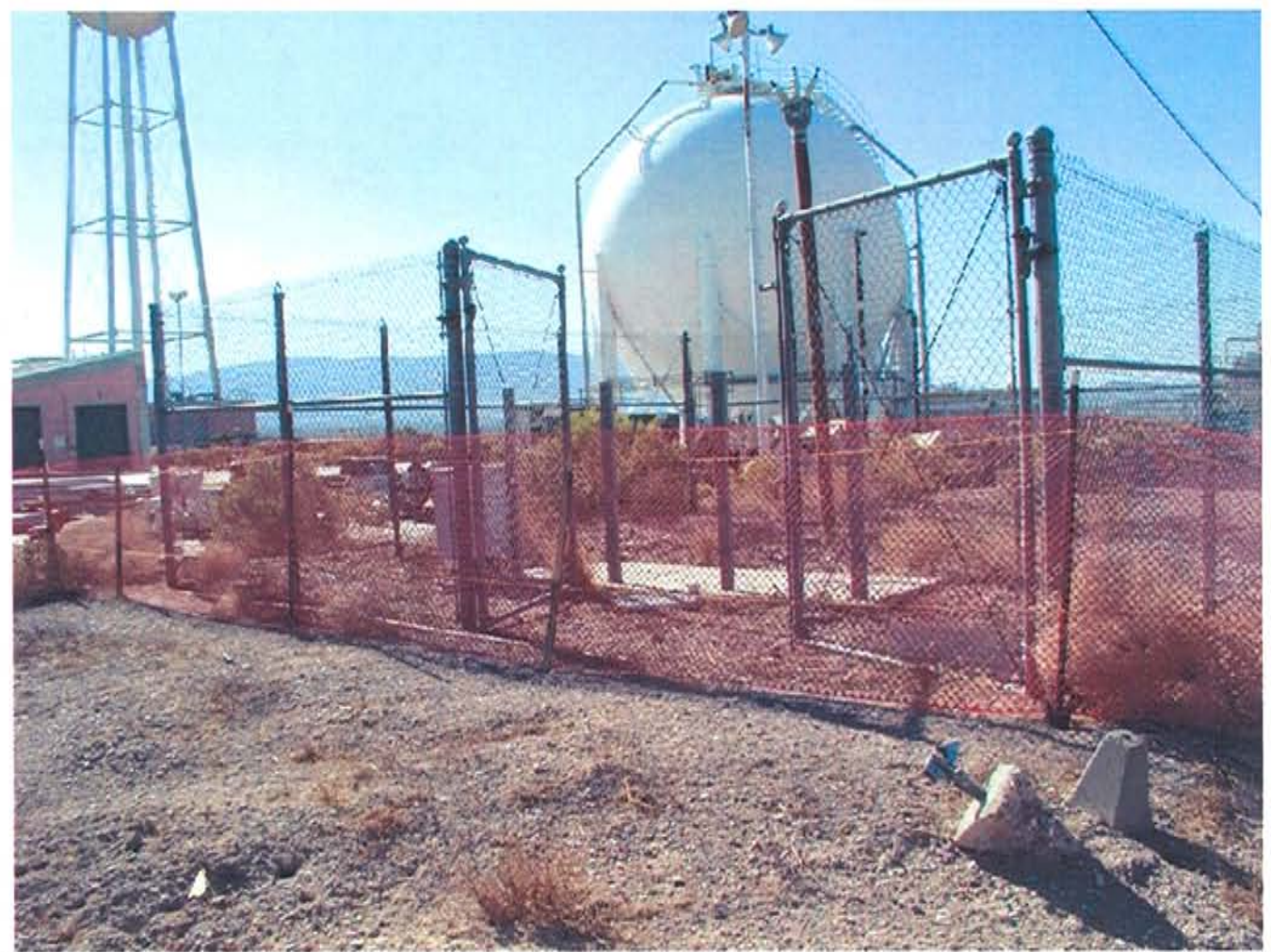

Photograph 3: Area 7B Before Closure Activities, Facing Southeast, 12/04/2002

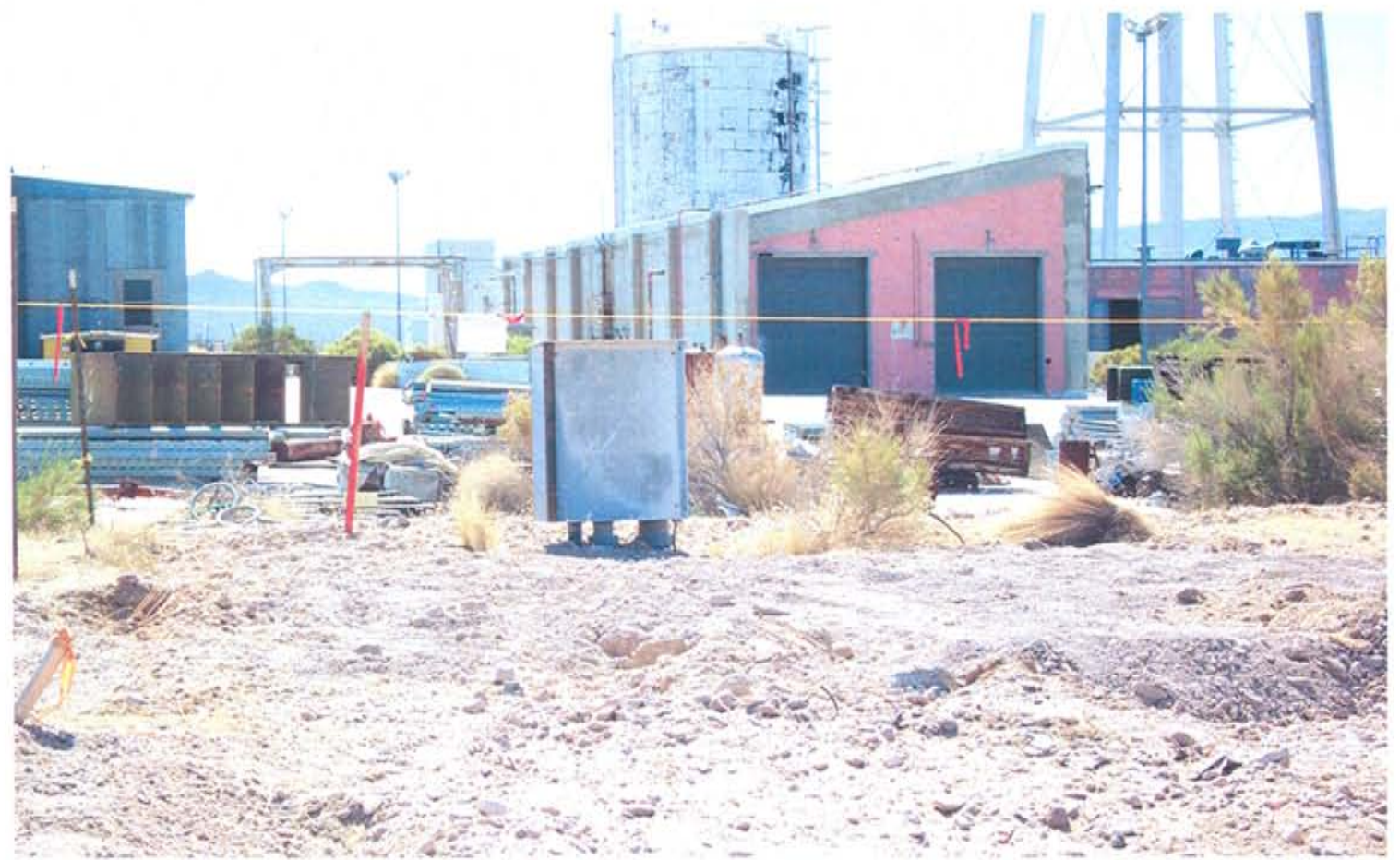

Photograph 4: Area 7B After Closure Activities, Facing East, 06/29/2006 


\section{Photograph Log}

\begin{tabular}{|c|c|c|l|}
\hline $\begin{array}{c}\text { PHotograpH } \\
\text { Number }\end{array}$ & DATE & Perspective & \multicolumn{1}{|c|}{ DescriPtion } \\
\hline 1 & $12 / 04 / 2002$ & Facing North & Area 7A Before Closure Activities \\
\hline 2 & $06 / 29 / 2006$ & Facing Northeast & Area 7A After Closure Activities \\
\hline 3 & $12 / 04 / 2002$ & Facing Southeast & Area 7B Before Closure Activities \\
\hline 4 & $06 / 29 / 2006$ & Facing East & Area 7B After Closure Activities \\
\hline
\end{tabular}


Closure Report - CAU 528

Section: Appendix E

Revision: 0

Date: September 2006

THIS PAGE INTENTIONALLY LEFT BLANK 
Closure Report - CAU 528

Section: Library Distribution List

Revision: 0

Date: September 2006

\section{LIBRARY DISTRIBUTION LIST}


Closure Report - CAU 528

Section: Library Distribution List

Revision: 0

Date: September 2006

THIS PAGE INTENTIONALLY LEFT BLANK 
U.S. Department of Energy

National Nuclear Security Administration

Nevada Site Office

Technical Library

P.O. Box 98518, M/S 505

Las Vegas, NV 89193-8518

U.S. Department of Energy

Office of Scientific and Technical Information

P.O. Box 62

Oak Ridge, TN 37831-0062

Southern Nevada Public Reading Facility

c/o Nuclear Testing Archive

P.O. Box 98521 , M/S 400

Las Vegas, NV 89193-8521

Manager, Northern Nevada FFACO

Public Reading Facility

c/o Nevada State Library \& Archives

Carson City, NV 89701-4285
1 (Uncontrolled)

1 (Uncontrolled, electronic copy)

2 (Uncontrolled, electronic copies)

1 (Uncontrolled, electronic copy) 
Closure Report - CAU 528

Section: Library Distribution List

Revision: 0

Date: September 2006

THIS PAGE INTENTIONALLY LEFT BLANK 